\title{
Implications of the Newark Supergroup-based astrochronology and geomagnetic polarity time scale (Newark-APTS) for the tempo and mode of the early diversification of the Dinosauria
}

\author{
Paul E. Olsen ${ }^{1}$, Dennis V. Kent ${ }^{1,2}$ and Jessica H. Whiteside ${ }^{3}$ \\ ${ }^{1}$ Lamont-Doherty Earth Observatory of Columbia University, Palisades, New York, NY 10964 USA \\ Email: polsen@1deo.columbia.edu \\ ${ }^{2}$ Department of Earth and Planetary Sciences, Rutgers University, Piscataway, NJ 08854 USA \\ Email: dvk@rci.rutgers.edu \\ ${ }^{3}$ Department of Geological Sciences, Brown University, Providence, RI 02912 USA \\ Email: Jessica_Whiteside@brown.edu
}

\begin{abstract}
The Newark-APTS established a high-resolution framework for the Late Triassic and Early Jurassic. Palaeomagnetic polarity correlations to marine sections show that stage-level correlations of continental sequences were off by as much as 10 million years. New U-Pb ages show the new correlations and the Newark basin astrochronology to be accurate. Correlation of Newark-APTS to the Chinle Formation/Dockum Group, Glen Canyon Group, Fleming Fjord Formation and Ischigualasto Formation led to the following conclusions: (1) there are no unequivocal Carnian-age dinosaurs; (2) the Norian Age was characterised by a slowly increasing saurischian diversity but no unequivocal ornithischians; (3) there was profound Norian and Rhaetian continental provinciality; (4) the classic Chinle-, Germanic- and Los Colorados-type assemblages may have persisted to the close of the Rhaetian; (5) the distinct genus-level biotic transition traditionally correlated with the marine Carnian-Norian is in fact mid-Norian in age and within published error of the Manicouagan impact; (6) the end-Triassic marine and continental extinctions as seen in eastern North America were contemporaneous; and (7) compared to Triassic communities, Hettangian and Sinemurian age terrestrial communities were nearly globally homogenous and of low diversity. Consequently, the complex emerging picture of dinosaur diversification demands biostratigraphically-independent geochronologies in each of the faunally-important regions.
\end{abstract}

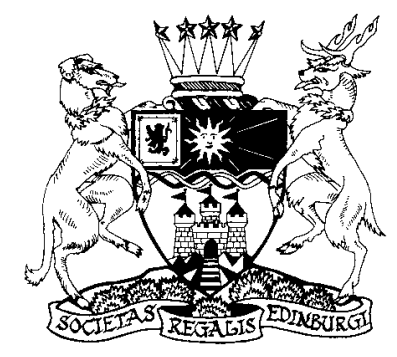

KEY WORDS: Chinle, cyclostratigraphy, dinosaurs, Early Jurassic, Fleming Fjord, geochronology, Glen Canyon, Ischigualasto, Late Triassic

Understanding of the origin and diversification of the Dinosauria has been plagued by a lack of precision and accuracy in both the relative and absolute ages of the geographically dispersed deposits in which bones and traces of early dinosaurs and their relatives are found. This in turn has led to extremely divergent views of the processes involved with the ascent of the dinosaurs to ecological dominance - perhaps the most striking feature of the entire Mesozoic (e.g., Langer et al. 2009; Brusatte et al. 2010). Fundamental to this problem has been the lack of a reliable time scale for the Late Triassic and Early Jurassic. Published compilations of radioisotopic ages (e.g. Harland et al. 1990; Gradstein \& Ogg 1996; Gradstein et al. 2005), despite valiant efforts, have unfortunately not helped because of a paucity of dates in critical intervals, dates that are compromised internally, or dates from strata which themselves are poorly registered to the marine standard stages. Over-reliance on low-resolution biostratigraphy (both stratigraphically and taxonomically) has further compounded problems by obscuring real faunal differences in time and space (Irmis et al. 2010).

One of the principal goals of the Newark Basin Coring Project (NBCP), 20 years old in 2010, was the development of an astronomically calibrated Late Triassic geomagnetic polarity time scale that had the potential to be exportable globally via magnetostratigraphy. Additional progress in the magnetic polarity stratigraphy of Early Jurassic age continental Newark Supergroup strata of the Hartford basin and Triassic-Jurassic marine sections and major advances in $\mathrm{U}-\mathrm{Pb}$ geochronology have now made it possible to realise the potential of the Newark Supergroup-Astronomically-calibrated geomagnetic Polarity Time Scale (Newark-APTS) for placing early dinosaur assemblages in a high-resolution temporal context. This paper is a review of that progress and its implications.

\section{The Newark-APTS}

The NBCP, funded by the US National Science Foundation (1990-1994), recovered the entire Triassic age sedimentary sequence, as well as a small part of the overlying basalt flows and interbedded sediments in the central part of the Newark rift basin (Fig. 1) in seven $\sim 1$ to $\sim 1.5 \mathrm{~km}$ continuous cores (Kent et al. 1995; Olsen et al. 1996a). The Newark basin strata were targeted because of their great thickness in unquestioned superposition, promising high accumulation-rates, 


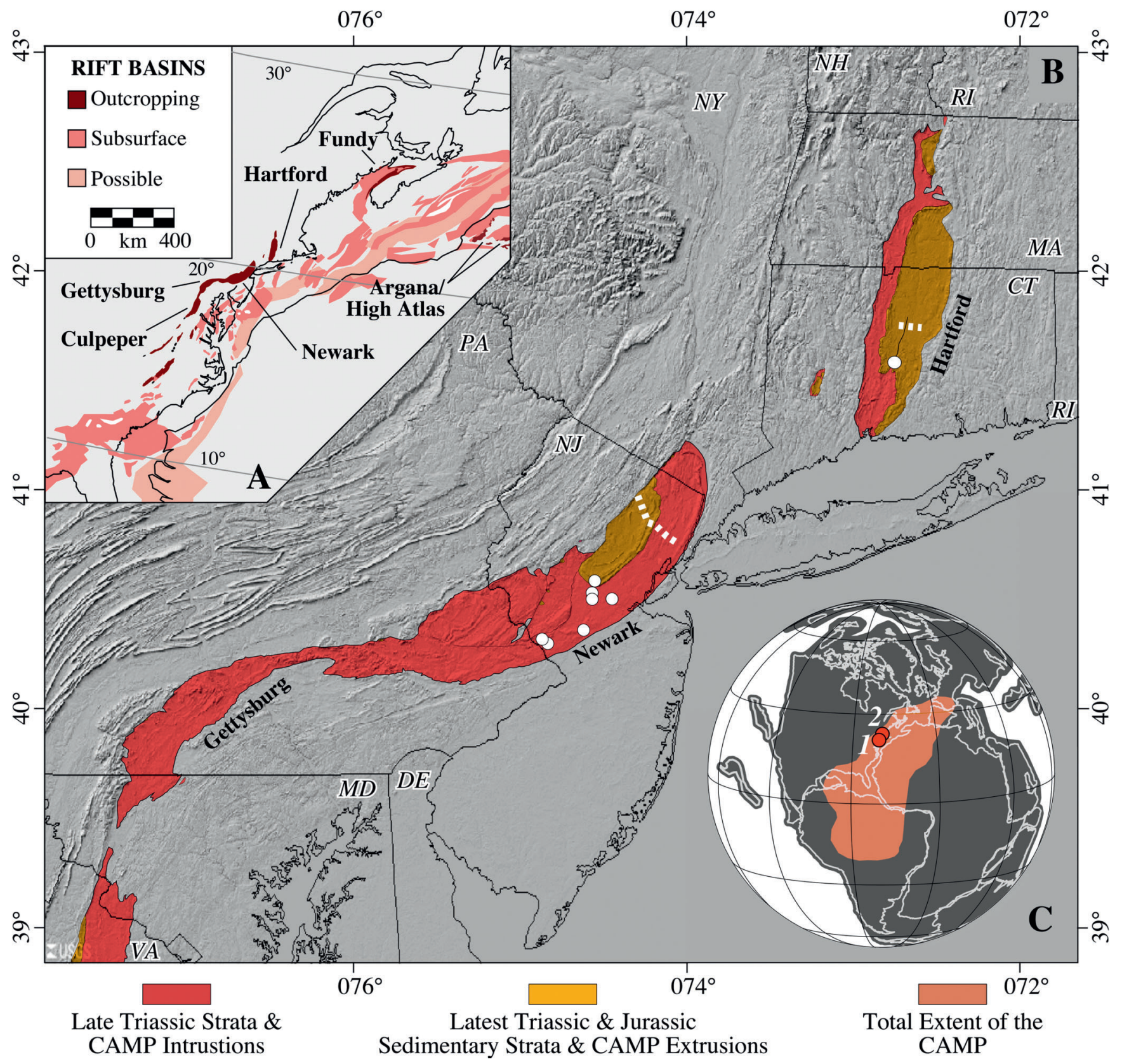

Figure 1 Location of the cores forming the basis of the Newark basin astrochronology and geomagnetic polarity time scale (Newark-APTS): (A) Index map of the Early Jurassic rifting zone in central Pangea in earliest Jurassic coordinates (latitudes from Kent \& Tauxe 2005; map from Whiteside et al. 2007); (B) Locations of cores within the Newark and Hartford basins with present day latitudes and longitudes on shaded relief map (USGS National Map Viewer): white dots in Newark basin show positions of the seven Newark Basin Coring Project (NBCP) cores, while the thick white dashed line indicates the Passaic River Diversion Tunnel Army Corps of Engineers (ACE) core transect; white dot in the Hartford basin shows position of the Silver Ridge B-1 cores, while the thick white dashed line indicates the Park River Flood Control Army Corps of Engineers (Park River) core transect. Note that the numerous outcrop locations used in the construction and testing of the Newark and Hartford basin composite sections are not shown (see Olsen et al. 1996a and Kent \& Olsen 2008 for these). Abbreviations of states: $C T=$ Connecticut; $D E=$ Delaware; $M A=$ Massachusetts; $M D=$ Maryland; $N H=$ New Hampshire; $N J=$ New Jersey; $N Y=$ New York; $P A=$ Pennsylvania; $R I=$ Rhode Island; $V A=$ Virginia; (C) Earliest Jurassic plate configuration showing distribution of the Central Atlantic Magmatic Province (CAMP) (based on latitudes from Kent \& Tauxe 2005, based on map from Whiteside et al. 2010, based in turn on base map provided by C. Scotese). Locations on map of Pangea: $1=$ Newark basin; $2=$ Hartford basin.

high-resolution records, and because of the presence of what had been interpreted as permeating astronomically-controlled lacustrine sedimentary cycles (Van Houten 1962; Olsen 1986). Added to this were a large series of short continuous cores ( $\sim 100 \mathrm{~m}$ each) collected by Army Corps of Engineers (ACE cores) for the Passaic River Diversion Tunnel that covered the entire series of basalt flows and most of the overlying synrift strata (Fedosh \& Smoot 1988; Olsen et al. 1996b). The large stratigraphic overlap among cores allowed production of a roughly $5800 \mathrm{~m}$-thick composite stratigraphy, tested by magnetic polarity stratigraphy, well logs and high-resolution lithostratigraphy (Fig. 2). Most of the section recovered proved to be lacustrine and marginal lacustrine, with the promised lithologic cycles (Fig. 3) caused by variations in the Earth's orbit (Olsen \& Kent 1996). Augmented by core and outcrop sections from the Hartford basin continuing well into the Early Jurassic (Kent \& Olsen 2008), this cyclicity forms the basis of the Newark-APTS. 


\section{FORMATIONS / \\ BASINS \\ MEMBERS}

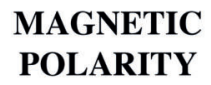

MAGNETIC

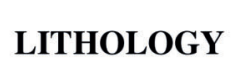

PALYNO-

HARTFORD NEWARK

\begin{tabular}{|c|c|c|}
\hline HARTFORD & NEWARK & $5-1$ \\
\hline & & Stony Brook \\
\hline RTLAND & BOONTON & Mittinegue \\
\hline & & S. Hadley Falls \\
\hline & & Park River \\
\hline $\begin{array}{l}\text { ampton } \\
\text { Basalt } \\
\text { Eapata }\end{array}$ & $\begin{array}{c}\text { Hook Mtt. } \\
\text { Basalt }\end{array}$ & Smiths Ferry \\
\hline
\end{tabular}

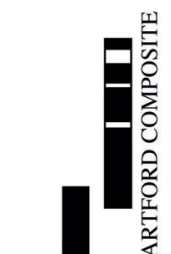

meters

FLORAL GEOLOGIC

GEOLOGIC

ZONES AGE (1996)

AGE (2010)

\begin{tabular}{|c|c|c|}
\hline $\begin{array}{c}\text { Basalt } \\
\text { East } \\
\text { Berlin Fm. }\end{array}$ & $\begin{array}{c}\text { Basalt } \\
\text { Towaco Fm. }\end{array}$ & \\
\hline $\begin{array}{c}\text { Holyoke } \\
\text { Basalt }\end{array}$ & $\begin{array}{c}\text { Preakness } \\
\text { Basalt }\end{array}$ & \\
\hline Shuttle & Feltville Fm. & \\
\hline$\frac{\text { Meadow Fm }}{\text { Talcott Fm. }}$ & $\begin{array}{c}\text { Orange Mt. } \\
\text { Basalt. }\end{array}$ & Exeter Twp. \\
\hline & & \begin{tabular}{|c|} 
Pine Ridge \\
TT \\
\end{tabular} \\
\hline
\end{tabular}

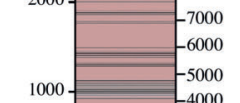

leet

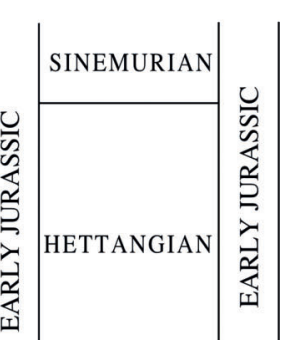

NEW
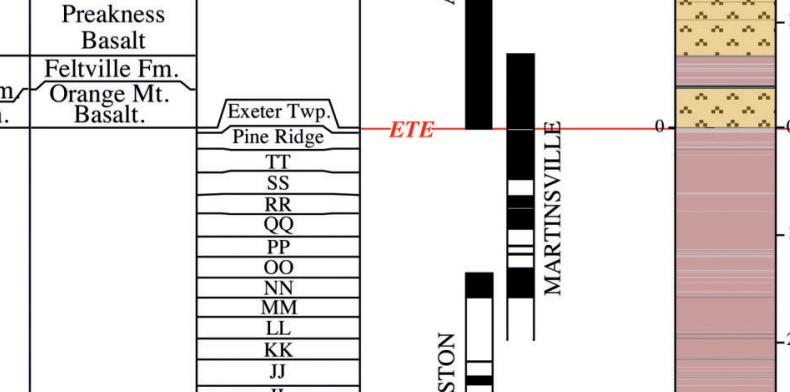

PASSAIC

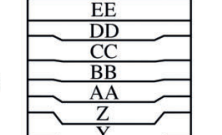

总

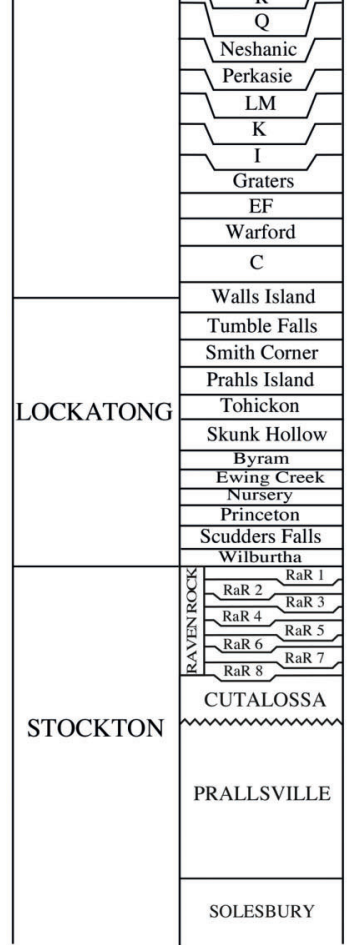

年

$\left.\right|_{-1000} ^{\infty}$
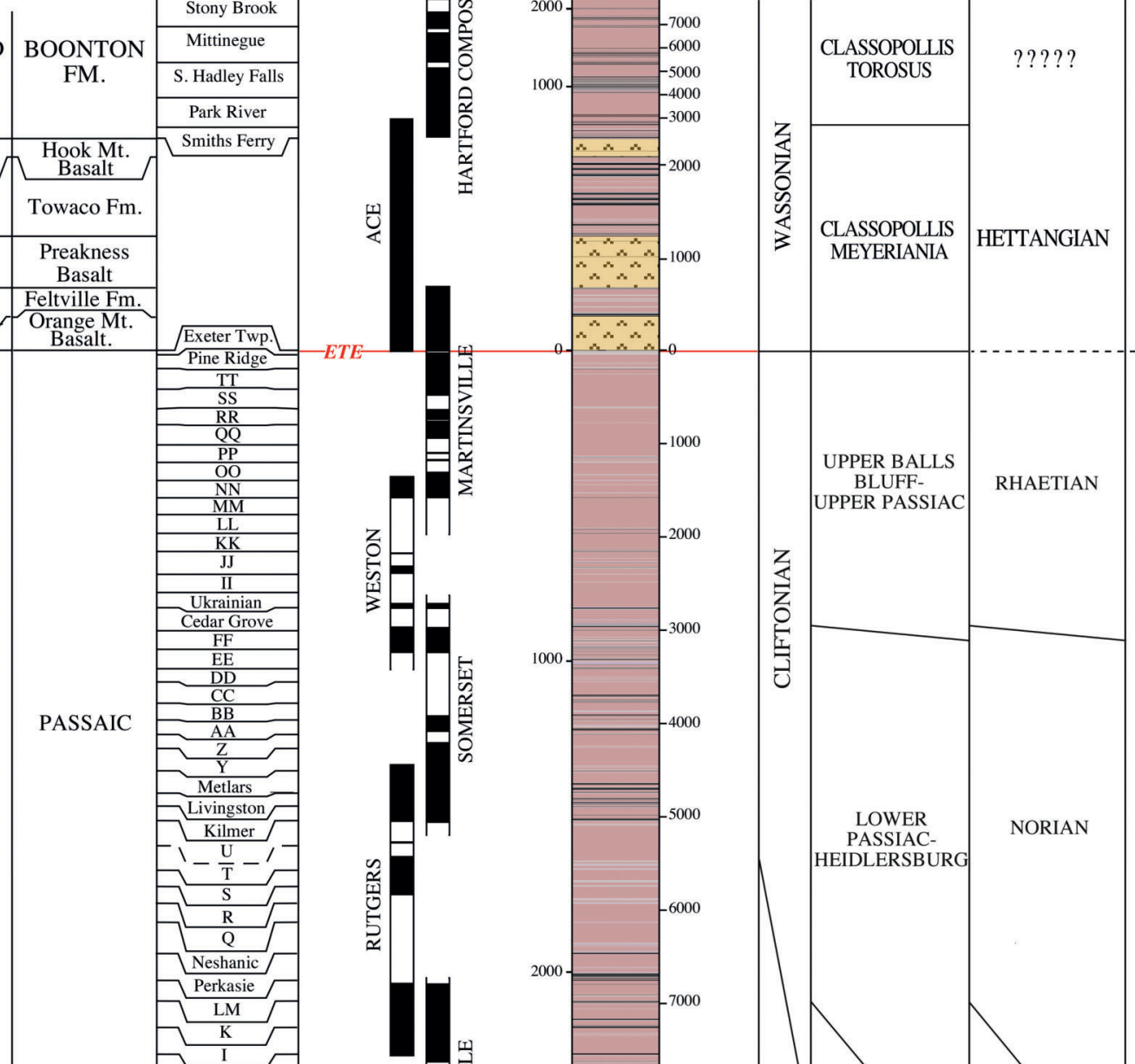

表
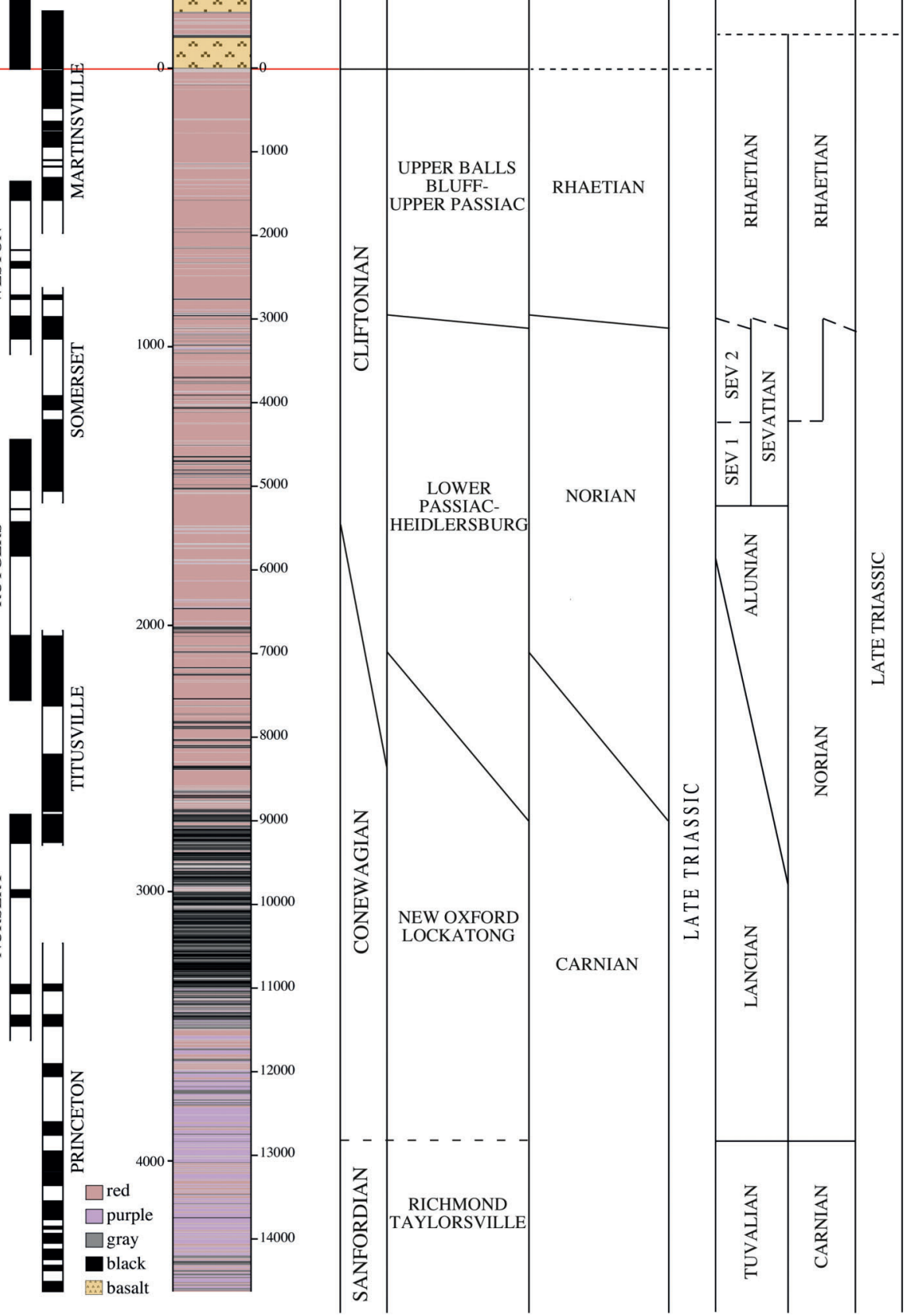

Figure 2 Lithostratigraphy of the Newark basin based on the Newark basin coring project with the ages as they are understood in 1996 and in the Newark-APTS 2010. Adapted from Olsen et al. (1996a) and Olsen \& Whiteside (2008).

Olsen et al. (1996a) termed lithological cycles with a strong thickness mode at $\sim 60 \mathrm{~m}$ prevalent above the basal and largely fluvial Stockton Formation and below the basalts as the McLaughlin cycles (Fig. 3) and designated each of them lithostratigraphic members, the boundaries of which are defined by prominent beds of distinctive lithology. Olsen \& Kent (1996) argued that McLaughlin cycles were paced by the $\sim 400 \mathrm{kyr}$ (abbreviations for time as recommended by Aubry et al. 2009) eccentricity cycle, which at the time was generally thought to have a period of about $413 \mathrm{kyr}$ (Berger 1977; Berger 


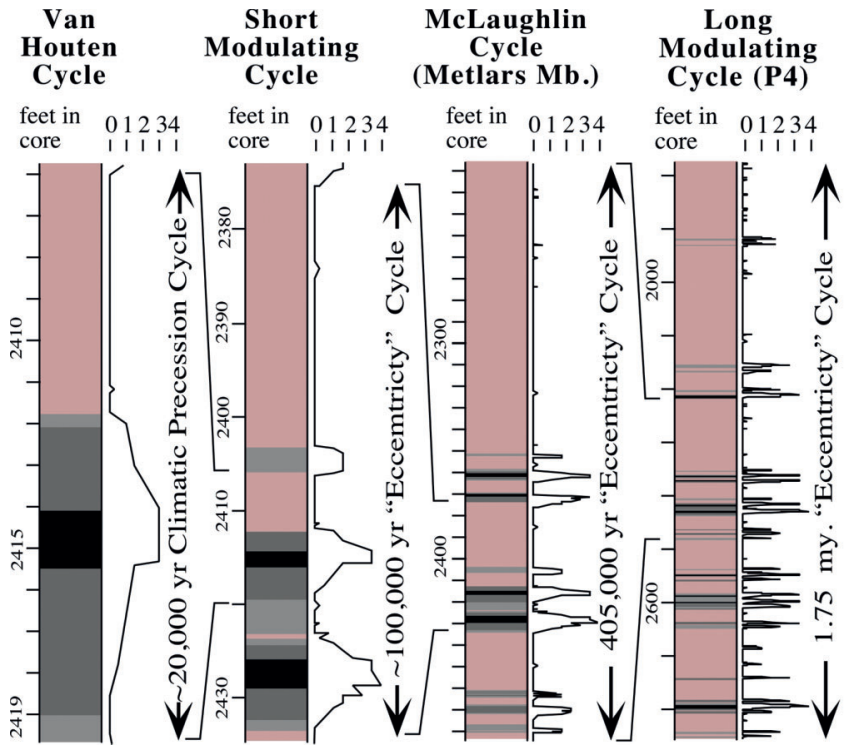

Figure 3 Newark basin hierarchy of lithological cycles with interpreted durations. Adapted from Olsen et al. 1996a.

\& Loutre 1990). Kent et al. (1995) used these members, each corresponding to a McLaughlin cycle, as the basis of the first iteration of the Newark-APTS (Newark-APTS 1995), adding on the cyclostratigraphically calibrated ACE cores analysed by Olsen et al. (1996b) (Figs 3, 4). Kent \& Olsen (1999) also extended the methodology into the marginal lacustrine and fluvial Raven Rock Member of the upper Stockton Formation based on colour variations, identifying eight additional cycles corresponding to McLaughlin cycles. They also modified the time scale by using a $404 \mathrm{kyr}$ period cycle based on $20 \mathrm{Myr}$ of the La90 solution (Laskar 1990) for the duration of the McLaughlin cycles, as opposed to $413 \mathrm{kyr}$ from Berger (1977) (Fig. 4) to produce the second iteration of the time scale (Newark-APTS 1999A).

Kent et al. (1995) recognised 59 magnetozones in the composite section based on a sampling density of about one sample per $20 \mathrm{kyr}$ ( $\sim 1$ sample per $3 \mathrm{~m}$ in Newark-APTS 1995. Only polarity zones with two or more successive samples with the same polarity were recognised in the composite section of magnetozones. In Kent \& Olsen (1999), 35 polarity transitions out of 60 (E13n to E23r) were resampled at a density of about one sample per $2 \cdot 2 \mathrm{kyr}(\sim 1$ sample per $0.3 \mathrm{~m})$. Based on the astrochronology, the duration of the polarity transitions was about $7 \cdot 9 \pm 4 \cdot 5 \mathrm{kyr}$, comparable to that seen in the Pleistocene. Kent \& Olsen (1999) also modified the designation of the youngest polarity zone (E23n) by splitting off E23n.2n as a separate magnetozone E24n, spanning the extrusive zone and overlying Boonton Formation, and giving greater emphasis to the thin but important reverse polarity interval E23n.1r, which was designated E23r (Fig. 4).

The only suitably precise radioisotopic dates directly relevant to the Newark basin for Newark-APTS 1995/1999A were ${ }^{40} \mathrm{Ar} /{ }^{39} \mathrm{Ar}$ and $\mathrm{U}-\mathrm{Pb}$ ages from the presumed feeder of some of the basalt flows, the Palisade sill $(202 \cdot 2 \pm 1 \cdot 3 \mathrm{Ma}$, Sutter 1988; 200.9 $\pm 1 \cdot 0$ Ma, Dunning \& Hodych 1990), averaging about $201.6 \mathrm{Ma}$. Assuming that this was close to the middle of the time of eruption (the Palisade sill was thought to be a feeder to the Preakness Basalt: Ratcliffe 1988; see below) and that the Feltville Formation and Orange Mountain Basalt might add on another $0.5 \mathrm{Myr}$ allowed the Newark-APTS 1995/1999A floating astronomical time scales to be pinned to the radioisotopically calibrated time scale at $202 \mathrm{Ma}$ (after rounding to the nearest $0.5 \mathrm{Myr}$ ) for the Triassic-Jurassic boundary.
Pollen and spore assemblages provided a basis for correlation to the marine stages for Newark-APTS 1995/1999A (Cornet 1977, 1993; Cornet \& Olsen 1985; Fowell \& Olsen 1993; Fowell et al. 1994; Fowell \& Traverse 1995) via normal literature-based correlation webs. Three stage boundaries were identified within Newark basin sections corresponding to Cornet's three palynological assemblages. The oldest floral boundary in the Newark basin, between the New OxfordLockatong and Lower Passaic-Heidlersburg palynofloral zones, was correlated to the Carnian-Norian marine boundary, based largely on the presence of characteristic Carnian and Norian taxon Camerosporites pseudoverrucatus in the New Oxford-Lockatong palynoflora and its absence from the overlying Lower Passaic-Heidlersburg palynofloral zone. The boundary between the Lower Passaic-Heidlersburg and Upper Balls Bluff-Upper Passaic palynofloral zones was equated with the Norian-Rhaetian marine boundary largely because of the increase in Classopollis (Corollina) spp., including the first appearance of Classopollis torosus, and the first appearance of Granulopercultatipollis rudis in the Upper Balls Bluff-Upper Passaic palynofloral zone.

In contrast, the boundary between the Upper Balls BluffUpper Passaic and overlying Classopollis meyeriana palynofloral zones is more dramatic, involving the last appearances of many pollen and spore taxa characteristic of the Triassic and the abrupt appearance of a flood of Classopollis meyeriana. The first appearance of the characteristic Early Jurassic taxon Convolutispora klukiforma occurs within this zone, which extends through the entire basalt flow interval. Thus, the Upper Balls Bluff-Upper Passaic and Classopollis meyeriana palynofloral zones were correlated to the Triassic-Jurassic boundary as it was loosely recognised in Europe. These palynological correlations in Newark-APTS1995/1999A agreed for the most part with contemporaneous correlations based on tetrapod biochronology (Olsen \& Sues 1986; Lucas 1993; Lucas \& Huber, 1993; Lucas et al. 1998).

Olsen \& Kent (1999) introduced a refinement of the astronomical calibration of the Newark-APTS 1999A. The member boundaries defined by Olsen et al. (1996a) and used by Newark-APTS 1995/1999 are subjectively picked distinctive lithological units and do not correspond in a uniform way to the continuously varying modulators of the precession-scale variability. The age model based on boundaries between individual members (Newark-APTS 1995/1999a) was not suitable for a quantitative tuning of the lake level sequence time series analysis. Instead, Olsen \& Kent (1999) used smoothed and filtered sedimentary facies and colour curves to numerically tune the section to a pure $404 \mathrm{kyr}$ sinusoid (Fig. 4) to produce the third iteration, Newark-APTS 1999B. Essentially the same timescale was used without detailed explanation in Olsen (1997). This different tuning procedure produces no change in total duration from Newark-APTS 1999A, but does change the age of some of the polarity boundaries, although only by less than a small fraction of a percent. Newark-APTS 1999B was modified by Olsen et al. (2003), with the addition of several $404 \mathrm{kyr}$ cycles and associated magnetic polarity zones based on an analysis of cores and outcrops in the Portland Formation of the Hartford basin (Kent \& Olsen 1999; Olsen et al. 2002b).

Until 2003, the only link between the Newark-APTS and the marine standard stages was palynology and to a lesser extent vertebrate palaeontology; previous magnetostratigraphic correlations of the Newark to marine sections were mutually inconsistent (e.g. Gallet et al. 2000, 2003) and radioisotopic ages were far too sparse. However, Muttoni et al. (2004) and Channell et al. (2003) independently used magnetostratigraphy to correlate Tethyan marine sections in Italy and Slovakia, 

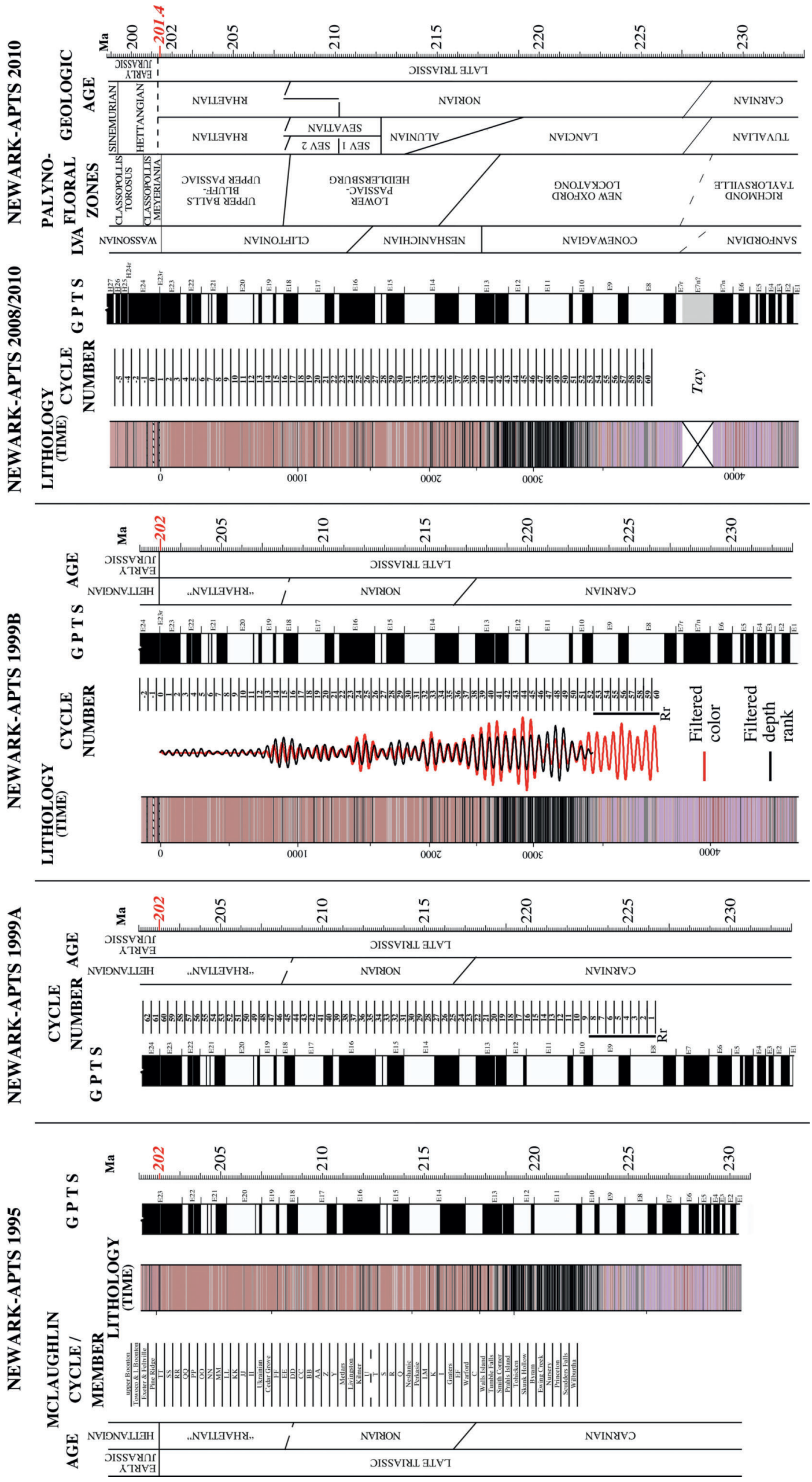


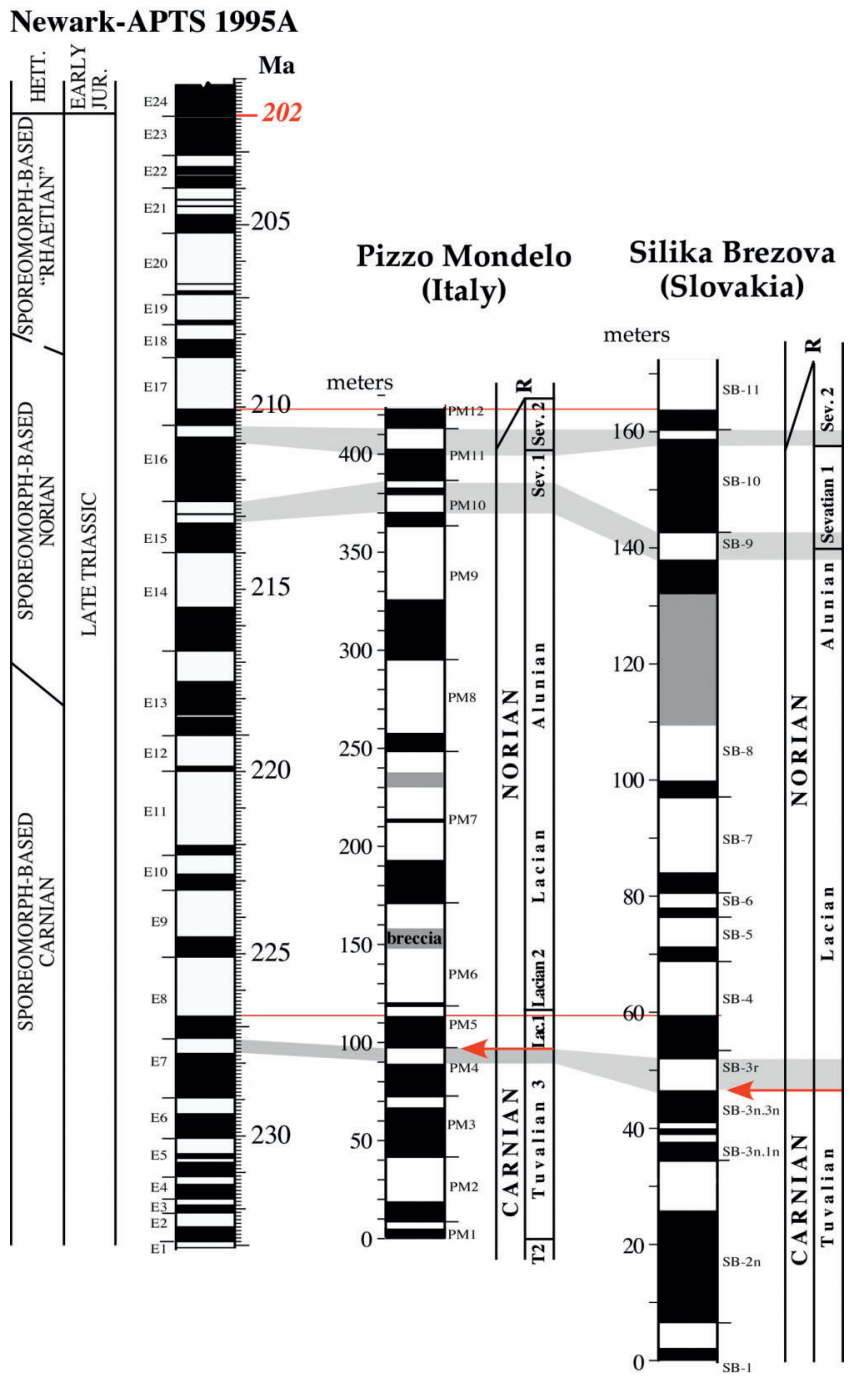

Figure 5 Correlation of the Newark-APTS 1995 with two key Late Triassic marine Tethyan sections. Correlation based on Muttoni et al. (2004) and Channell (2003).

respectively with the Newark-APTS. They concluded that the marine Carnian-Norian boundary fell much lower in the Newark basin section than previously recognised. Both Muttoni et al. (2004) and Channell et al. (2003) correlate the marine Carnian-Norian boundary to magnetozone E7r in Newark-APTS 1999A rather than E13 as suggested by previous interpretations of palynological and tetrapod data (Figs 4, 5). Both papers agreed in the apparent position of the Norian-Rhaetian boundary, which appeared in the same position in Newark-APTS 1999AB. This new correlation produced a change in the position of the Carnian-Norian boundary by 10 million years, making a Norian stage that lasted $20 \mathrm{Myr}$, suggesting that far-reaching revisions in global tetrapod biochronology were necessary. It is noted that this 'long Norian' concept has been incorporated into the recent Geological Society of America time scale of 2009 (Walker \& Geissman 2009) and, while it is gaining some acceptance, it remains controversial.

LeTourneau (2003) suggested a slight modification to the Newark-APTS based on the Campbell core from the Taylorsville basin (Fig. 6). Based on the best fit of the lithological correlation between the Newark and Taylorsville basins, magnetozone E7r should be expanded to agree proportionally with Taylorsville magnetozone T1n (Fig. 6). This introduces a small gap in the Newark basin section between the Cutaloosa and Prallsville members of the Stockton Formation

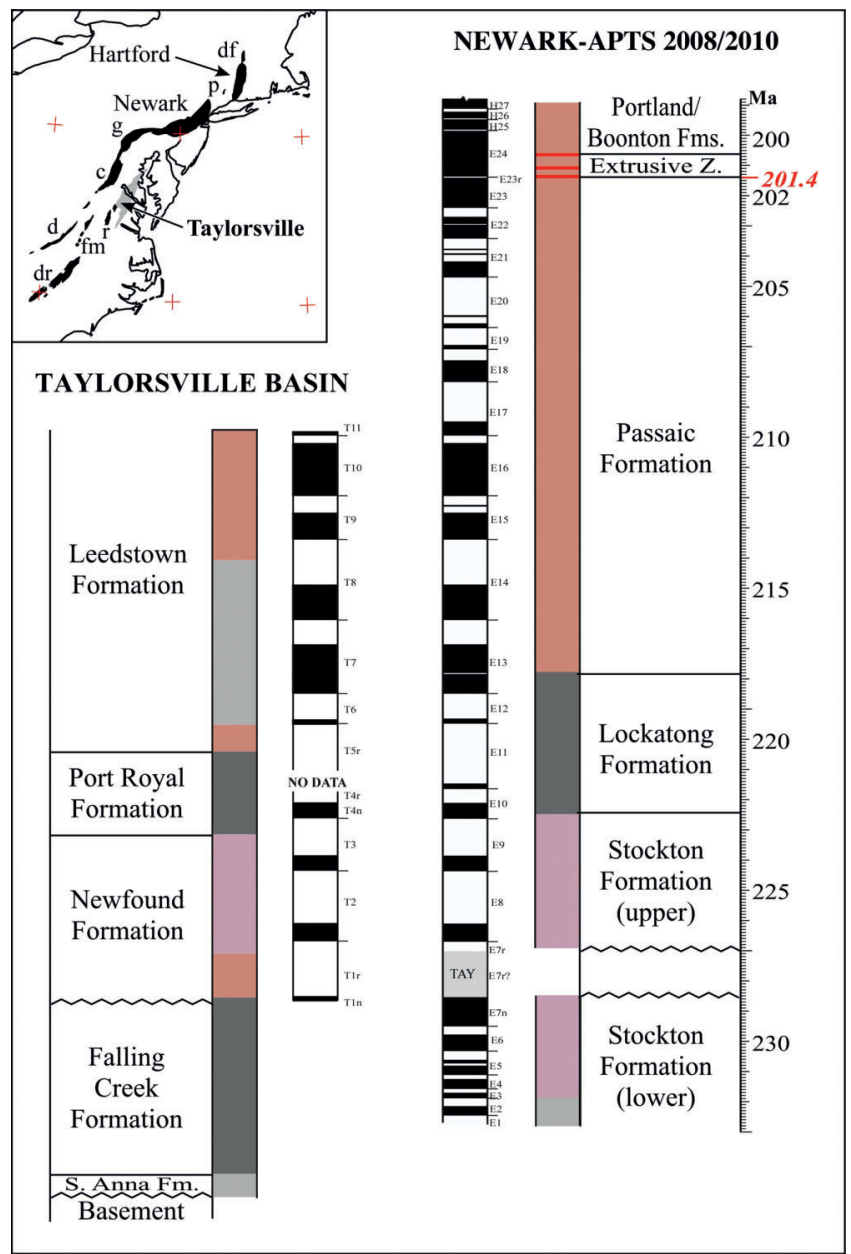

Figure 6 Palaeomagnetic correlation between composite section based on cores from the Taylorsville basin of Virginia, USA and the Newark-APTS 2010, showing the rational for extending the length of Newark basin chron E7r (TAY). Based on LeTourneau (2003) at the presumed hinge margin unconformity (sawtooth line) between tectonostratigraphic sequences II and III of Olsen (1997). Colours as in Figure 2.

that is in about the position to correlate with the tectonostratigraphic sequence boundary (TS II-TS III) seen in the Taylorsville, Fundy and Argana basins (Olsen 1997; Olsen et al. 2000; LeTourneau 2003; Schlische 2003). The timescale of Olsen \& Whiteside (2008) (Newark-APTS 2008) incorporates this small gap (Fig. 4d) as well as the magnetozones and cycles of the Portland Formation of the Hartford basin now fully described by Kent and Olsen (2008), as well as explicitly citing the $400 \mathrm{kyr}$ cycle as $405 \mathrm{kyr}$ (Laskar et al. 2004).

\section{Newark-APTS 2010}

New U-Pb dates from the lowest flow of the North Mountain Basalt of the Fundy basin of Nova Scotia (summarised and updated in Schoene et al. 2010) indicate a highly reproducable $\left({ }^{206} \mathrm{~Pb} /{ }^{238} \mathrm{~Pb}\right)$ age of $201 \cdot 38 \pm 0 \cdot 02$ (Schoene et al. 2010$)$, indistinguishable from the latest Rhaetian initiation of the endTriassic extinction (ETE). The North Mountain Basalt is equivalent, probably at the $20 \mathrm{kyr}$ scale, to the oldest flow of the Orange Mountain Basalt, based on basalt geochemistry (Olsen et al. 2003; Deenen et al. 2010), palaeomagnetic polarity stratigraphy of the immediately underlying strata (Deenen et al. 2011), cyclostratigraphy (Olsen et al. 2003; Whiteside et al. 2007) and palynology (Fowell \& Traverse 1995; Whiteside et al. 2007), and the new U-Pb date is consistent with the $\mathrm{U}-\mathrm{Pb}$ age of the Palisade sill that fed at least part of 
the Orange Mountain Basalt of the Newark basin (Olsen et al. 2003). Puffer et al. (2009) show, based on major and trace element data, that at least the early phase of the Palisade sill was comagmatic with the Orange Mountain Basalt, consistent with the stratigraphic and U-Pb dates. Therefore, the NewarkAPTS 2010 is tied to the $201.4 \mathrm{Ma}$ age of North Mountain Basalt, which is deemed equivalent to the Orange Mountain Basalt, within error (Fig. 4).

The recognition of the GSSP of the base Hettangian at Kuhjoch, Austria (Morton 2008a, b; Morton et al. 2008) requires comment. Although the end-Triassic terrestrial extinction level, or at least its base, remains below the Orange Mountain Basalt, the marker for the base of the Hettangian is the first appearance datum of the ammonite Psiloceras spelae that occurs above the base of the marine extinctions. Based on palynological and carbon isotopic correlation with the Newark basin section (Hounslow et al. 2004; Whiteside et al. 2007, 2010; Ruhl et al. 2010), the base Hettangian should correlate to the middle Feltville Formation at about $150 \mathrm{kyr}$ after the beginning of the end-Triassic extinction event; this placement is compatible with an ${ }^{206} \mathrm{~Pb} /{ }^{238} \mathrm{U}$ age of $201 \cdot 33 \pm 0 \cdot 13$ from an ash just above the first occurrence of $P$. spelae in New York Canyon, Nevada USA (Schoene et al. 2010). The position of the Rhaetian-Hettangian (Triassic-Jurassic) boundary is thus shown to be above that of both the base of the Classopollis meyeriana palynofloral zone and the base of the Orange Mountain Basalt (see Fig. 7). It is noted also that correlation of the Newark-APTS to the $\delta^{13} \mathrm{C}$ curves from the Newark and marine strata indicates that the CAMP event was synchronous with at least some of the extinctions within the end-Triassic extinction interval (Whiteside et al. 2010), bolstering a widely held view that CAMP provides a parsimonious explanation of the timing and duration of the event (e.g. Rampino \& Stothers 1988; Courtillot et al. 1996; McElwain et al. 1999; Hesselbo et al. 2002; Beerling \& Berner 2002; Marzoli et al. 1999, 2004).

The other major change from Newark-APTS 2008 to Newark-APTS 2010 is the inclusion of two options for the base of the Rhaetian: one based on the traditional base Rhaetian as it was understood by Cornet (in Olsen et al. 1996a) and correlated to the European section palynologically; and the other based on the inclusion of the Sevatian 2 into the Rhaetian and correlated by means of polarity magnetostratigraphy from the proposed Austrian GSSP (Krystyn et al. 2007a, b) by Hüsing et al. (2011) (see section 5, below).

It is noted that, in many ways, the application of marine stages and substages of Tethyan origin to non-marine sections often implies unsubstantiated temporal correlation of a marine biostratigraphy to non-marine sections. In this present paper, the substage terms Julian and Tuvalian (within the Carnian), Lancian and Alaunian (within the Norian) and Sevatian 1 and Sevatian 2 (Late Norian and Rhaetian) of Tethyan are used because they are the vocabulary for the abstractions of biostratigraphic concepts used in the critical papers that discuss the Tethyan 'standard stages' of the marine Late Triassic (e.g. Krystyn 2007a). It is recognised that because these substages (and stages!) are not formally referenced to specific sections and points (GSSPs), recognition of these substages (and stages), even in Tethyan marine sections, can hardly be better than the biostratigraphy on which they are based.

Relevant to discussions to follow, the Newark-APTS Carnian-Norian boundary at E7r has a nominal age of 227-229 Ma. However, this portion of the Newark basin section lacks cyclical lacustrine strata, and these ages represent an extrapolation. Radiometric constraints on the marine Carnian-Norian boundary (discussed below) suggest that the uncertainty in the stage boundary age is actually closer to
$6 \mathrm{Myr}$ (225-231 Ma) when comparing this boundary to other areas where magnetic polarity stratigraphy is lacking.

\subsection{Agreement between radioisotopic ages and Newark-APTS 2010}

The last few years have seen a revolution in the use of new $\mathrm{U}-\mathrm{Pb}$ techniques, producing high precision and apparently accurate dates that allow independent tests of the NewarkAPTS (Fig. 8). Table 1 has a list of the dates used. There are three published $\mathrm{U}-\mathrm{Pb}\left({ }^{206} \mathrm{~Pb} /{ }^{238} \mathrm{U}\right)$ dates from eastern North America, two of which can be precisely linked to the Newark cycle stratigraphy. The youngest is from basalt flows: $201.38 \pm 0.02 \mathrm{Ma}$, from gabbroid of the North Mountain Basalt of the Fundy basin (Schoene et al. 2010). The North Mountain basalt is the geochemical and cyclostratigraphic equivalent of the Orange Mountain Basalt of the Newark basin (see review in Olsen et al. 2003 and Whiteside et al. 2007), both lying close above the palynological transition between the Upper Balls Bluff-Upper Passaic and Classopollis meyeriana palynofloral zones. The other two dates have lower precision and are from sedimentary calcite (Table 1): $208 \cdot 5 \pm 2 \cdot 1 \mathrm{Ma}$, from stromatolite calcite from the lower Metlars Member of the Passaic Formation (Rasbury et al. 2003); and 211.9 $\pm 2 \cdot 1 \mathrm{Ma}$, from calcrete calcite from the lower middle New Haven Formation of the Hartford basin (Wang et al. 1998), whose correlation to the Newark basin section is constrained by a single palynoflorule (FOREST of Cornet 1977) at nearly the same level in the New Haven Formation. This palynoflorule is comparable to the Lower PassaicHeidlersburg palynofloral zone (Cornet 1977), but not correlatable at a finer level (Fig. 8).

Ash fall layers interbedded with marine units have provided a series of high-resolution dates within the last few years. Improvements from previous efforts come largely from single crystal dating and the chemical abrasion technique (CA-TIMS) (Pálfy \& Mundil 2006; Furin et al. 2006; Friedman et al. 2008; Schaltegger et al. 2008; Schoene et al. 2010). These dates are from marine sequences correlated largely by ammonite and radiolarian-based biostratigraphy to the European standard ages, including the apparent GSSP for the base of the Hettangian at Kuhjoch, Austria (Morton, 2008a, b; Morton et al. 2008). Correlation of the latest Triassic and Early Jurassic dates to the younger part of Newark-APTS 2008 is afforded via biostratigraphic and magnetostratigraphic correlation to the Montcornet core (Yang et al. 1996) from the Paris basin (Kent \& Olsen 2008); correlation of the Late Carnian age $\mathrm{U}-\mathrm{Pb}$ date (Furin et al. 2006) is by biostratigraphy to the marine magnetostratigraphies of Muttoni et al. (2004) and Channell et al. (2003) and thence to the Newark-APTS by magnetostratigraphy.

A U-Pb date of $225 \pm 3$ (Gehrels et al. 1987) from the Puppets Formation rhyolite interbedded with marine strata of the Alexander terrane in southern Alaska is between earliest Norian or Late Carnian and late Early Norian based on conodonts (Savage \& Gehrels 1987; Savage quoted in Gehrels et al. 1987) and cited as within the lower Norian Epigondolella quadrata Zone by Kozur \& Bachmann (2008). Furthermore, megafossil invertebrates constrain a thick $(\sim 300 \mathrm{~m})$ sequence below the dated rhyolite to 'earliest early Norian or latest Carnian' age (Berg 1973; Berg \& Cruz 1982). This is the only Norian marine $\mathrm{U}-\mathrm{Pb}$ date of which we are aware.

Correlation of the Newark-APTS 2010 McLaughlin cycles to the $\mathrm{U}-\mathrm{Pb}$ dates by least squares regression yields a line with a slope of $413 \pm 11 \mathrm{kyr} / \mathrm{cycle}$, validating the assumed period of $405 \mathrm{kyr}$ (Laskar et al. 2004) and a y-intercept of $201 \cdot 1 \pm$ $0 \cdot 3 \mathrm{Ma}$ corresponding to the age of the 0 th cycle (Fig. 8). The present authors view this as very strong independent support 


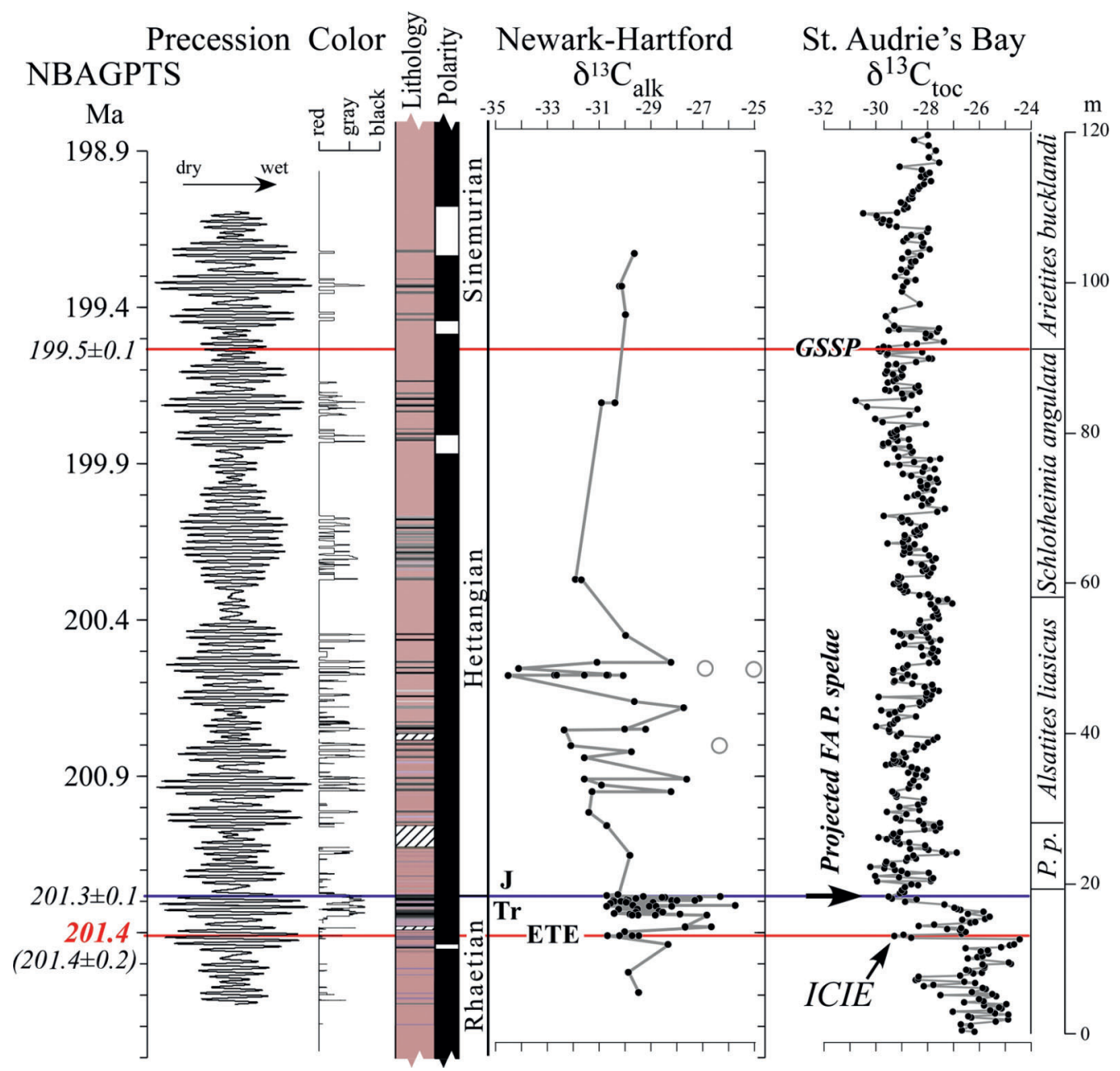

Figure 7 Compound-specific carbon isotopic records from Newark and Hartford basin strata interbedded with the CAMP lava flows (diagonal hachures) compared to marine total organic carbon $\left(\delta^{13} \mathrm{Ctoc}\right)$ records from St Audrie's Bay (and East Quantoxhead), UK (Ruhl et al. 2010). Compound-specific carbon isotopes are of the weighted mean odd $\mathrm{C}_{25}-\mathrm{C}_{31}$ n-alkanes $\left(\delta^{13} \mathrm{C}_{\text {alk }}\right)$. Newark and Hartford sections calibrated in time with Newark-Hartford orbitally tuned time scale (Newark-APTS 2010). Dates in italics are ${ }^{206} \mathrm{~Pb} /{ }^{238} \mathrm{U}$ single crystal CA-TIMS ages from the North Mountain Basalt of the Fundy basin (bold red), correlative with the Orange Mountain Basalt and Talcott Formation of the Newark and Hartford basins, and from marine ammonitebearing strata from Peru (black), correlated to the St Audrie's Bay isotope curve using the bio- and isotope-stratigraphy in Ruhl (2010) and Ruhl et al. (2010). The St Audrie's Bay section is shown in depth, with the fiducial levels of correlation (red lines) among the sections being the base of the ETE (extinction level), and the Hettangian-Sinemurian boundary constrained in the Newark and Hartford basins by palaeomagnetic stratigraphy (Kent \& Olsen 2008) (polarity) and cyclostratigraphy (from Ruhl et al. 2010). The blue line indicates the projected Triassic-Jurassic boundary (J/Tr), based on correlation to the first appearance datum (FAD) of the ammonite Psiloceras spelae, chosen as the marker for the base of the Hettangian at the GSSP in Kuhjoch, Austria (Hillebrandt et al. 2007) and projected to the Newark and Hartford data from St Audrie's Bay, itself correlated to Kuhjoch by Ruhl et al. (2009). Abbreviations: ETE=end Triassic extinction (initiation); GSSP=global stratotype section and point for the base of the Sinemurian at St Audrie's Bay (East Quantoxhead); ICIE = initial carbon isotopic excursion of reference $10 ; \mathrm{J} / \mathrm{Tr}=$ base of Triassic-Jurassic boundary; P. p.=Planorbis Zone. The open grey circles indicate points in the Hartford and Newark sections rejected because of thermal alteration or very low CPI values. (Adapted from Whiteside et al. 2010).

for the Newark-APTS, which agrees with all recent available independent quantitative information. Based on the NewarkAPTS, a series of conclusions can be drawn, with major implications for the tempo and mode of dinosaurian origin, diversification and rise to ecological dominance. Each of these is discussed below with a heading corresponding to a conclusion derived from the Newark-APTS.

\section{The end-Triassic faunal and floral break in the Newark-APTS is indistinguishable in age from the initial marine extinction}

As with other purported mass extinction events, much debate has focused on the possible synchrony between the marine and terrestrial extinctions at the close of the Triassic. The palynological data and interpretations of Cornet and colleagues (Cornet 1977, 1993; Cornet \& Traverse 1975; Cornet \& Olsen 1985) and tetrapod faunal data (Olsen et al. 1987, 2002a) supported a tight correlation between the two. However, a $\mathrm{U}-\mathrm{Pb}$ date of $199.6 \pm 0.3 \mathrm{Ma}$ from an ash bed in latest Rhaetian age strata of British Columbia (Pálfy et al. 2000) was (barely significantly) younger than the available ages ${ }^{40} \mathrm{Ar} /{ }^{39} \mathrm{Ar}$ and $\left.\mathrm{U}-\mathrm{Pb}\right)$ of the oldest CAMP lavas cited as about 200.6 Ma, suggesting that the continental extinctions led the marine extinctions (Pálfy et al. 2000). However, subsequent single crystal CA-TIMS dating of the same ash layer yielded a more precise and more accurate date of $201.7 \pm 0.6 \mathrm{Ma}$ (Friedman et al. 2008), nominally older but statistically 
Cycles vs. Ages

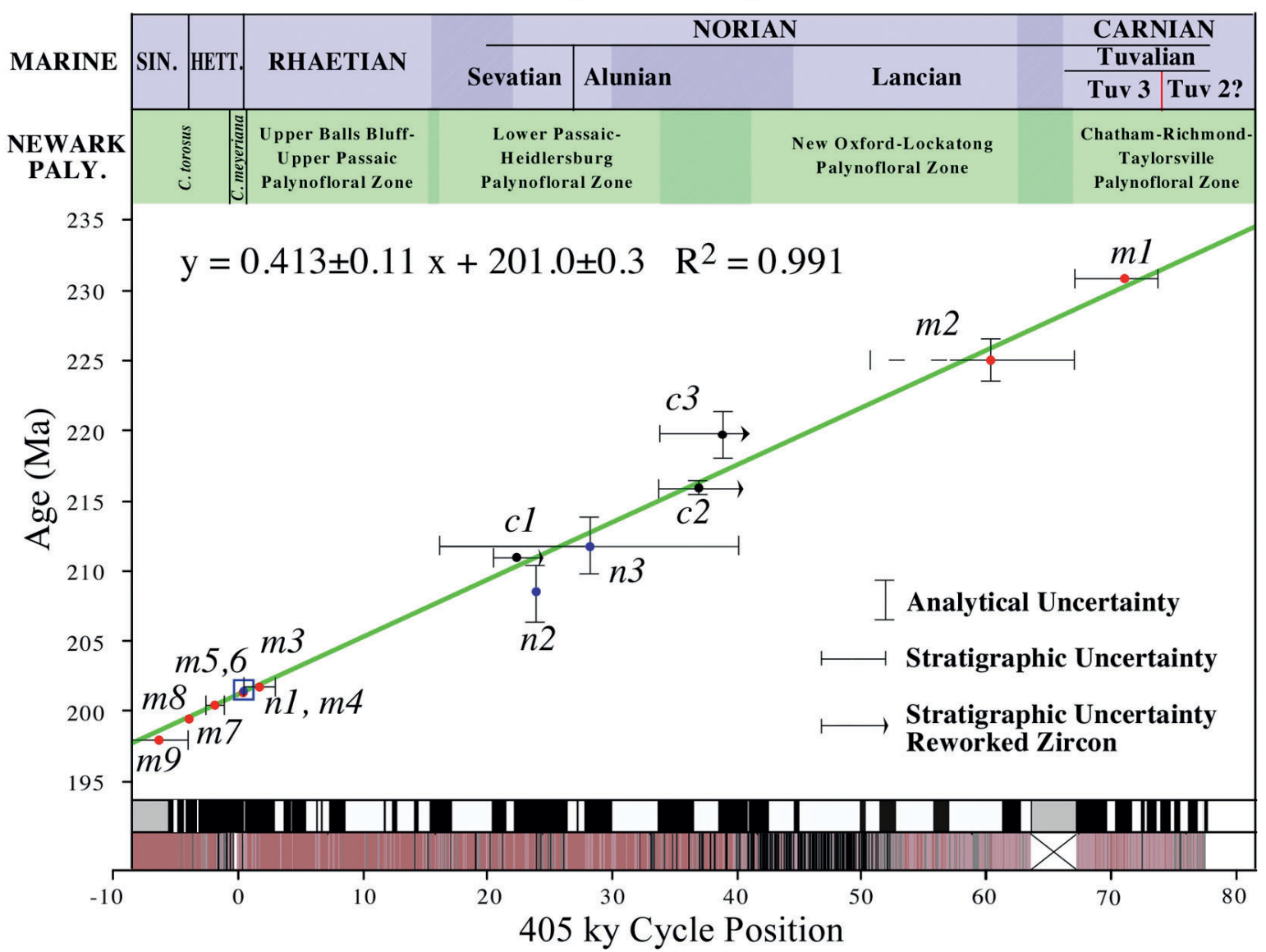

Figure 8 Correlation between number of putative 405 kyr cycles in the Newark and Hartford basin sections (from the Newark-APTS 2010) and ${ }^{206} \mathrm{~Pb} /{ }^{238} \mathrm{U}$ ages, with linear regression yielding a slope of $411 \pm 11 \mathrm{kyr} / \mathrm{cycle}$, indistinguishable from the hypothesised $405 \mathrm{kyr}$ duration of the cycle. Ages are from marine sections (red dots, $m$ labels), the Newark and Fundy basins (blue dots, $n$ labels) and the Chinle Formation (black dots, $c$ labels) (see Fig. 10). See Table 1 for list of ages used and their sources. The upper Bluewater Creek date of Irmis \& Mundil (2008) is here correlated to the upper Blue Mesa Member or basal Sonsela Member, based on Ramezani et al. (2010).

Table 1 U-Pb ages used to test age model for the Newark-APTS 2010.

\begin{tabular}{lccl}
\hline Labels* from Figures 8 and 9 & ${ }^{206} \mathrm{~Pb} /{ }^{238} \mathrm{U}$ age and error (Ma) & Depositional environment & Sources \\
$c 1$ & $211 \cdot 0 \pm 0 \cdot 7$ & Fluvial Chinle & Heckert et al. 2009 \\
$c 2$ & $216 \pm 1$ & Fluvial Chinle & Dickinson \& Gehrels 2009 \\
$c 3$ & $219 \cdot 2 \pm 0 \cdot 7$ & Fluvial Chinle & Mundil \& Irmis 2008 \\
$m 1$ & $230 \cdot 91 \pm 0 \cdot 33$ & Marine & Furin et al. 2006 \\
$m 2$ & $225 \pm 3$ & Marine & Gehrels et al. 1987 \\
$m 3$ & $201 \cdot 7 \pm 0 \cdot 6$ & Marine & Friedman et al. 2008 \\
$m 4$ & $201 \cdot 40 \pm 0 \cdot 18$ & Marine & Schoene et al. 2010 \\
$m 5$ & $201 \cdot 36 \pm 0 \cdot 13$ & Marine & Schoene et al. 2010 \\
$m 6$ & $201 \cdot 33 \pm 0 \cdot 13$ & Marine & Schoene et al. 2010 \\
$m 8$ & $200 \cdot 8+0 \cdot 6 /-0 \cdot 4$ & Marine & Friedman et al. 2008 \\
$m 9$ & $199 \cdot 53 \pm 0 \cdot 29$ & Marine & Schaltegger et al. 2008 \\
$n 1$ & $198 \cdot 0 \pm 0 \cdot 6$ & Marine & Palfy \& Mundil 2006 \\
$n 3$ & $201 \cdot 38 \pm 0 \cdot 02$ & Basalt flow & Schoene et al. 2010 \\
& $208 \cdot 5 \pm 2 \cdot 1$ & Stromatolite & Rasbury et al. 2003
\end{tabular}

indistinguishable from $\mathrm{U}-\mathrm{Pb}$ dates from the North Mountain Basalt and the age of the end-Triassic-extinction level in the Newark-APTS of 201.4, based on the age of the North Mountain Basalt (Schoene et al. 2010). These dates are in turn completely compatible with dates on ashes from marine strata elsewhere, bracketing the last appearance of Triassic-aspect ammonites such as Choristoceras and the first appearance of Jurassic-aspect ammonites including Psiloceras spelae (e.g. Schaltegger et al. 2008; Schoene et al. 2010).

Both the palynological transition and last appearances of Triassic-aspect non-crocodylomorph, suchian footprints such as Brachychirotherium and Apatopus appear abrupt in the 
Newark basin (data graphed in sections in Olsen et al. 2002a). Last appearances of Triassic-aspect ammonoids are also abrupt and synchronous, although recent detailed studies of the distribution of palynomorphs and other microfossils in European marine Triassic-Jurassic boundary sections (Hounslow et al. 2004; Hillebrandt et al. 2007; Kürschner et al. 2007; Hillebrandt \& Krystyn 2009) and continental sections in Greenland (McElwain et al. 2007) suggest a somewhat more protracted extinction sequence.

The fact that the Newark end-Triassic extinction was contemporaneous with marine extinctions at the $<100 \mathrm{kyr}$ level does not mean that all continental terrestrial extinction intervals are similarly correlated. In fact there are no other places in the world with as precise geochronological ties to the marine ETE as the Newark, a point that is discussed below in relation to Triassic ornithischians, for example. Because there is a clear magnetostratigraphic signature of the end-Triassic extinction level comprised of tiny chron E23r in a sea of normal polarity (E23n and E24n), at least in principle, other areas in which there is a continental faunal transition could be resolved at a similar level of precision.

\section{There is no substantive evidence of a gap just below the basalts in the Newark basin}

Van Veen (1995), Kozur \& Weems (2005, 2007, 2010), and Gallet et al. (2007) have argued for a significant gap in the Newark sections of several million years below the sporomorph assemblage typical of the igneous extrusive zone (i.e., CAMP interval) that omits minimally the middle and lower Rhaetian. This is a challenge to the usefulness of the Newark-APTS, especially for the Triassic-Jurassic transition, and challenges the apparent abruptness of the ETE and the ecological ascent of the dinosaurs. In fact, if there is such an unconformity, the entire continental ETE could be a protracted affair, spanning millions of years and could be completely disconnected from the marine extinction. At face value, the correlation between McLaughlin cycles and radioisotopic ages would exclude any major gaps (millions of years) in the Newark section, as do the magnetostratigraphic correlations of Hüsing et al. (2011) of the Newark and Alpine Rhaetian, in which the Newark is shown to have strata correlative to the middle and lower Rhaetian.

\subsection{Palynology and provincialism}

Sections in Exeter Township, Pennsylvania, have abundant palynologically productive levels (Fowell \& Olsen 1993), tetrapod fossils (e.g. footprints), a well-developed cyclostratigraphy and a palaeomagnetic polarity sequence (Olsen et al. 2002a, c) (Fig. 9), and have been the focus of discussions of a gap in the Newark sequence. Palynological assemblages from the Exeter area, at multiple sections spanning $\sim 1 \mathrm{~km}$ along strike, show a dramatic change $\sim 8-12 \mathrm{~m}$ below the Orange Mountain Basalt. Palynoflorules $(\mathrm{n}=10)$ within $80 \mathrm{~m}$ below this level are characterised by $5-60 \%$ vesicate, monosaccate pollen, including Patinasporites densus, Enzonalasporites spp. and Vallisporites ignacii (probably all from the same basic kind of conifer), 5-75\% Classopollis spp. (mostly Classopollis torossus), and Ovalipollis ovalis (Cornet 1977; Cornet \& Olsen 1985; Fowell \& Olsen 1993; Fowell et al. 1994). These assemblages can be very diverse, with abundant bisaccates, monosulcates, and spores, many of which are unknown outside of the Triassic. There is no doubt that these assemblages are of Triassic age and closely resemble assemblages from kilometres lower in the Newark basin section.

These typical Late Triassic assemblages are succeeded by a thin interval with $15-89 \%$ spores that was first discovered by

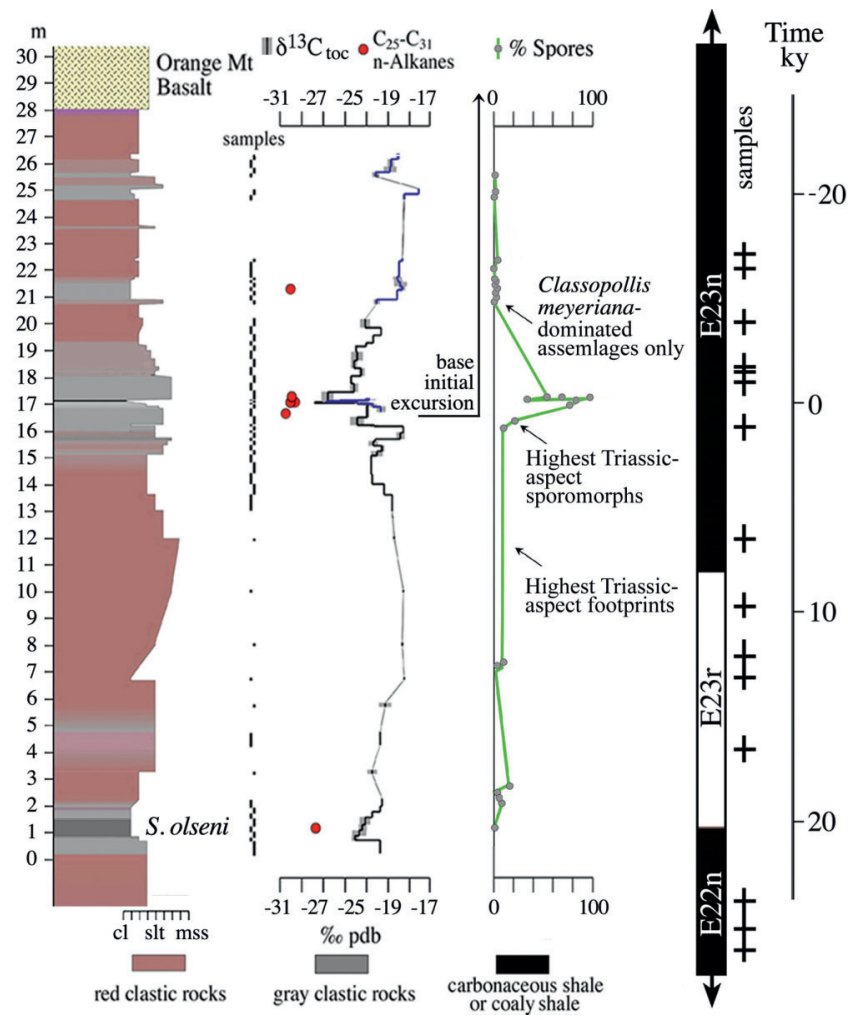

Figure 9 Section of uppermost Passaic Formation, Exeter Township, Pennsylvania, USA showing (from left to right) the litho-, chemo-, bioand magnetostratigraphy and the position of the conchostracan Shipingia olseni. Magnetostratigraphy from Olsen et al. (2002a).

Litwin (cited in Smith et al. 1988) and described by Fowell and colleagues (Fowell \& Olsen 1993; Fowell 1994; Fowell et al. 1994; Olsen et al. 2002a, c). The trilete spores Anapiculatisporites, Converrucosisporites deltoidospora, Dictyophyllidites, Granulatisporites, Kyrtomisporis, Porcellispora, Reticulatisporites, Todisporites and Verrucosisporites are present, along with Classopollis spp. This assemblage lacks any taxa unique to the Triassic and, because of the abundance of fern spores, has been called a fern spike (Olsen et al. 2002a, c). The last occurrence of taxa unique to the Triassic is an assemblage about $75 \mathrm{~cm}$ below this fern spike (sample 6-2 of Fowell 1994) dominated by Classopollis (73\%) but with $\sim 10 \%$ Patinasporites (Olsen et al. 2002c).

Until recently, there was only one palynoflorule from the Exeter area above the fern spike, JB4 of Cornet (1977) (Olsen et al. 2002a, c). This assemblage is dominated by Classopollis meyeriana (99\%: Cornet 1977), with some spores. However, 12 additional levels were found to be productive at a temporary excavation (Fig. 9) and all are very strongly dominated (>95\%) by Classopollis meyeriana. Rare bisaccates, monosulcates and spores are present, but the vesicate, monosaccate pollen, including Patinasporites densus and in fact all Triassic-aspect sporomorphs, are absent. These assemblages closely resemble those of the overlying Feltville and Towaco formation assemblages (e.g. Cornet 1977). This transition, occurring through an interval less than $1 \mathrm{~m}$ thick, is the most dramatic in the entire Newark basin sequence and in fact in all of eastern North America.

Cornet (1977) noted, as have other authors since, that the Triassic-aspect assemblages below the fern spike lack taxa typical of the Rhaetian of Europe and Greenland. In particular, Triancoraesporites spp., Cornutisporites seebergensie, Rhaetipollis germanicus, Heliosporites reissingeri, Ricciisporites tuberculatus, Zebrasporites spp. and Acanthotriletes varius (Cornet 1977) have not been found in eastern North America. 
Van Veen (1995) points out that in Europe, vesicate pollen virtually disappear at the base of the Rhaetian. Hence, because he did not dispute the Jurassic age of the assemblages above the fern spike, Van Veen (1995) argued that the Newark basin section is condensed near the Triassic-Jurassic boundary and the sedimentary cycles present are not of Milankovitch origin (as in Gradstein et al. 1994, p. 24,056), with the implication that the entire Rhaetian is missing or extremely condensed. Kürschner et al. (2007), Lucas \& Tanner (2007) and Cirilli et al. (2009) agreed with this hypothesis. However, Cornet (1997), Cornet \& Olsen (1985) and Fowell \& Olsen (1993) argue that this lack of European Rhaetian taxa is due to geographic provincialism, not an age difference. The idea that the vesicate monosulcate taxa Patinasporites, Enzonalasporites and Vallisporites might be geographically provincial is not completely unconventional. For example, although such taxa are common in parts of the Tethyan realm (Buratti \& Cirilli 2007) they are much less common or absent from localities in the boreal realm regardless of age (Hochuli et al. 1989; Mørk et al. 1992; Hochuli \& Vigran 2010). Likewise, they are rare or absent from the southern hemisphere high-latitude Ipswich assemblage (Dolby \& Balme 1976; Traverse 2007). Cirrilli et al. (2009) argue that because of the wide geographic distribution of the Patinasporites and vesicate cohorts, climatic provinciality cannot be the cause of the absence of these forms from the Rhaetian of alpine and central Europe. However, in the Late Triassic that region was on the border between the arid belt and temperate realms and translated $20^{\circ}$ northward through at least the Norian and Rhaetian (Kent \& Tauxe 2005). There is a corresponding time-transgressive shift in facies in continental strata, reflected in vertical successions from red beds and evaporates to grey strata, sometimes with coals in the northern sections. Similarly, classic Rhaetian taxa of Europe, such as Rhaetipollis germanicus and Zebrasporites spp., extend into the Early Carnian near the Late Triassic North Pole in northern Middle Siberia (Kozur \& Weems 2007; Ilyina \& Egorov 2008). Thus, it is no surprise that the tropics contained floras that differed from the temperate region, or that a flora might be time-transgressive as central Pangea translated northward.

It follows that because at any given time the region in which Patinasporites et al. were common was latitudinally and presumably climatically limited, and central Pangea drifted northward through the latter Triassic, the absence of classic European taxa such as Rhaetipollis in the latest Triassic of the tropics is to be expected. Consequently, while the sporomorph taxa may be extremely useful in demarcating a floral event, they may be of limited use in correlation between biotic provinces or across climate belts. Forcing correlation by introduction of hiatuses that lack independent methods of testing, biostratigraphic or otherwise, eliminates biologically informative patterns that are potentially much more informative than the correlations themselves. Thus, the present authors do not regard the lack of 'standard Rhaetian' sporomorph taxa, or the presence of vesicate monosaccate pollen as significant evidence of a hiatus in the Exeter section, or elsewhere in the Newark basin, or elsewhere in eastern North America or Morocco below the oldest basalt.

\subsection{Conchostracan biostratigraphy}

Another line of evidence cited as indicating a major hiatus near the palynological ETE in the Newark Supergroup in general is conchostracan biostratigraphy, championed by Kozur \& Weems $(2005,2007,2010)$. Based on their interpenetration of the biostratigraphy of early Mesozoic representatives of this ubiquitous yet remarkably sparsely studied group, Kozur \& Weems assert the presence of a $5 \mathrm{Myr}$ hiatus below the palynological ETE in the Newark basin and elsewhere in Eastern North America. The best-documented area is in the Newark basin, again in the Exeter section (Fig. 9).

A well-developed dark grey lacustrine bed is present $\sim 16 \mathrm{~m}$ below the fern spike and the highest occurrence of Triassicaspect palynomorphs in the Exeter area marking the base of the Exeter Township Member (Olsen et al. 1996a) (Fig. 9). In addition to abundant Patinasporites and other sporomorphs, the unit also produces conchostracans (clam shrimp) that have been used for biostratigraphy. Kozur \& Weems (2005, 2007, 2010) have documented the occurrence of the conchostracan form Shipingia olseni from this unit. According to them, this taxon indicates a Late Norian (middle Sevatian) to Early Rhaetian (Late Sevatian) age. They further identify conchostracans above the lowest basalt (Midland Basalt) of the Culpeper basin as Euestheria brodieana. The latter conchostracan occurs in the Cotham Member of the Lilstock Formation in England (Mayall 1983) that is Late Rhaetian, based on the definition of the base Jurassic by ammonites (Psiloceras planorbis as a proxy for $P$. spelae), which lies in superposition. It also occurs in lower Rhaetian strata (late Sevatian) in Germany (cited by Kozur \& Weems 2005 without mention of locality or reference). In Great Britain it appears to occur at the top of the contorted interval interpreted as a seismite (Mayall 1983; Simms 2007), corresponding to the base of the 'initial' isotopic excursion of Hesselbo et al. (2002) and within the 'dead zone' that marks the marine extinction level (Mander et al. 2008). The present authors have been able to ascertain that a form indistinguishable from the Midland form (Euestheria brodieana) occurs in the lower Shuttle Meadow Formation (Hartford basin), homotaxial and time equivalent of the Midland Formation (N. G. McDonald collection, Museum of the Earth, Ithaca, NY). Kozur \& Weems (2007, fig. 10), agreeing in kind but not in detail with Van Veen's (2005) interpretation, argue that there is a 'significant unconformity' spanning the entire early Rhaetian (late Sevatian plus early traditional Rhaetian: Fig. 9) in the Newark basin, and in the Newark Supergroup in general, below the oldest basalt and above the E. olseni zone, and specifically between the grey shale marking the base of the Exeter Township Member of the Passaic Formation and the Orange Mountain Basalt, as discussed above.

Kozur \& Weems $(2005,2007)$ argue that conchostracans they call Bulbilimnadia sheni that occur with Euestheria brodieana in the Midland Formation (and succeeding Hickory Grove Basalt, Turkey Run Formation and Sander Basalt in the Waterfall Formation) indicate a Hettangian age, because they are found with the conchostracans Palaeolimnadia cf. longmenshanensis and P. cf. semicircularis. However, Bulbilimnadia sheni is unknown from strata directly dated by marine invertebrates, whereas Palaeolimnadia longmenshanensis and $P$. semicircularis are only known from China (Chang et al. 1976), from continental strata correlated to the marine stages by means of floral remains. Kozur \& Weems $(2007,2010)$ also cite Bulbilimnadia sheni from the middle East Berlin Formation of the Hartford basin (Westfield Fish Bed), and the present authors have found this taxon in the exact homotaxial and time equivalent in the Newark basin, 'cycle P3' of McCune (1990) (Olsen 2010).

Kozur \& Weems $(2005,2007)$ identified another conchostracan assemblage from the upper Waterfall Formation of the Culpeper basin. This assemblage is dominated by Bulbilimnadia froelichi, with scarce Palaeolimnadia baitianbaensis known from China (Kozur \& Weems 2005), and is asserted to belong in the later part of the early Hettangian.

On the basis of these conchostracans, Kozur \& Weems (2007) conclude that the Triassic-Jurassic boundary (base 
Hettangian) lies near the middle of the CAMP zone, which is about the position of the Preakness Basalt in the Newark basin, not at the fern spike, below the Orange Mountain Basalt. The present authors do not necessarily disagree with this correlation of Kozur \& Weems of the base Hettangian in general, except to note that what is hypothesised to be Late Rhaetian is based on the presence of Euestheria brodieana that Kozur \& Weems agree extends into the Hettangian, and based on the apparent absence of the Hettangian forms. However, the latter are either, thus far, endemic to eastern North America or from strata that are not directly tied to a marine fauna themselves. There are no conchostracans from the Early Hettangian of England or the Germanic basin, because those sections are marine. Thus, while their placement of the base Hettangian may be correct, the taxa used for correlation have no direct ties to the marine stage boundaries, let along the first appearance datum of Psiloceras spelae. The position of the first appearance datum of Psiloceras spelae is projected by Whiteside et al. (2010) to be below that suggested by Kozur \& Weems (2007), but still between their highest purported Rhaetian and their lowest purported Hettangian conchostracans, in the lower Feltville and Lower Shuttle Meadow formations (Fig. 7).

The GSSP definition for the base Hettangian is the level marking the FAD of $P$. spelae at Kuhjoch, Austria, a boundary definition detached from what must now be termed the end-Triassic extinction (ETE), and becomes a datum of little apparent relevance to any specific process. Hence its correlative position in eastern North America does not appear to bear on any specific process-oriented problem. After all is said and done, the placement of the Triassic-Jurassic boundary within the basalt flow sequence has no apparent bearing on the relationship of the extinction event to the CAMP. This is a point that is seemingly lost in quite a few recent papers (e.g. Lucas \& Tanner 2007; Kozur \& Weems 2008; Cirrilli et al. 2009). However, the hypothesised gap below the basalts remains pertinent to the nature of the extinction and to the time scale, and hence to the rise of dinosaur ecological dominance.

Support for the gap hypothesised below the oldest basalt in eastern North America of Kozur \& Weems (2005, 2007, 2010) comes down basically to the apparent juxtaposition of strata with Euestheria brodieana above and Shipingia olseni below, without intervening strata containing Anyuanestheria? n. spp. without $S$. olseni. The latter are known from the Exter Formation of Germany and Polish strata proposed to be correlative to the lower Rhaetian. However, it is pointed out that the strata containing all of these lack the guide fossils (ammonites and conodonts) of the Alpine sections on which the yet to be formally defined Rhaetian is based, and thus their relative age is tenuous as well. The recognition of this gap depends on the one hand with substage-level correlation between the mostly continental lower Rhaetian facies of Germany and Poland with the fully marine Alpine facies of the sub-stages of the Rhaetian and, on the other hand, with near perfect fidelity of faunas separated by thousands of kilometres and across climate zones. The present authors doubt either of these requirements is met. This seems to be a repeat of the same problem that plagues the palynology of this interval, but at a smaller temporal scale. Indeed, present-day conchostracan species, genera, and even some families, are known to be endemic at varying scales, despite their reproductive strategies that would seem to encourage wide distributions. For example, in a recent review of freshwater branchiopod diversity, Brendonck et al. (2008, pp. 172-173) state, "Some clam shrimp genera like Cyzicus and Eocyzicus appear to be Laurasian, with their current ranges encompassing Eurasia, Africa and North America. The genus Lepthesteriella, in contrast, seems
Gondwanan, and occurs in Africa, Madagascar and Asia. Lynceids are cosmopolitan, save in Antarctica. Cyclestheria hislopi (if representing only one species, which is uncertain) is pantropical". Individual genera and species of conchostracans tend to exhibit greater endemism (e.g. Naganawa \& Zagaswith 2002; Tims 2009). It is not obvious why early Mesozoic forms would be expected to behave profoundly differently, and be less subject to biotic provincially, than those of today.

The absence of a taxon of a poorly known group in a poorly studied region is insufficient grounds for inserting a hiatus in a section for which there is no physical evidence for one (see below). Indeed, the correspondence between ages assessed using conchostracan biostratigraphy and independent radioisotopic ages is poor (see below). Therefore, the present authors are not compelled by the conchostracan biostratigraphy suggesting a significant hiatus below the oldest basalts, and argue instead that there remains an important biostratigraphic signal. A hypothesis consistent with conchostracan distribution and independent radioisotopic ages prior to the onset of the end-Triassic extinction, is that Triassic conchostracans exhibited considerable provinciality, while after the ETE they were more cosmopolitan, perhaps including widespread 'disaster taxa' (cf. Roland \& Bottjer 2001).

\subsection{Palaeomagnetic polarity stratigraphy}

Gallet et al. (2007) argue that the Rhaetian is at least partly missing in the Newark basin, based on palaeomagnetic polarity stratigraphy from highly condensed marine Alpine facies carbonates in Turkey. However, their stratigraphic arguments rest almost completely on the acceptance of the hypothesised gap below the basalts of Kozur \& Weems (2005). While Gallet et al. (2007) assert that, ". . . the top-Triassic magnetostratigraphy now appears well established from several data sets ...", exclusive of the Newark, in fact none of the marine sections of the Alpine facies of the late Norian and Rhaetian examined by Gallet et al. (2007) and Krystyn et al. $(2007 a, b)$ extend to the base of the Jurassic on the basis of palaeontological criteria, or deep into the Norian without intervening faults of unknown throw (Fig. 10). In fact, these marine sections are so short that attempts at correlating them to each other using biostratigraphy require so much distortion that the composite 'Tethyan Sevatian-Rhaetian' ends up being virtually arbitrary, because the most fundamental time proxies in stratigraphy are essentially lost: superposition for the arrow of time and thickness as a proxy of its duration.

Instead, it is argued that many Tethyan sections are riddled with significant lacunae that result in the different patterns of polarity stratigraphies of the sections. Multiple hypothesised gaps (11 in four sections) are required to reconcile the polarity sequences of biostratigraphically correlated Carnian-Norian sequences in adjacent nappes for the parts of the Tethyan sections examined by Gallet et al. (2000), once the idea that the two nappes came from different hemispheres (Gallet et al. 1992, 1993) was abandoned. The presence of significant gaps in the Rhaetian Tethyan sections is also suggested by the simple observation that there are significantly more polarity zones in the Newark basin sequence than in any of the Tethyan sections that are thought to correlate in a broad way (e.g. Fig. 10). It is concluded that hiatuses and attendant missing or truncated polarity zones most probably occur in the Tethyan sections, and there is no evidence based on the magnetostratigraphic data alone that demands there be a hiatus in the Newark. Indeed, the high-resolution sampling of the proposed baseRhaetian GSSP of Hüsing et al. (2011) demonstrate a particularly good match with the Newark, showing that the supposed gap in the Newark does not exist. 


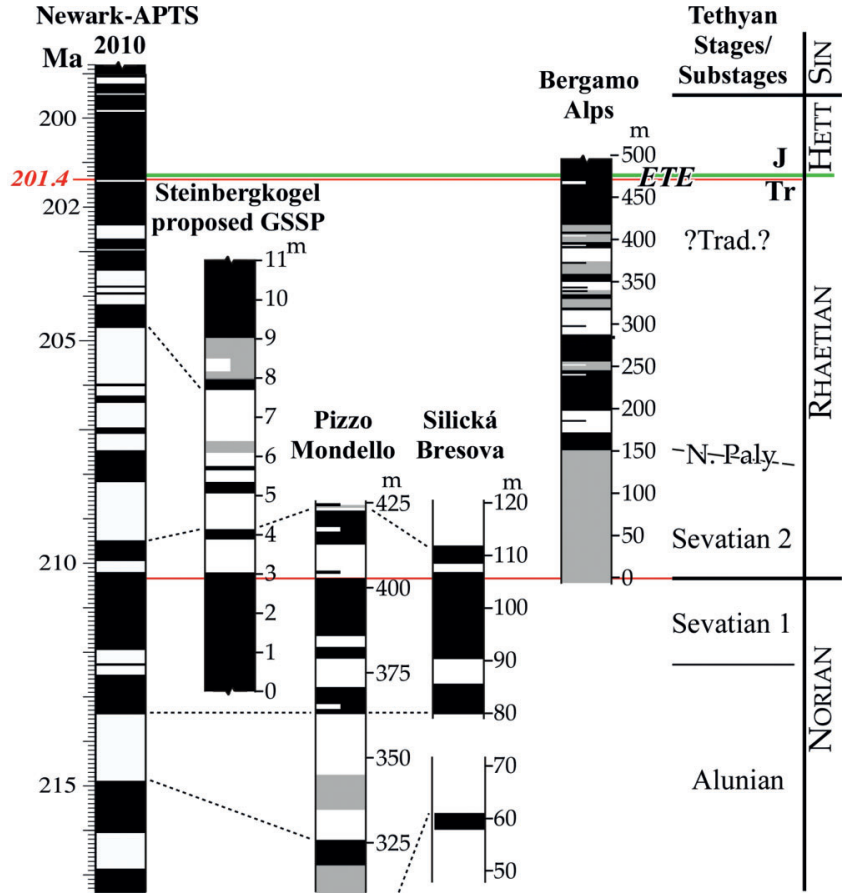

Figure 10 Comparison of Alpine and Sicilian Rhaetian sections with the younger part of the Newark-APTS 2010, with correlation based on original authors and Hüsing et al. 2011. Principal magnetostratigraphically-independent fiducials are ETE (end-Triassic extinction initiation) and Alunian-Sevatian boundary (for the marine sections). Steinbergkogel section from Hüsing et al. 2011; Pizzo Mondello section from Muttoni et al. 2004; Silická Brezová section from Channell et al. 2003; Italcementi Quarry and Brumano sections merged into Bergamo Alps section (retaining uninterpretable intervals from both sections), from Muttoni et al. 2010. Black indicates normal polarity; white reverse polarity; grey uninterpretable or ambiguous polarity; and half bars indicate single samples of interepretable polarity. 'N. Paly' indicates position of the palynological transition regarded by Cornet (1977) and Cornet \& Olsen (1985) as indicating the Norian-Rhaetian boundary. '?Trad?' indicates the highly uncertain relative position of the 'traditional' Norian-Rhaetian boundary of Mojsisovics $(1869,1893)$.

Identification of the very short chron E23r at multiple localities, both within and outside the Newark basin, also argues for no gap in the upper Passaic Formation. Originally, E23r was identified in the Martinsville core near the top of the Passaic Formation (Fig. 11) and in outcrops at Grist Mills in Exeter Township about $113 \mathrm{~km}$ away, and then about $1 \mathrm{~km}$ east of the Grist Mills section. At both latter locations the base of E23r is in contact with the conchostracan-bearing shale containing Shipingia olseni and underlies more Patinasporites densus-bearing shales (Lucas et al. 2011). Recently, Deenen at al. (2010) identified E23r below the Argana basalt, again surrounded by pollen and spore assemblages with vesicate pollen, in this case Enzonalasporites vigens; Whiteside et al. (2007) report the related Patinasporites densus from the same strata. Deenen et al. (2011) also identified E23r from the Fundy basin at Partridge Island, near Parrsboro, Nova Scotia, again within strata containing vesicate pollen. In all cases, E23r bears a consistent relationship with the overlying sporomorph extinction level as well as underlying strata with Shipingia olseni, consistent with the differences in accumulation rate between the basins. The initial palynological extinction horizon is then overlain by the oldest basalt in each basin, except in Morocco where the basalt is in direct contact with vessicate pollen-bearing strata plausibly at the extinction level (Marzoli et al. 2004; Deneen et al. 2010). It is thus extremely hard to envision a significant erosional or non-depositional hiatus in these rift sequences between either the youngest
Shipingia-bearing beds or the youngest vesicate pollen-bearing bed and the extinction level and overlying basalt in multiple basins on two continents. Instead, these observations are far more consistent with more or less continuous deposition.

\subsection{Cyclostratigraphy}

The cyclostratigraphy of the Newark basin sequence has long been used to estimate the duration of the CAMP event in the basin (Olsen et al. 1996b, 2003; Whiteside et al. 2007). Independent, strong corroboration of these estimates and the underlying Milankovitch origin of the cycles themselves have been recently obtained from high-precision $\mathrm{U}-\mathrm{Pb}$ ages from the basalts themselves (Blackburn et al. 2009). This cyclostratigraphy also provides evidence against the presence of a major unconformity (Olsen et al. 2003; Whiteside et al. 2007).

Passaic Formation strata starting a few tens of metres below the Orange Mountain Basalt exhibit an upward increase in the amplitude of cyclical climate sensitive sedimentary facies fluctuations, compared to underlying strata. The increase in grey and black shales in these cycles is consistent with being deposited during an interval of high precession variance in a $\sim 100$ kyr eccentricity cycle. Strata of the overlying lower Feltville Formation have cyclical facies changes indicating even higher precessional variability consistent with the next $100 \mathrm{kyr}$ cycle. Together, they are most parsimoniously interpreted as two successive 100-kyr cycles in the portion of a 405-kyr cycle characterised by peak precessional variability (Olsen et al. 2003; Whiteside et al. 2007). With this interpretation, any hiatus present would have to be a rather precise multiple of $400 \mathrm{kyr}$, which is not a simple interpretation.

\section{The Rhaetian is relatively long (+6 Myr)}

Traditionally, the duration of the Rhaetian has been considered short, especially compared to the Norian or Carnian stages. This is largely because it was generally thought of as thin with few biozones - in fact originally only one. That was the Avicula contorta zone of Mojsisovics (1893), now known to be restricted to a specific facies and a poor guide fossil. The Rhaetian was dropped as a recognised stage for a decade in North America because of this (Tozer 1979) and then reinstated by bureaucratic fiat (IGCP-Subcommission on Triassic Stratigraphy: Visscher 1992). The base of the Rhaetian remains formally undefined, but there are proposals resulting in a somewhat expanded Rhaetian including the so-called Sevatian 2, not formally defined but usually grouped with the Norian (also not formally defined) (e.g. Krystyn et al. 2007a, b) (Fig. 12), with two ammonite zones and three or more conodont zones. Apart from these definitional issues enlarging the scope of the Rhaetian, and the thinness of the stage at a number of sections, there are no geochronological constraints on the duration of the Rhaetian, other than the Newark-APTS.

The problem of the duration of the Rhaetian and correlation to the Newark-APTS is intimately related to the problem of the supposed gap in the upper Passaic Formation, discussed above. Correlation of upper Passaic strata of the Newark basin with the Rhaetian had been based purely on palynology in the Newark basin. Cornet recognised the Norian-Rhaetian transition (i.e. the base of the Balls Bluff-Upper Passaic palynofloral zone) by the appearance of Classopollis torosus and Granuloperculatipollis rudis and an increase in Classopollis spp. abundance, especially Classopollis meyeriana that is abundant to dominant in most samples (Cornet 1977; Cornet \& Olsen 1985). As already discussed, many typical European Rhaetian sporomorph taxa are absent in the Newark basin and Patinasporites and related vesicate taxa are common, evidently because of 


\section{Jacksonwald \\ Syncline Newark Basin, USA}

meters

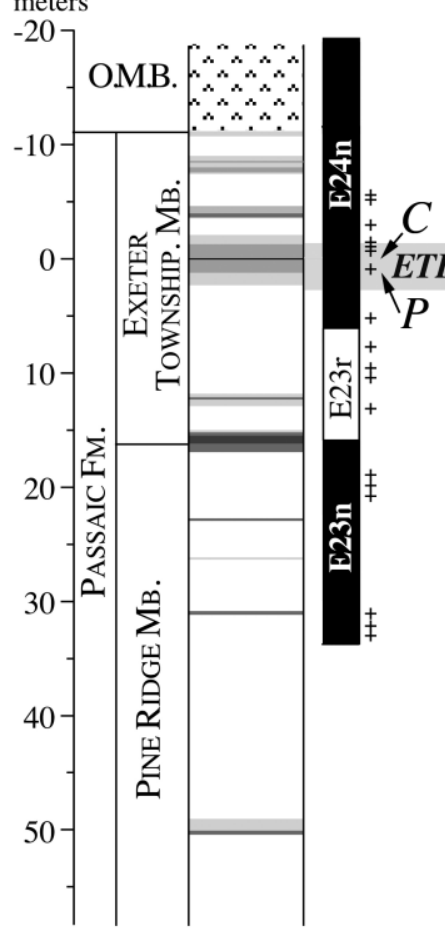

Martinsville no. 1

Newark Basin, USA

core

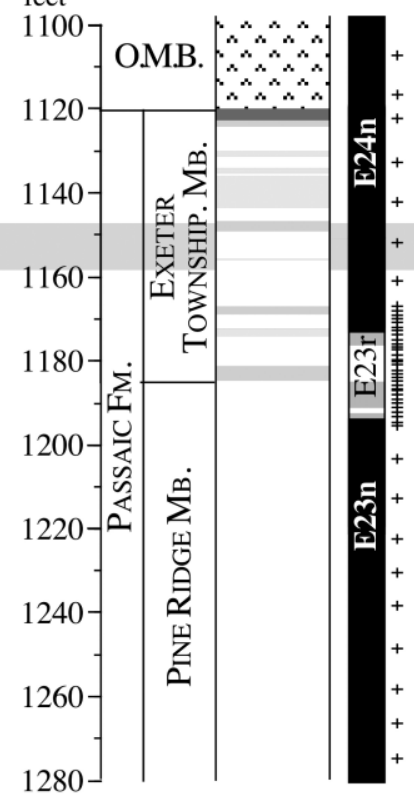

Fundy

Basin, Canada
Argana

Basin, Morocco

meters
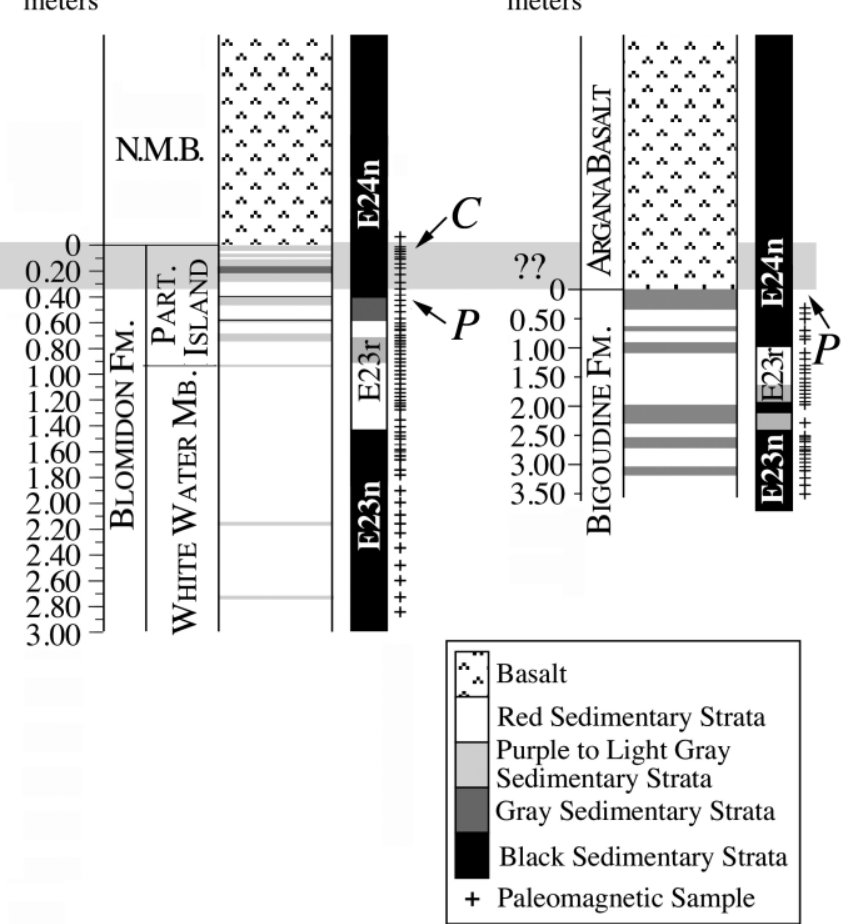

Figure 11 Sections in which magnetochron E23r has been observed. These sections are correlated to each other on the basis of two levels: first, by the ETE, marked by the last appearance of vesicate pollen (including Patinasporites densus); and second, by the midpoint of E23r itself. The Jacksonwald syncline and Martinsville no. 1 sections from the Newark basin are modified from Kent \& Olsen 1999 and Olsen et al. 2002a. The Argana basin and Fundy basin sections are modified from Deenen et al. 2010 and 2011, respectively. $\boldsymbol{P}$ is the highest occurrence of vesicate pollen and $\boldsymbol{C}$ lowest occurrence of a sporomorph assemblage lacking vesicate pollen, based on Olsen et al. 2002a, Fowell \& Traverse 1995, Marzoli et al. 2004, Whiteside et al. 2007 and Cirilli et al. 2009. Note the consistent relationship between the ETE and E23r, which is not what would be expected if the ETE itself marks an unconformity representing millions of years.

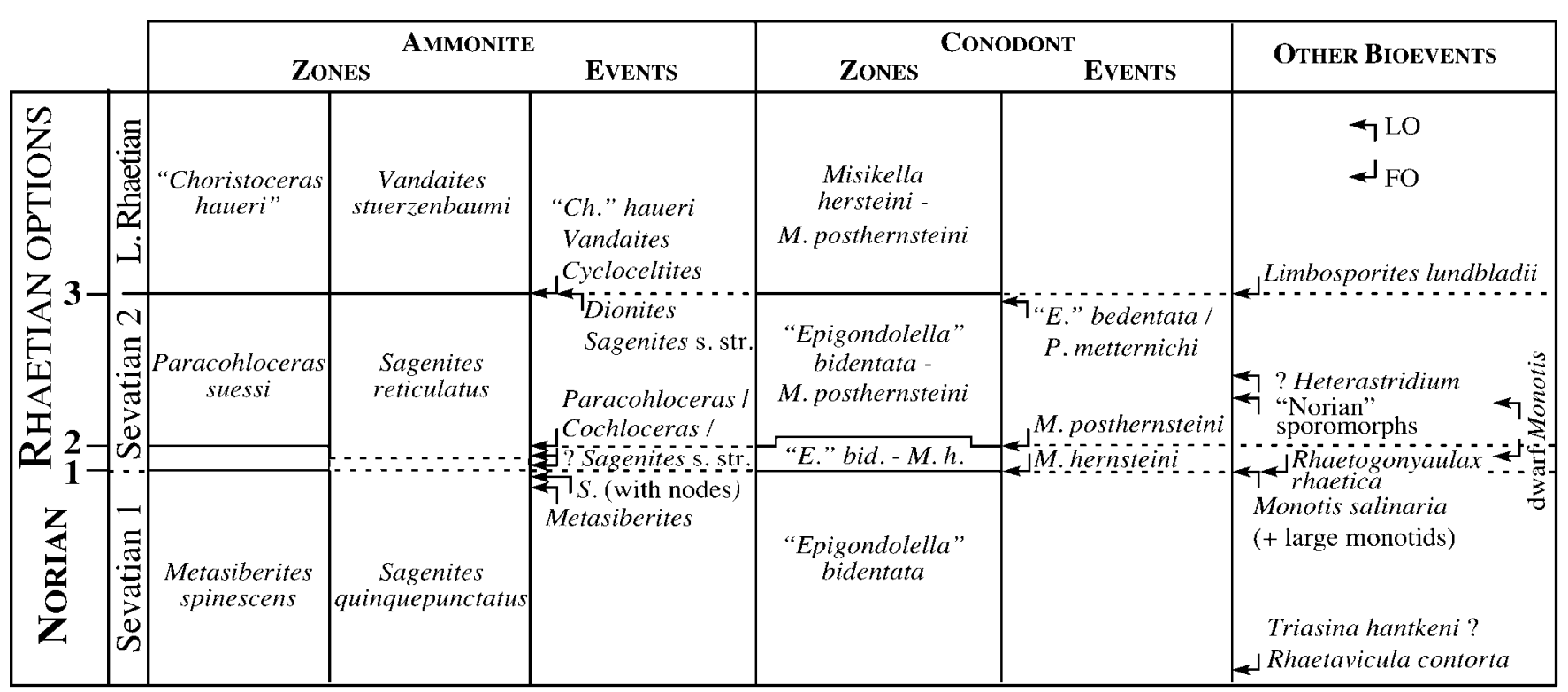

Figure 12 Recent revisions of the definition of Rhaetian according to Krystyn et al. (2007a) showing the correlation of ammonoid and conodont zones based on data from the proposed GSSP at Steinbergkogel, with integration of additional bioevents from elsewhere. Option 3 at the top of the Sevatian 2 is the base of the 'traditional' Rhaetian, but is not represented in the exposed section at the proposed GSSP section in Steinbergkogel; options 2 and 3 (favoured by Krystyn et al. (2007a, b) would place a portion of the 'traditional' upper Norian (Sevatian 2) in the Rhaetian.

provinciality (Kozur \& Weems 2007). However, the correlation between the Tethyan Norian-Rhaetian boundary and NewarkAPTS is relatively weak, especially because the definition of the boundary was not in place in 1997 (it still is not formalised) and the palynology of the transition is still not worked out in Tethyan strata (Kürschner in Krystyn et al. 2007a, b). 
Magnetostratigraphy provides a potential correlation tool, but the fundamental correlation problem is obvious; the lower half of the Newark section above the conventional Norian is predominately reverse polarity, and until very recently there have been no comparable dominantly reverse polarity sequences seen in Tethyan sections (Fig. 10). In contrast, the magnetostratigraphic correlation between the Tethyan Norian and the Newark appears fairly secure (Muttoni et al. 2004; Channell et al. 2003). Most of the Tethyan sections examined appear too short to be of much use (Fig. 10), except to help define the lower boundary of the Rhaetian.

Tectonic omission by faults may play a role in the comparison between the Tethyan sections and the Newark. Until the recent work by Muttoni et al. (2010), the only Tethyan section that purportedly spanned the Triassic-Jurassic boundary to the base of the Rhaetian was the Oyuklu section of southwestern Turkey totalling $\sim 29 \mathrm{~m}$ (Gallet et al. 2007). Unfortunately, the base of that section, also the base Rhaetian, is a significant thrust fault that overturns the underlying section. In addition, another fault, not discussed in Galler et al. (2007), bounds the base of the upper three-quarters of the section. This upper interval of mostly normal polarity is thought to extend into Jurassic age strata (although this is based solely on the disappearance of conodonts) and is structurally detached from the lower interval that has slightly more reverse polarity. Comparison of this section with the Newark-APTS is thus problematic.

Muttoni et al. (2010) provide palaeomagnetic polarity stratigraphies for thick Tethyan sections in the southern Alps near Bergamo, Italy totalling $\sim 480 \mathrm{~m}$, more than an order of magnitude thicker than the Oyuklu section (Fig. 10). Both the end-Triassic extinction level and the putative Norian-Rhaetian boundary are present, with the latter defined by the FAD of the conodont species Misikella posthernsteini, defining the base Rhaetian (according to Krystyn et al. 2007a, b) and Misikella hernsteini extending up from the Late Norian Age strata. Perhaps unsurprisingly there are more polarity zones per unit time in the expanded Italian sections (represented by more than one sample) than in the condensed Oyuklu section, and more yet in the putatively correlative and thick Newark section (Fig. 10), which is evidence of omissions in the thinner sections. The argument against this, perfectly plausible on face value, is that the Norian-Rhaetian boundary is placed too low in the Newark section. However, placing that boundary higher in the Newark results in exacerbating the larger number of polarity zones in the Newark compared to the Tethyan Norian sections, given the fact that Gallet et al. $(2003,2007)$ agree with the placement of the Carnian-Norian boundary. Thus, there must be gaps or highly condensed intervals in the Tethyan section relative to the Newark.

A thin Rhaetian section at Steinbergkogel in Austria has been proposed as the GSSP for the base of the Rhaetian (Krystyn et al. 2007a, b). The magnetostratigraphy from this and an adjacent section did not provide a convincing correlation to the Newark basin because of the very few polarity zones present and because of a lack of agreement between adjacent sections. Hüsing et al. (2011) recently reexamined the section at Steinbergkogel, resulting in a polarity stratigraphy with more polarity zones and more convincing correlation to the nearby section. This results in a more reasonable correlation to the Newark as well as the more expanded marine sections at Pizzo Mondello and Silická Brezová (Slovakia) (Fig. 10).

The GSSP for the Norian-Rhaetian boundary has yet to be defined, with two alternative proposed conodont-based options being: (1) the First Occurrence (FO) of Misikella hernsteini; or (2) the first appearance datum (FAD) of Misikella posthernsteini; both fall close to the boundary between Sevatian 1 and Sevatian 2. Hüsing et al. (2011) correlate the base of Sevatian 2 to the top of E16n, falling at 210.1 Ma in the Newark-APTS 2010. Unfortunately, the upper boundary of Sevatian 2, the traditional base of the Rhaetian, has not been located in this section, as the critical ammonites have not been found. The extension of the Rhaetian base from 207.6 Ma to $210 \cdot 1 \mathrm{Ma}$ reflects the inclusion of Sevatian 2 into the Rhaetian. There may be no clear marker of the Sevatian 1-2 boundary in the continental realm. In the Newark basin, Granuloperculatipollis rudis has its first occurrence in the upper part of the lower Passaic-Heidlersburg palynological assemblage (Cornet 1977), consistent with the Newark-APTS 2010.

Palaeomagnetic polarity correlation between the NewarkAPTS and Tethyan Norian seems much more straightforward (Channell et al. 2003; Gallet et al. 2003; Muttoni et al. 2004; Hüsing et al. 2011) than the Rhaetian correlation. Because the astronomical calibration through the section above the Norian and below the latest Rhaetian radioisotopic dates (Pálfy \& Mundil 2006; Schaltegger et al. 2008; Schoene et al. 2010) comprises the only geochronological constraint on the duration of the Rhaetian (and the duration of any putative unconformity), the Newark-APTS 2010 estimated duration of 6.2 Myr for the traditional Rhaetian and 9.7 Myr for the Rhaetian including Sevatian 2 stands. We look forward to testing this hypothesis with radioisotopic ages from ashes and flows in marine sequences.

\section{The Norian is long (18-20 Myr)}

Perhaps the biggest surprise from correlation between the Newark-APTS and marine sections was the realisation that the Norian stage is the longest stage of the Triassic and considerably longer (and starts earlier) than given in several prominent recent geologic time scales (e.g., GTS2004) (Fig. 4). The Carnian-Norian boundary in the Newark basin was originally identified by Cornet (1977) as between the New OxfordLockatong palynoflora and the Lower Passaic Heidlersburg palynoflora (localities S2a in the Walls Island Member of the Lockatong Formation and M6 of member L-M of the Passaic Formation). However, when long marine Tethyan palaeomagnetic polarity sequences became available, this correlation became untenable (Channel et al. 2003; Gallet et al. 2003; Muttoni et al. 2004) and suggested that the Carnian-Norian boundary had to be much lower in the upper Stockton Formation.

In fact, the palynological data are not as discrepant as they might seem. Cornet (1977) used the presence of Camerosporites pseudoverrucatus of the New Oxford-Lockatong palynoflora as indicative of a Carnian age because it is present in the older Chatham-Richmond-Taylorsville palynoflora of undoubted pre-Norian age and becomes rare or absent above the Lockatong Formation. Cornet (1977) used Camerosporites verrucatus, present in Lower Passaic Heidlersburg palynoflora, as an indicator of Norian age, although he later found this taxon in the Lockatong Formation, in a level below locality S2a (Cornet in Olsen \& Flynn 1989). Absent from the New Oxford-Lockatong palynoflora is Camerosporites seccatus, a form common in the European Carnian and in the ChathamRichmond-Taylorsville palynoflora but absent from the Norian of Europe, while Camerosporites verrucatus is common in Norian strata and absent in Carnian age strata (Litwin \& Skog 1991). On face value, based on Camerosporites spp., the Lockatong Formation would seem to be Norian in age. However, such one-taxon palynological correlations are probably not very useful over intercontinental distances and, in fact, the Camerosporites seccatus occurrences in the Chinle, 
long thought to indicate a Carnian age, appear to be Norian as well (see below). There are no tetrapod taxa that by themselves argue for a Carnian age associated with the New Oxford-Lockatong palynoflora.

Kozur \& Weems $(2007,2010)$ define conchostracan zones for the Triassic of eastern and western North America. In the Newark basin they conclude that the Euestheria ovata-E. princetonensis Zone of the Lockatong Formation of the Newark basin (and its correlatives in other Newark Supergroup basins) correlates with Kozur and Weem's Laxitextella freybergi $\mathrm{n}$. sp. in the Germanic basin that they interpret to be Tuvalian (Late Carnian) in age, based on the shared presence of Euestheria hausmanni. Note however that the Newark conchostracan zone is correlated to the Germanic basin by a shared taxon, and the Germanic basin conchostracan zone is then correlated to the Alpine standard stages by a correlation web. Thus, we are a least three steps away from correlation with the Alpine Triassic. Because there are no magnetostratigraphies or radioisotopic ages from the putative Tuvalian of the Germanic basin, there are no available biostratigraphically-independent tests of this correlation. However, the Lockatong Formation is correlative with the lower Chinle Formation (Blue Mesa and Bluewater Creek Members), based on palaeomagnetic polarity stratigraphy (see above: Steiner \& Lucas 2000), palynology (Litwin et al. 1991), vertebrate biostratigraphy (Lucas 1990; Lucas \& Huber 1993) and shared conchostracans (Kozur \& Weems 2008); as discussed above and in more depth below, the lower Chinle has produced $\mathrm{U}-\mathrm{Pb}$ ages from ashes that are too young to be Carnian (Fig. 15; see section 9 below). This is a prima facie falsification of the conchostracan biostratigraphic argument, and the statement in Kozur \& Weems (2007) that "(t)hese conchostracan faunas show that all paleomagnetic correlations so far made between the Newark Supergroup and the Tethys region are wrong" should be viewed in that light.

Based on the age of the Triassic-Jurassic boundary of 201.3 Ma (first appearance of Psiloceras spelae in Schoene et al. 2010) and the early Norian date of $225 \pm 3 \mathrm{Ma}$ (Gehrels et al. 1987), which is supported by a late Carnian U-Pb date of $230 \cdot 9 \pm 0 \cdot 33 \mathrm{Ma}$ (Furin et al. 2006), the Norian plus early to middle Rhaetian cannot be less than $\sim 23 \mathrm{Myr}$ or more than $\sim 29 \mathrm{Myr}$ in duration, constraints that are fully consistent with the Newark-APTS 2010. If $\sim 6 \mathrm{Myr}$ is accepted as the duration of the pre-late Rhaetian, pre-end-Triassic extinction, the Norian should be between $\sim 17$ to $23 \mathrm{Myr}$ long, easily allowing the Newark-APTS 2010 duration of $20 \cdot 1 \mathrm{Myr}$ for the Norian if the traditional definition of the Rhaetian is used, or 17.6 Myr if Sevatian 2 is included in the Rhaetian (see section 5 above). If the Rhaetian proves shorter, the Norian would be correspondingly longer. The present authors are not aware of any quantitative data or convincing biostratigraphic data contradicting these assessments.

\section{The Carnian is short (7 Myr)}

The base of the Carnian is estimated at $235 \mathrm{Ma}$ by Muttoni et al. (2004). Although the base of the Carnian has yet to be formally defined and there are no direct dates, the age of $235 \mathrm{Ma}$ is completely consistent with $\mathrm{U}-\mathrm{Pb}$ ages from ashes and intrusions in marine Tethyan Ladinian age strata (Mundil et al. 1996; Brack et al. 1997, 2005; Pálfy et al. 2003; Furrer et al. 2008). If the Carnian-Norian boundary is at $228 \pm 2 \mathrm{Ma}$ based on Newark-APTS 2010, and the base of the Carnian is at $235 \pm 2$ (Brack et al. 2005), the duration of the Carnian is $\sim 74$ Myr. Taking the maximum age for the base of the Norian of $\sim 230$ (based on the age of Furin et al. 2006) the Carnian could be a short as $3 \mathrm{Myr}$.

\section{The rest of the Triassic is short $(\sim 17.5 \mathrm{Myr})$}

A corollary to the age of the base of the Carnian at $\sim 235 \mathrm{Ma}$ is that the rest of the Triassic is quite short, shorter in fact than the Norian. The base of the Triassic (GSSP) is at $\sim 252.5 \mathrm{Ma}$ (see review in Metcalfe \& Isozaki 2009), and therefore the rest of the Triassic (Early plus Middle Triassic) must be $\sim 17.5$ Myr. The duration of the Early Triassic at only 5.5 Myr is better constrained than that of the Middle Triassic (Metcalfe \& Isozaki 2009). This reemphasises the very long duration of the Norian at $\sim 22 \mathrm{Myr}$ and of the Late Triassic at $34 \mathrm{Myr}$, which constitutes $2 / 3$ of Triassic time.

\section{The Chinle and Dockum may be entirely Norian and Rhaetian}

Traditionally, the Chinle Formation of the Colorado Plateau and environs and the equivalent Dockum Group of the High Plains (together grouped by Lucas 1993 in the Chinle Group) (Fig. 13) have been correlated with nearly the entire Late Triassic. Lucas (1993) summarised and revised the biochronology as it was understood at the time (Figs 13, 14) and recognised four tetrapod faunachrons (from oldest to youngest A, B, C, D) that he correlated to the European standard stages. Martz (2008) provides a review of the older literature that established the basis for recognising these assemblages. Lucas \& Hunt (1993) gave these faunachrons names, Otischalkian, Adamanian, Reveultian and Apachean, respectively. The Otischalkian plus Adamanian were correlated to the Carnian, and the Reveultian and Apachean were correlated to the Norian, that at the time included the Rhaetian. The correlations were based upon key tetrapod taxa that are supposedly shared with sequences in Europe of unquestioned age. These tetrapod correlations were supported by the palynological zonations and correlations of Litwin \& Skog (1991), Litwin et al. (1991) and Cornet (1993), as well as by the floral zones of Ash (1980, 1987), although there has been significant criticism (e.g., Langer 2005; Rayfield et al. 2005, 2009; Irmis et al. 2010). Later, Lucas $(1998,2010)$ correlated the Apachean with the re-recognised Rhaetian, stressing that part could still be Norian which otherwise was just represented by the Reveultian. Furthermore, in the western US, the AdamanianReveultian and Reveultian-Apachean boundaries were interpreted as unconformities and sequence boundaries ( $\mathrm{Tr}-4, \mathrm{Tr}-5)$ by Lucas (1993) and correlated to marine sequence boundaries in Nevada by Lucas (1991), Lucas \& Huber (1994) and Marzolf (1993). These interpretations remain in wide use (e.g. Cleveland et al. 2007, 2008), despite being questioned (e.g. Woody 2006).

Late Triassic faunachrons of the western United States were correlated to a similar set of faunachrons developed for eastern North America (Newark Supergroup) by Huber et al. (1993) and correlated globally (Lucas 1998; Lucas \& Huber 2003) (Fig. 14). The palynology of the Newark Supergroup seemed to be at least broadly compatible with this correlation and with correlation to the European Triassic. The correlations between the eastern and western North American faunachrons were also corroborated by palaeomagnetic polarity stratigraphy from Adamanian and Reveultian strata in the Colorado Plateau (Steiner \& Lucas 2000: see section 2.1). These Newark Supergroup faunachrons were used in all the pre-2003 versions of the Newark-APTS. However, with the correlations to the marine sections by Muttoni et al. (2004) and Channell et al. (2003), it became clear that correlation of both the western and eastern faunachrons with the European Triassic and South American Triassic required serious revision (also see Schultz 2005 and Langer 2005). Correlation between the western and 


\begin{tabular}{|c|c|c|c|c|c|c|c|}
\hline $\begin{array}{c}\text { Stage } \\
\text { or } \\
\text { Age }\end{array}$ & $\begin{array}{c}\text { Tetrapod } \\
\text { faunachrons: } \\
\text { Lucas, } 1993\end{array}$ & $\begin{array}{c}\text { Land } \\
\text { Vertebrate } \\
\text { Ages: Lucas } \\
\text { \& Hunt, 1993 }\end{array}$ & $\begin{array}{c}\text { Fish } \\
\text { Assemblages }\end{array}$ & $\begin{array}{l}\text { Floral } \\
\text { Zone }\end{array}$ & $\begin{array}{l}\text { Palynofloral } \\
\text { Zone }\end{array}$ & $\begin{array}{c}\text { Calcareous } \\
\text { Microfossil } \\
\text { Assemblages }\end{array}$ & $\begin{array}{l}\text { Unionid } \\
\text { Abundance }\end{array}$ \\
\hline$\frac{Z}{\sigma}$ & & ZESOSISOA & $\begin{array}{c}\text { middle } \\
\text { Norian } \\
\text { assemblage }\end{array}$ & \multirow[t]{2}{*}{$\begin{array}{l}\text { Sanmiguella } \\
\text { floral } \\
\text { zone }\end{array}$} & \multirow{2}{*}{$\begin{array}{l}\text { upper } \\
\text { Petrified } \\
\text { Forest } \\
\text { palynofloral } \\
\text { zone }\end{array}$} & \multirow[t]{2}{*}{$\begin{array}{c}\text { small } \\
\text { Darwinula } \\
\text { assemblage }\end{array}$} & \multirow[t]{2}{*}{$\begin{array}{l}\text { unionoids } \\
\text { low } \\
\text { abundance }\end{array}$} \\
\hline $\bar{Z}$ & & Revueltian & $\begin{array}{c}\text { early } \\
\text { Norian } \\
\text { assemblage }\end{array}$ & & & & \\
\hline & 8 & 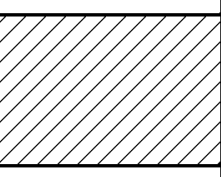 & 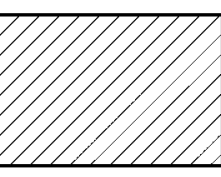 & 787878 & DOPJPIS & 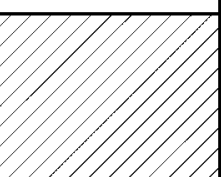 & 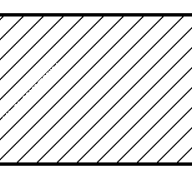 \\
\hline \multirow[t]{2}{*}{$\frac{Z}{2}$} & B & Adamanian & $\begin{array}{c}\text { late } \\
\text { Carnian } \\
\text { assemblage }\end{array}$ & $\begin{array}{l}\text { Dinophyton } \\
\text { floral } \\
\text { zone }\end{array}$ & $\begin{array}{l}\text { lower } \\
\text { Petrified } \\
\text { Forest } \\
\text { palynofloral } \\
\text { zone }\end{array}$ & 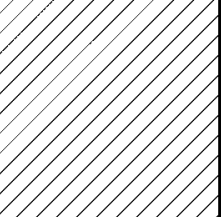 & \multirow[t]{2}{*}{$\begin{array}{l}\text { unionoids } \\
\text { high } \\
\text { abundance }\end{array}$} \\
\hline & $\mathrm{A}$ & Otischalkian & & $\begin{array}{l}\text { Eoginkoites } \\
\text { floral zone }\end{array}$ & $\begin{array}{l}\text { Temple Mt. } \\
\text { palynofloral } \\
\text { zone }\end{array}$ & $\begin{array}{c}\text { large } \\
\text { Darwinula } \\
\text { assemblage }\end{array}$ & \\
\hline
\end{tabular}

Figure 13 Chinle and Dockum biozonation from Lucas (1993) and Lucas \& Hunt (1993) as they were first formulated. Hachures indicate either a hiatus or lack of data.

\begin{tabular}{|c|c|c|c|c|c|c|c|c|c|}
\hline$\overline{\text { SER }}$ & STAGE & SBST & $\begin{array}{l}\text { South American } \\
\text { LVF }\end{array}$ & Argentina & Brazil & Newark LVF & \multicolumn{2}{|c|}{ Chinle LVF \& Sub-LVF } & Greenland \\
\hline \multirow{2}{*}{ 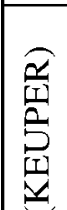 } & $\stackrel{T}{2}$ & & \multirow{3}{*}{ Coloradian } & \multirow{3}{*}{$\stackrel{\text { Los }}{\text { Colorados Fm }}$} & & \multirow{2}{*}{ Cliftonian } & \multicolumn{2}{|c|}{ Apachean } & \\
\hline & \multirow{2}{*}{$\begin{array}{l}Z \\
\vdots \\
\text { Z } \\
\mathbf{Z} \\
Z\end{array}$} & & & & & & & Lucianoan & \\
\hline \multirow{5}{*}{ 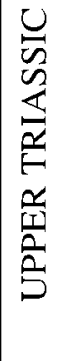 } & & & & & & Neshanician & Kevuetirall & Barrancan & $\begin{array}{l}\text { Fleming } \\
\text { Fjord Fm }\end{array}$ \\
\hline & \multirow{4}{*}{ 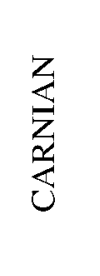 } & \multirow{3}{*}{ 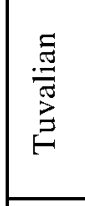 } & \multirow{2}{*}{ Ischigulastian } & \multirow{2}{*}{\begin{tabular}{|c|} 
Ischigualasto \\
Fm
\end{tabular}} & Caturrita Fm & \multirow{2}{*}{ Conewagian } & \multirow{2}{*}{ Adamanian } & Lamyan & \\
\hline & & & & & \multirow{2}{*}{$\begin{array}{l}\text { Santa Maria } \\
\text { Fm }\end{array}$} & & & St. Johnsian & \\
\hline & & & & & & Sanfordian & \multicolumn{2}{|c|}{ Otischalkian } & \\
\hline & & Jul & & & & & & & \\
\hline
\end{tabular}

Figure 14 Conventional correlations of faunachrons and dinosaur-bearing formations of South America, eastern United States, western United States and Greenland based on Lucas (2010), Lucas et al. (2007), Hunt et al. (2005) and Heckert \& Lucas (2006). Hachures indicate either a hiatus or lack of data.

eastern North American faunachrons was largely unaffected, however, because both the Adamanian and the Conewagian can be correlated to the Lower Norian independently via $\mathrm{U}-\mathrm{Pb}$ dates and astrochronology and magnetostratigraphy.

The palaeomagnetic polarity stratigraphy of Steiner \& Lucas (2000) does, however, require some modification based on interpretations of lithostratigraphic correlations across Petrified Forest National Park. Including that of Steiner \& Lucas (2000), there have been at least ten attempts (reviewed in Martz \& Parker 2010) at correlating the southern sections of the park, where the lower part of the polarity section and the upper part of the sections in the northern outcrops were sampled for palaeomagnetic stratigraphy. These attempts have produced results that are grossly similar but irreconcilable in detail, an indication that such correlations are far from straightforward. Martz \& Parker (2010) conclude that Steiner \& Lucas (2000), among others, mis-correlated sandstones from the north and south end of the park, with the result that about one third of the total exposed park stratigraphy was not sampled palaeomagnetically corresponding to most of what is now included in the Sonsela Member (Fig. 15). However, this revised stratigraphy only requires a modest change in the palaeomagnetic correlation to the Newark basin.

Taken at face value, the palaeomagnetic correlations of Steiner \& Lucas (2000), coupled with those of Muttoni et al. (2004) and Channell et al. (2003), suggest there may be little or 
Steiner \& Lucas 2000

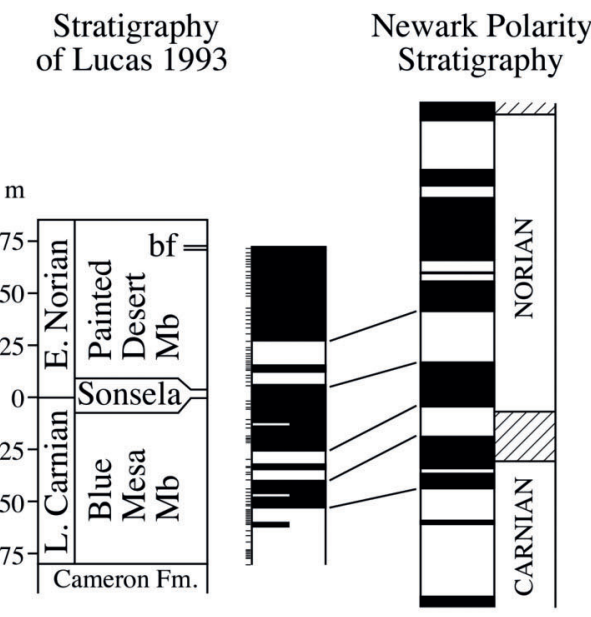

Revised Correlation

Alternative PFNP Stratigraphy

Newark Astrochronology

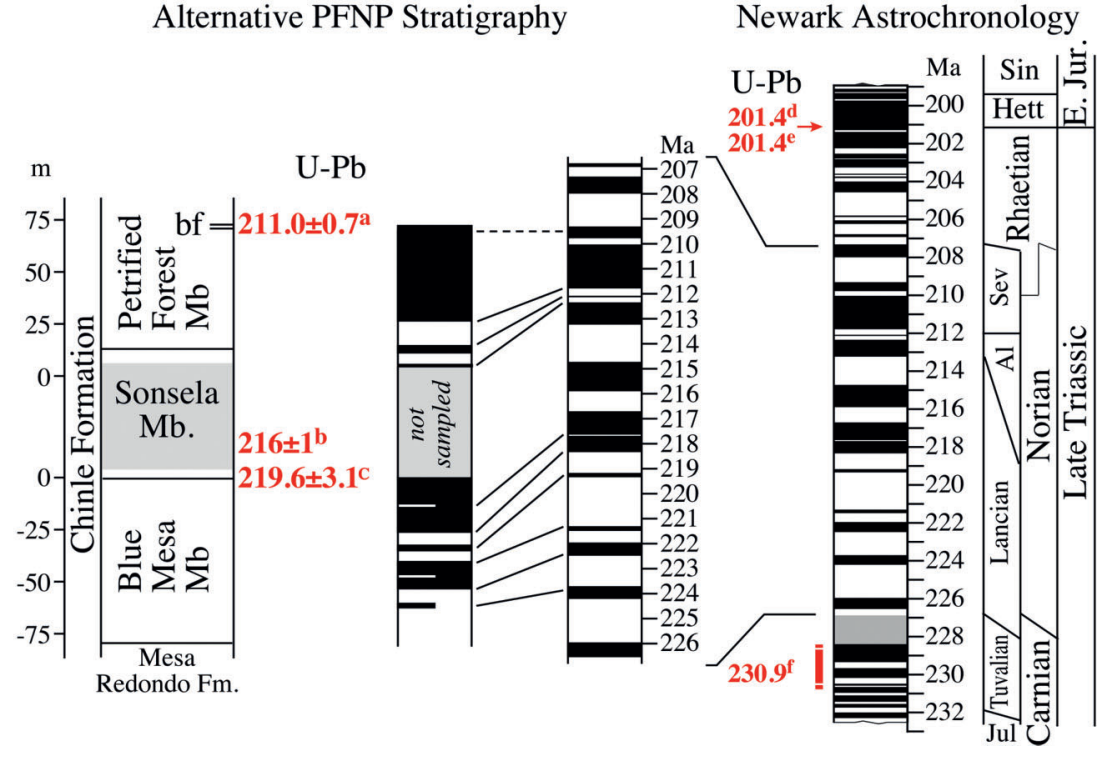

Figure 15 Comparison of stratigraphy and palaeomagnetic data from the Chinle Formation of the Petrified Forest National Park and the Newark-APTS 2010, and implications for correlation of using a more recent alternative stratigraphy of the Sonsela Member (from Martz \& Parker 2010). Under 'Revised Correlation', U-Pb $\left({ }^{206} \mathrm{~Pb} /{ }^{238} \mathrm{U}\right)$ dates on zircons are: $\mathrm{a}$ and $\mathrm{b}$ are $c 1$ and $c 2$ of Table $1 ; \mathrm{c}$ is $c 3$ of Table 1 from Mundil \& Irmis (2008), revised to correlate with the basal Sonsela Member according to Ramazani et al. (2010); d, e, and f correspond to $n 1, m 4, m 5$ and $m 1$, respectively of Table 1 . The Black Forest bed is indicated as 'bf' in the Petrified Forest sections.

no Carnian age continental strata in the western United States, and that the strata previously thought to be Carnian is Early Norian in age. This interpretation is in agreement with $\mathrm{U}-\mathrm{Pb}$ dates from detrital zircons from the lower Chinle Formation of Petrified Forest National Park in Arizona and the surrounding area (e.g., Mundil \& Irmis 2008; Dickinson \& Gehrels 2009; Heckert et al. 2009; Ramezani et al. 2010) which are all younger than the $\mathrm{U}-\mathrm{Pb}$ date from Early Norian marine strata from southern Alaska of $225 \pm 3$ (Gehrels et al. 1987) and the only date from marine Late Carnian strata of 230.91 \pm 0.33 Ma (Furin et al. 2006; Ramezani et al. 2009). These Chinle dates are closely comparable to several as yet unpublished ages by Ramezani et al., quoted in Kozur \& Weems (2010). Further analysis of the abundant reworked ashes in the Chinle will allow a robust test of this correlation (Fig. 15) (c.f., Irmis \& Whiteside 2010).

Thus, the Adamanian-Reveultian boundary, long thought to correlate with the Tethyan Carnian-Norian boundary, is actually a mid-Norian age close to, and may be correlative to, the Tethyan Lancian-Alunian substage boundary (Figs 4, 16), however vaguely that may be defined based on interpolation between the secure parts of marine biostratigraphy (see Irmis et al. 2010). This falls at about 213-216 Ma in Newark-APTS 2010 at the Lower Passaic-Heidlersburg palynofloral zone boundary (also originally thought to mark the CarnianNorian boundary), an age compatible with the $\mathrm{U}-\mathrm{Pb}$ ages from the Chinle itself. This age is also within error of the Manicouagan impact structure in Quebec (215.5 Ma, Ramezani et al. 2005; 215.56 $\pm 0 \cdot 05 \mathrm{Ma}$, Ramezani cited by van Soest et al. 2009). A plausible hypothesis is that the faunal and floral turnover seen in the Chinle, Newark, and in marine environments at between 213-216 Ma, actually correlated with the effects of the Manicouagan impact (e.g. Dunlavey et al. 2009; Parker \& Martz 2011). Previous assessments that there is no sign of any biotic effect of Manicouagan (e.g. Hallam 2002; Tanner et al. 2004; Walkden \& Parker 2008; Heckert et al. 2009; Tackett et al. 2009) are attributable to a lack of registry between the strata containing the palaeobiological information and of an adequate geochronologic time scale that overlaps with Manicouagan.

The Otischalkian faunachron, which is supposed to be the oldest of the eastern US Late Triassic faunachrons, may also be Early Norian in age. The type assemblage in the Cooper Canyon Formation near 'Otis Chalk' (Howard County, Texas) lies rather high in the local section and has an ambiguous relationship with the rest of the Dockum Formation (Martz 2008). Martz (2008) also argues that there is so much faunal overlap between the Otischalkian and Adamanian assemblages that they cannot be practically distinguished (also see Langer 2005). Otischalkian assemblages probably pertain to the basal Adamanian.

The oldest strata in the Chinle Formation on the Colorado Plateau and environs is the Shinarump Member and its equivalents, which because of their generally coarse nature have not provided much in the way of tetrapod remains. Detrital zircons analysed by Dickinson \& Gehrels (2009) by LA-TIMS yield ages consistent also with an Early Norian age. The youngest single zircon grains from three different localities in the Shinarump Member yield ages of $215 \pm 7 \mathrm{Ma}$, $222 \pm 3 \mathrm{Ma}$, and $224 \pm 6 \mathrm{Ma}$, on the young side of the $227 \cdot 7 \pm 0.7 \mathrm{Ma}$ of the Carnian-Norian boundary in NewarkAPTS 2010, although the averages of the youngest populations tend to give older ages, as would be expected given that the Shinarump Member is a basal conglomerate. Martz (2008) noted that Gehrels \& Dickinson (1995) and the pioneering studies of Riggs et al. (1996) used detrital zircons to correlate the Shinarump Member with the marine Auld Lang Syne Group, which is early Norian in age, which completely agrees with the newer detrital zircon ages. Detrital zircons from the Santa Rosa Formation of the Dockum, which is the basal unit, at least locally, was also correlated to the Auld Lang Syne Group by Riggs et al. (1996), although the youngest single zircon crystals reported by Dickinson \& Gehrels (2009) are pre-Triassic and hence cannot reflect the depositional age. CA-TIMS ages are needed for a definitive estimate of maximum age, however. Nonetheless, it is difficult to argue that 


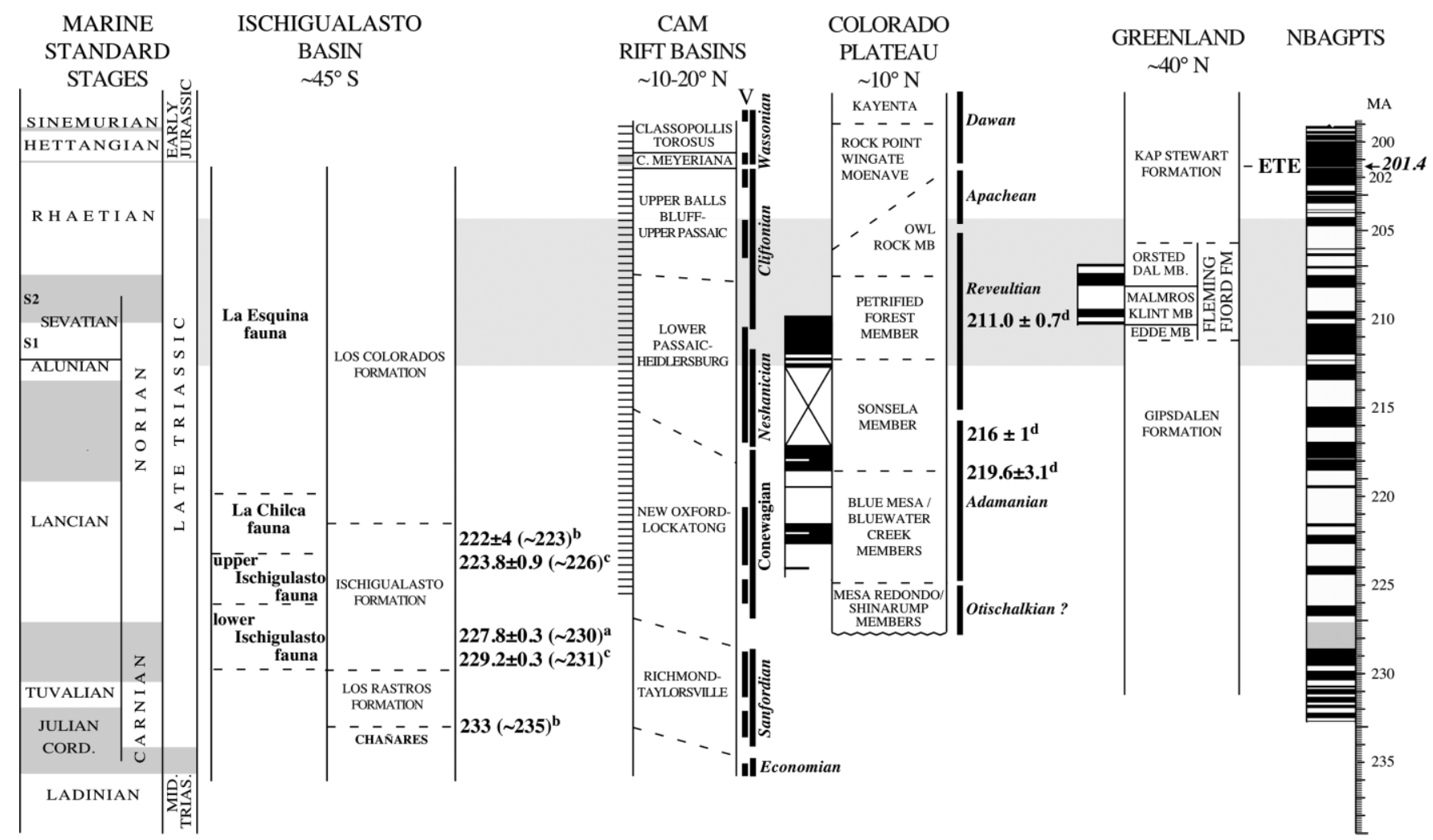

Figure 16 Revised correlations of important Triassic tetrapod assemblages based on the Newark-APTS 2010. The black and grey vertical bars represent the ranges of dates associated with the Ischigualasto basin; those in parentheses are ${ }^{40} \mathrm{Ar} /{ }^{39} \mathrm{Ar}$ dates and the dates in parentheses are 'corrected' to the assumed equivalent $\mathrm{U}-\mathrm{Pb}$ ages. Diagonal dashed lines indicate the temporal uncertainty of the boundaries imposed by the uncertainty in accuracy of the ${ }^{40} \mathrm{Ar} /{ }^{39} \mathrm{Ar}$ versus U-Pb=corrected dates relative to the Newark-APTS 2010. For the Colorado Plateau, the ages are ${ }^{206} \mathrm{~Pb} / 235 \mathrm{U}$ ages from Figure 9. Sources of the ages are: ${ }^{\text {ankogers }}$ et al. 1993; ${ }^{b}$ Shipman 2004 and Tabor et al. 2006; ${ }^{\mathrm{c}}$ Martinez et al. 2011; ${ }^{\mathrm{d}}$ Figure 9. Palaeolatitudes are representative of the time interval represented by the grey band in which basal sauropodomorphs ('prosauropods') are abundant at the high latitudes and absent at low latitudes; latitudes are extrapolated from Kent \& Tauxe (2005). Abbreviations: $\mathrm{CORD}=$ Cordevolian; $\mathrm{FM}=$ Formation; $\mathrm{MB}=$ Member; $\mathrm{V}=$ intervals (black lines below) with multiple tetrapod skeletal remains.

there is positive evidence from the $\mathrm{U}-\mathrm{Pb}$ dates that the depositional age of any of the Chinle Formation or Dockum Group is Carnian (Fig. 16). Single crystal CA-TIMS ages should go far to remove remaining ambiguity. The critical implication of these correlations is that all of the Late Triassic fossil material from the western United States is Norian or younger in age and the major faunal and floral changes that are seen may be correlative with the Manicouagan impact, and that the Chinle-Dockum faunas remain relatively similar from the Otischalkian though the Apachean and plausibly right up to the end-Triassic extinction event.

\section{The Ischigualasto is older than the Chinle but still at least mostly Norian: there may be no Carnian dinosaurs}

The Ischigualasto Formation of the Ischigualasto-Villa Union basin, northwestern Argentina, is famous for its rich Triassic assemblages, especially early dinosaurs, amongst which are arguably the oldest (e.g. Langer 2005). As with other wholly continental assemblages, its age has proven problematic despite the presence of dated and datable ashes. As pointed out by Langer (2005), because of its distinctive tetrapod assemblage Bonaparte (1966) coined the term Ischigualastian that was later co-opted as a faunachron (Lucas 1998). Lucas (1998), Heckert \& Lucas (2002a), and Lucas \& Huber (2003) correlated the Ischigualastian to the Adamanian and the Conewagian and hence the Carnian.
A ${ }^{40} \mathrm{Ar} /{ }^{39} \mathrm{Ar}$ date of $227 \cdot 8 \pm 0 \cdot 3 \mathrm{Ma}$ from the 'Herr Toba' ash bed near the base of the formation (Rogers et al. 1993) has provided a critical constraint on the age of the unit and bears on the age of all of the South American Triassic assemblages (e.g. Langer 2005). The date of $227 \cdot 8 \pm 0 \cdot 3 \mathrm{Ma}$ was rather uncritically considered a strong Carnian age at the time using the available compiled time scales (e.g. Gradstein \& Ogg 1996) as well as Newark-APTS 1999A (Kent \& Olsen 1999; Muttoni et al. 2004). However, at face value, it now falls nearly on the Carnian-Norian boundary of Newark-APTS 2010 which, because virtually all the Ischigualasto fossils fall above the ash bed, makes most of the Ischigualastian faunal assemblages Norian in age. Other ${ }^{40} \mathrm{Ar} /{ }^{39} \mathrm{Ar}$ dates from higher in the Ischigualasto have been cited without supporting data but range from 218 to $223 \mathrm{Ma}$ (Shipman 2004; Tabor et al. 2006; Currie et al. 2009). At face value these are also Norian ages (Fig. 16).

Recently, Martinez et al. (2011) provided two new ${ }^{40} \mathrm{Ar} /{ }^{39} \mathrm{Ar}$ dates from the Ischigualasto Formation: one is $229 \cdot 2 \pm 0 \cdot 3$, a recalculation, with different constants, of the Herr Toba bentonite date of Rogers et al. (1993) of $227 \cdot 8 \pm 0 \cdot 3$; the other is from an ash near the local top of the formation $(610 \mathrm{~m}$ above the Herr Toba bed) with a date of $223.8 \pm 0 \cdot 9$. These nominal ages are all younger than the Late Carnian marine date of Furin et al. (2006).

Clearly, the most relevant is the older date of Rogers et al. (1993) and Martinez et al. (2011) and it requires a closer look. It has become standard when comparing ${ }^{40} \mathrm{Ar} /{ }^{39} \mathrm{Ar}$ and $\mathrm{U}-\mathrm{Pb}$ ages to 'correct' the former age based on an apparent shift 
towards younger values in the ${ }^{40} \mathrm{Ar} /{ }^{39} \mathrm{Ar}$ compared to the U-Pb systems (Min et al. 2000; Mundil et al. 2006). Irmis \& Mundil (2008) also did this (recalculating to revised ${ }^{40} \mathrm{Ar} /{ }^{39} \mathrm{Ar}$ constants) and obtained a U-Pb-equivalent age of $231.4 \mathrm{Ma}$ (the same $-231 \cdot 4 \pm 0 \cdot 3 \mathrm{Ma}$ as published by Martinez et al. (2011), which is within error of the Furin et al. (2006) date of $230.91 \pm 0.33$ from an ash interbedded with latest Carnian age Metapolygnathus nodosus zone limestones (Tuvalian 3), when the uncertainties of the ${ }^{40} \mathrm{Ar} /{ }^{39} \mathrm{Ar}$ age are propagated. The criterion that must be met for any sequence to be considered as Carnian is that it must be securely older than $231 \mathrm{Ma}$ in age; this criterion is not even met for the Herr Toba date after corrections amounting to $3.6 \mathrm{Myr}$. In addition, because the Herr Toba ash is so low in the section, most of the overlying section of Ischigualasto Formation is likely to be at least in part Norian in age and, indeed, the loosely 'corrected' ages from high in the formation give a range of 220-226 Ma, which is still Norian in the Newark-APTS 2010. Even the 'corrected' age for the ash from the upper Ischigualasto Formation $(225 \cdot 9 \pm 0 \cdot 9)$ is within error of the $225 \pm 3$ (Gehrels et al. 1987) early Norian date. Accordingly, all of the ages fall within the uncertainty of the marine Carnian-Norian boundary and, therefore, there is significant doubt about how much if any of the Ischigualasto is of Carnian age. This discussion applies to the biostratigraphically correlative Ischigualastian assemblages of Brazil as well (e.g. Martinez et al. 2011). Clearly, modern $\mathrm{U}-\mathrm{Pb} \mathrm{CA}$-TIMS dates are needed from this succession to compare with dates from the marine Triassic.

Although there can be little doubt that most if not all Chinle Formation assemblages are significantly younger as argued by Langer (2005) and Irmis \& Mundil (2008) (Fig. 16), the available radioisotopic constraints on the Ischigualasto do not support correlation with the Adamanian or with any part of the Chinle or Dockum (Irmis \& Mundil 2008). Taken at face value and accepting Newark-APTS 2010, this would make the oldest dinosaurs in the world Norian in age; there would be no known dinosaurs securely known as Carnian. This does not diminish the fact that the Ischigualasto and correlative units in Brazil do contain the oldest known dinosaurs.

Both Rogers et al. (1993) and Martinez et al. (2011) document a disappearance of dinosaurs and rhynchosaurs in the middle of the formation and a $100 \%$ change into the overlying upper Los Colorados Formation. The age of the later transition within the Late Triassic is essentially unknown beyond that it should be post-early-Norian and pre-Jurassic. If the older part of the Ischigualasto Formation is of Carnian age the faunal break could be correlate to the marine CarnianNorian boundary, but because dinosaurs are completely absent thus far from the upper Ischigualasto Formation but are clearly present in the overlying Los Colorados Formation, it is impossible to assess whether this represents a local ecological, a taphonomic, or a taxonomic turnover. Assessing the significance of this faunal change relative to global patterns requires appropriate, independent geochronological data, which is thus far lacking.

\section{There is dramatic provinciality in the Late Triassic}

In attempts to correlate among various assemblages globally, there is a tendency to focus on taxonomic similarity and deemphasise geographic differences in the struggle to temporally seriate assemblages. However, there are geographic differences that reflect more than sampling differences. The fact that there were strongly differentiated faunal provinces in the Late Triassic seems odd because of the lack of water

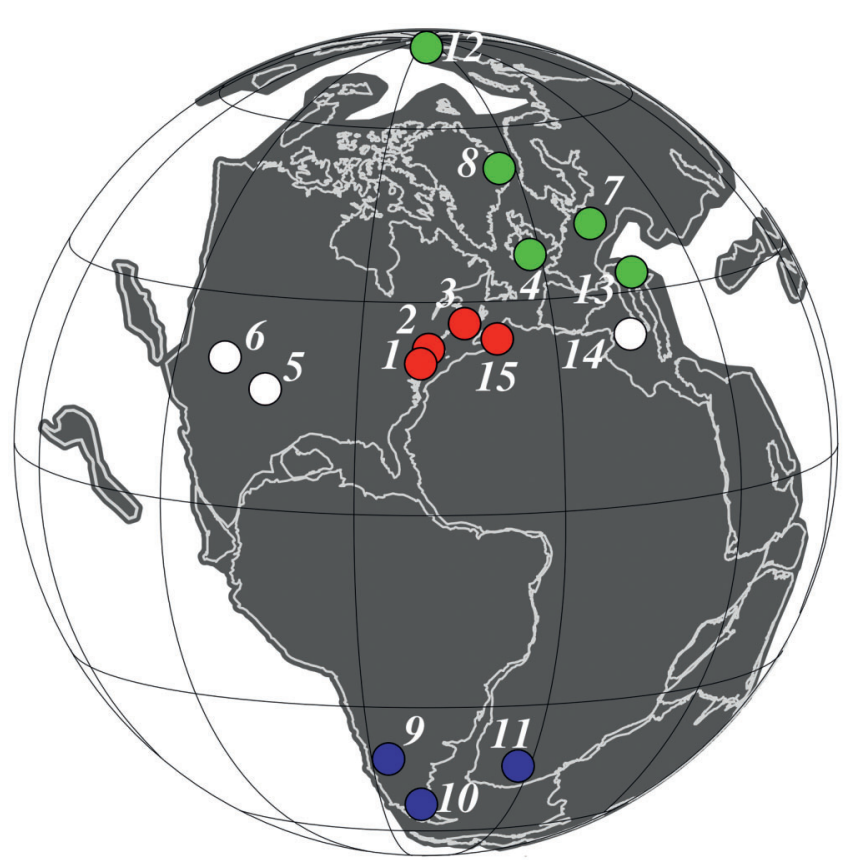

Figure 17 Distribution of the main localities discussed in text on a map of Pangea at about the time of the ETE $(\sim 201.4 \mathrm{Ma})$. Red localities are those in which vesicate pollen taxa (e.g., Patinasporites densus) are present to the ETE; green localities are those where vesicate pollen taxa disappear much earlier or are absent and Rhaetipollis is present to the Triassic-Jurassic boundary; blue localities are those with the Ipswich-type sporomorph assemblages and Dicroidium-dominated macroflorules; white localities are those where pollen has not been recovered from strata close to and below the ETE. Localities: $1=$ Newark basin, USA; $2=$ Hartford basin, USA; $3=$ Fundy basin, maritime provinces, Canada; $4=\mathrm{St}$ Audrie's Bay in the Bristol Channel basin, England; $5=$ Dockum Group, Palo Duro basin, Texas and New Mexico, USA; 6= Chinle Formation, Colorado Plateau, western USA; $7=$ Germanic basin, Germany; $8=$ Fleming Fjord Formation, Jameson Land basin, East Greenland; 9=Ischigualasto and Los Colorados formations, Argentina; 10=Laguna Colorada Formation, Patagonia, Argentina; 11=Elliot and Clarens formations, Ladysmith, South Africa; $12=$ northern Middle Siberia, Russia; 13=Eiberg basin (including Kuhjoch), Austria; 14=Pizzo Mondelo, Italy; 15=Argana and Central High Atlas basins, Morocco. Reconstruction courtesy of C. Scotese.

barriers in Pangea. Nonetheless Olsen \& Galton (1984) and Cornet \& Olsen (1985) recognised clear Late Triassic faunal provinces that tracked to some extent floral provinces (e.g. Dolby \& Balme 1976; Artabe et al. 2003) and that such provinces were a major impediment to biostratigraphic correlation (see also Irmis et al. 2010).

This provinciality can be shown by considering two regions (Fig. 17): (1) the tropical Chinle-Dockum assemblages that are of Norian-Rhaetian age; and (2) the Germanic basin type assemblages, known from Central Europe and Greenland of Carnian-Rhaetian age. Both areas have produced a wealth of material and both assemblages have aquatic and fully terrestrial components. There are some common elements at low taxonomic levels, although these tend to be uncommon and in some cases very ambiguous. More conspicuous than the similarities are the differences. In the Germanic assemblages, basal sauropodomorph ('prosauropod') dinosaurs (especially Plateosaurus), plagiosaurid temnospondyl amphibians and the temnospondyl Cyclotosaurus are the most common tetrapods. None of these taxa are known from the Late Triassic of North America. This pattern is reflected in the phenetic grouping of Germanic, Triassic age assemblages with Early Jurassic assemblages rather than with the coeval North American assemblages (Holtz et al. 2004). Support for this provinciality has been provided by very recent cladistic biogeographic analysis 
of Ezcurra (2010). In addition, an interesting aspect of the provinciality is that during the Late Triassic, the higher latitudes tend to have similar faunas, showing that dispersal must have been possible, even though a low latitude province persisted in between (Olsen \& Galton 1984; Ezcurra 2010).

It is necessary to have an independent way of assessing age when comparing different areas with unknown biogeographic patterns. We can do this for the Triassic by comparing different assemblages correlated on the basis of nonbiostratigraphic criteria, namely magnetostratigraphic polarity stratigraphy (Figs 16, 17). There is magnetostratigraphy for Germanic type assemblages in the Fleming Fjord Formation of Greenland (Kent \& Clemmensen 1996). The faunal assemblages from this sequence have been described largely by Gatesy et al. (1999) and Jenkins et al. (1993, 1994, 1997, 2001, 2008). The most abundant tetrapods from the Fleming Fjord are Gerrothorax and Plateosaurus. Based on the paleomagnetic polarity correlation, the relatively high-latitude Fleming Fjord Formation correlates to the upper Petrified Forest Member and probably to the lower Owl Rock Member of the Chinle Formation and, based on the U-Pb and ${ }^{40} \mathrm{Ar} /{ }^{39} \mathrm{Ar}$ ages from the Chinle and Ischigualasto formations, to part of the upper Los Colorados Formation (La Esquina Fauna, Bonaparte 1982) (Fig. 16), although this hypothesis requires testing by palaeomagnetic data from the Los Colorados Formation itself. The tropically located Reveultian and possible lower Apachean Chinle assemblages, based on abundant bones, completely lack plagiosaurid amphibians, including Gerrothrorax, and sauropodomorphs, including Plateosaurus. Plagiosaurid amphibians are again absent from the Los Colorados Formation, but sauropodomorphs are abundant (see review of Arcucci et al. 2004). In fact, for the Germanic assemblages in general, there is greater similarity through time from the Carnian through the Rhaetian than between any specific time and North America (as also noted by Ezcurra 2010). Likewise, the Chinle Formation and Dockum Group assemblages show continuity in time in overall composition and little similarity to the Germanic assemblages.

Similarly, Martinez et al. (2011) show that dinosaurs comprise a significant component (up to $33 \%$ of individuals) in the lower Ischigualasto Formation that was deposited at even higher southern palaeolatitudes than the overlying Los Colorados Formation. Regardless of these assemblages Carnian or Norian age, dinosaurs are unequivocally rare in assemblages that are broadly correlative (Early Norian and Late Carnian age) in tropical Pangea.

Thus, there are clear geographic provinces apparently tracking latitude to a first approximation. However, these provinces were not isolated, because recent cladistic analyses of both sauropodomorphs (Pol 2005; Upchurch et al. 2007; Yates et al. 2009) and early theropods (e.g. Nesbitt et al. 2009b) show no coherent mapping between geography and cladistic relationships, indicating that at least some migration between provinces occurred. These points have been mentioned (Irmis et al. 2007b; Irmis \& Mundil 2008; Nesbitt et al. 2009b; Ezcurra 2010), and are highlighted in the present paper, because in order to see the geographic patterns that are present it is necessary to have clear non-biostratigraphic means of correlation. The tendency otherwise is to temporally seriate the assemblages in an attempt to minimise the faunal differences resulting in a synthetic, but inaccurate, biochronology.

It should come as no surprise that other groups of organisms show provinciality in the Late Triassic. The provinciality of sporomorphs has already been alluded to, but macrofossil plants also show large-scale geographic differences (Fig. 17). The most obvious of these is the Dicroidium-Thinnfeldia domain in the southern hemisphere (Olsen \& Galton 1984;
Dobruskina 1993; Artabe et al. 2003), and although there are sporadic reports of rare members of this assemblage in the northern hemisphere, no one would confuse one of these Gondwanan floral assemblages with one from Germany or from the Chinle Formation. It is expected that some of the problems associated with conchostracan biogeography will also sort themselves out as a consequence of this provinciality.

\section{There are no definitive Triassic ornithischian dinosaurs}

A major impediment to understanding the larger context of dinosaurian evolution is the ability to independently determine the relative ages of dinosaur-bearing strata. There are very few places where this is better seen than in the Molteno, Elliot and Clarens formations of the Karoo basin of southern Africa (Fig. 17). The latter two formations have yielded some of the best-preserved tetrapod assemblages of the early part of the early Mesozoic, including the best-preserved and most diverse assemblages of early ornithischian dinosaurs in the world, along with abundant sauropodomorphs.

The oldest unquestionable occurrence of ornithischians, Eocursor parvus (Butler et al. 2008), is from the lower Elliot Formation in the southern African section. Although not independently dated, this strata is purportedly of Late Triassic age, based on the specimen coming from $5.5 \mathrm{~m}$ below a nodular horizon conventionally used as a regional marker of the Triassic-Jurassic boundary (Smith \& Kitching 1997). This is a lithostratigraphic marker and has no geochronological support for its assumed age. Tetrapod assemblages (e.g. 'Tritylodon Acme Zone'; Kitching \& Raath 1984) that are conventionally identified as Jurassic aspect (Olsen \& Galton 1977, 1984) that lack taxa of Triassic aspect occur above this marker bed. Eocursor occurs $10.5 \mathrm{~m}$ above an articulated skull and skeleton of Melanosaurus readi (Yates 2005, 2007; Butler et al. 2007), a taxon considered to be Triassic in age (Knoll 2004).

A major problem with correlation of the Elliot and Clarens formations with marine standard ages is a lack of shared taxa, not just between the marine Tethyan sections and the southern African continental sections, but also with continental strata elsewhere that are dated with reasonable confidence. In fact, there is no justification from a biochronological or geochronological perspective for placing the Triassic-Jurassic boundary at a nodule horizon within the Elliot Formation. Indeed, correlation with the Triassic is based largely on the level of evolution within the sauropodomorphs, amphibians, the presence of a traversodont cynodont (Knoll 2004), and the Triassic aspect of the ichnofauna (Olsen \& Galton 1977, 1984; Knoll 2004). Knoll (2004) considers the age of the lower Elliot and underlying Molteno formations to be Norian-Rhaetian, but the Molteno Formation could easily be Carnian age. However, even if Melanosaurus is restricted to the Triassic, Eocursor is $10.5 \mathrm{~m}$ above this last Triassic-age fossil. The meaning of this thickness can be assessed by considering a plausible average accumulation rate for the Elliot and Clarens in the vicinity of the Eocursor locality. The lower Elliot Formation is $\sim 55 \mathrm{~m}$ thick (Smith \& Kitching 1997) and the middle plus upper Elliot Formation is $\sim 85 \mathrm{~m}$ thick (Butler et al. 2007). The overlying Clarens Formation is estimated at more than $\sim 130 \mathrm{~m}$ thick (Kitching \& Raath 1984). Using $150 \mathrm{~m}$ for an estimate of the Clarens Formation and 55+85 $\mathrm{m}$ for the Elliot Formation, the total thickness is $\sim 290 \mathrm{~m}$. The only tolerably reliable geochronological information constraining the age of the Clarens Formation is from the Drakensburg (Karoo) Lavas and associated pyroclastics that overlie and in part interfinger with it, yielding ${ }^{40} \mathrm{Ar} /{ }^{39} \mathrm{Ar}$ dates clustering at $183 \pm 2 \mathrm{Ma}$ (Pálfy \& 
Smith 2000) and U-Pb dates ranging from $182 \cdot 1 \pm 2 \cdot 9 \mathrm{Ma}$ to $179 \cdot 9 \pm 1 \cdot 8 \mathrm{Ma}$ (Riley et al. 2004). These dates correspond to the Toarcian of the late Early Jurassic (Pálfy \& Smith 2000) and show that the Elliot, together with the Clarens, may span as much as $\sim 44 \mathrm{Myr}$ (26 Myr for Norian-Rhaetian+18 Myr for the base Hettangian to the age of the Drakensburg Lavas). Thus the average accumulation rate is $6.5 \mathrm{~m} / \mathrm{Myr}$. Given this very slow accumulation rate, the interval between Eocursor and the youngest Triassic-aspect vertebrate (Melanorosaurus) would be 1.62 Myr, and from Eocursor to the Tritylodon Acme Zone is $\sim 2.54 \mathrm{Myr}$. Thus, within the biostratigraphic constraints, which themselves are of unclear significance, the uncertainty in age is $\sim 4.16 \mathrm{Myr}$. For comparison, the Hettangian spans $\sim 1.8 \mathrm{Myr}$ (Ruhl et al. 2010). Without independent geochronological data, it is not possible to determine the Triassic vs. Jurassic age of Eocursor. It could be Triassic, but it could be as young as Sinemurian in age.

Two other putative Triassic ornithischians include Pisanosaurus from the Ischigualasto Formation and a putative heterodontosaurid from the Laguna Colorada Formation of Patagonia (Baez \& Marsicano 2001) (Fig. 17). Irmis et al. (2007a) have recently reviewed the status of these two forms. They regard Pisanosaurus as plausibly belonging to the Ornithischia, however they note that the possibility of it not being an ornithischian has not been rigorously explored. While the characters visible on the fragmentary Laguna Colorada maxilla are consistent with a heterdontosaurid ornithischian, it is so fragmentary and there is so much apparent convergence among non-dinosaurian archosaurs with ornithischians that its relationships are in doubt pending more complete material. In addition, the age of the Laguna Colorada Formation itself is poorly constrained (age-relevant information in Pol \& Powell 2007). There are floral remains belonging to the Dicroidium flora, conventionally considered Triassic over- and underlying the tetrapod-bearing levels (Jalfin \& Herbst 1995; Gnaedinger \& Herbst 1998), and the sedimentary strata are intruded by La Leona Formation granitoids, yielding an $\mathrm{Rb}-\mathrm{Sr}$ isochron age of $203 \pm 2$ (Pankhurst et al. 1993) that is permissive of a Late Triassic age. However, the time of extinction of the Dicroidium floras is itself very poorly constrained and the $\mathrm{Rb}-\mathrm{Sr}$ age is within error of the Early Jurassic and may itself not be accurate, given the younger range of ages from other related intrusions (Varela et al. 1991; Pankhurst et al. 1993). Other examples of fragmentary possible ornithischians of Triassic age are probably referable to other groups (Irmis et al. 2007a). It can be concluded that the hypothesis that there are no Triassic ornithischians has yet to be definitively disproved by unambiguous material.

Saurischian diversity and abundance appears to have been increasing through the Late Triassic, with sauropodomorphs becoming very abundant in the higher latitudes (Fig. 17), which stands in dramatic contrast to the lack of definitive ornithischian remains from definitive Triassic age strata. Convincing ornithischian footprints in the form of the ichnogenus Anomoepus are restricted to Jurassic age strata (Olsen \& Rainforth 2003), including in the Newark and Hartford basin strata that form the basis for the Newark-APTS 2010. If, however, heterodontosaurids are basal ornithischians (e.g. Butler et al. 2008) their footprints might go unrecognised as such because they lack the manual specialisations seen in Anomoepus (Olsen \& Rainforth 2003). It is necessary to stress, however, that while the present authors vigorously assert that unequivocal ornithischians have yet to be documented in Triassic age strata, they acknowledge that available anatomical data from these scrappy specimens is permissive of inclusion within the Ornithischia and, based on ghost lineages (i.e., presence of fossils of their closest sister group, Saurischia) their presence should be predicted in the Late Triassic strata. However, given the fragmentary nature of these fossils and the problems with identifying Triassic ornithischians in the past, it would not be a surprise if they turned out to belong to a different and possibly non-dinosaurian clade. Regardless, at best, Triassic-age ornithischians are extraordinarily rare, and the dramatic change into the Jurassic in the abundance of osteological and ichnological specimens represents a significant ecological, if not evolutionary, event.

\section{The Rhaetian tetrapod record is poor}

The Rhaetian tetrapod record has long been regarded as poorly known (e.g., Ezcurra \& Cuny 2007). This deficit becomes all the more apparent when trying to seriate known assemblages globally on the basis of biostratigraphically independent criteria. However, amongst assemblages with abundant osteological remains, the correlations of Kozur \& Bachmann (2008) would have at least the younger components of the classic Germanic basin, such as the upper Stubensandstein (upper Löwenstein Formation) and Knollenmergel (Trossingen Formation), as being Rhaetian. Even a larger part of the Germanic basin section would be Rhaetian by including Sevatian 2, but biostratigraphically independent data are lacking. The Fleming Fjord Formation is Rhaetian based on correlation to the Newark-APTS 2010 time scale and to the Steinbergkogel section by magnetostratigraphy (Kent \& Clemmensen 1996; Hüsing et al. 2011). The Los Colorados Formation is likely at least in part Rhaetian, as is the upper Petrified Forest and Owl Rock members, although again these correlations require more rigorous independent confirmation. However, osteological faunas from the demonstrably youngest Rhaetian strata are still very poorly known, and this hampers our understanding of the Triassic-Jurassic transition (e.g. Tanner et al. 2004; Lucas \& Tanner 2007; Ezcurra \& Cuny 2007).

It is clear that there is much to be learned about Rhaetian assemblages. If the apparent Rhaetian age of the new assemblages from Poland (Dzik et al. 2008a) and Portugal (Witzmann \& Gassner 2008) are corroborated, many taxa, such as dicynodonts (e.g. Dzik et al. 2008a, b) thought to have had their last appearances much earlier, may have persisted through the entire Triassic. Such range extensions amplify our perception of the magnitude of the end-Triassic extinction event. They come from areas in which there were no formerly Rhaetian forms at all and may represent entirely new faunal entities.

\section{Diversity is high in the Late Triassic}

At least four basic kinds of diversity can be identified: taxonomic richness, relative taxonomic abundance, morphological disparity and biogeographic occurrence. The most common way diversity has been tabulated through time is via taxonomic diversity-various metrics of tabulations of the standing number, and first and last appearances. This is almost always what is referred to in discussions of mass-extinctions. For the Late Triassic, taxonomic richness is clearly climbing rapidly, as assemblages are sorted out with more rigour than before with strange and wonderful animals to be found (e.g. Effigia, Nesbitt 2007; Vancleavea, Nesbitt et al. 2009a). However, ecosystems can be dominated by just one or a few abundant forms, and most of the taxonomic diversity can consist of rare species. In the fossil record this is usually indistinguishable from low species richness, because the sample size is almost never large enough to capture many rare forms. Rarefaction 
analysis, rarely done, is necessary to allow comparison of relative abundance of taxa. Although relative abundances have not been quantified through time in any region, it appears that qualitatively, taxonomic relative abundances are stable or becoming more equable through the Late Triassic. Morphological disparity, how different things are from one another (e.g. Erwin 2007), is an additional important aspect of diversity, especially ecologically. Brusatte et al. (2008) have shown that disparity was relatively high in the Late Triassic, and increasing through the period, when overall fossil abundance is accounted for. We have commented on the high biogeographic provinciality of the Late Triassic, present despite the contiguity of the Pangean plate configuration. In all ways, diversity in the Late Triassic appears to have been high, but further advances require adherence to the search for tight independent temporal constraints allowing correlation and seriation among assemblages.

Although yet to be tested quantitatively, the overall pattern of high diversity in the late Triassic in all four senses listed above stands in dramatic contrast to the lower diversity seen in Early Jurassic age assemblages. The end-Triassic extinction event appears to have affected all aspects of diversity, and at least for higher-level taxonomic categories or in terms of gross morphological disparity, the recovery appears to have been slow (Brusatte et al. 2008). However, although the problems with Late Triassic global correlations have been detailed, and some solutions suggested, largely coming out of the NewarkAPTS (which extends only a few million years into the Jurassic) and new radioisotopic ages, the situation for the continental Early Jurassic is much worse. Stage-level correlations are largely not possible for most diverse Early Jurassic assemblages such as the lower Lufeng Formation of China or the Kayenta Formation of the American Southwest. Seriating and dating these assemblages will require considerable effort.

\section{Concluding remarks}

Construction of biostratigraphically independent methodologies for seriation, correlation and numerical calibration of important palaeobiological assemblages globally, including the development and refinement of the Newark-APTS as described here, is essential for understanding the tempo and mode of the rise of the dinosaurs. Although considerable effort has been made to show that dinosaur-bearing continental deposits are plausibly entirely Norian or younger in age, correlations to the Carnian or Norian are not regarded as intrinsically important for the origin and early history of dinosaurs. Correlation to these Tethyan marine constructs has become standard in discussions of early Mesozoic continental faunal change to a degree that far surpasses the actual usefulness of the concepts, and has often obscured or even hindered our understanding of temporal and geographic distributions. Indeed, in some ways, the names of the intervals have tended to become more important than the course of events. It is suggested that the focus should instead be on the pattern of biotic change through long sequences within single sedimentary basins, and how those changes can be relatively seriated with other changes globally to reveal biogeographic patterns, and then numerically calibrated to determine quantitative rates of change and correlation to physical events such as bolide impacts or large igneous provinces.

Magnetostratigraphic and radioisotopic correlation to the Newark-APTS 2010 demonstrates that the relative numerical timing of key time-stratigraphic intervals (sensu Hedberg 1948), such as the Tethyan marine standard stages and their presumed continental correlates, have often been grossly mis- interpreted, conflating interesting and important biogeographic patterns with temporal sequencing. In particular, the Rhaetian and Norian stages are much longer than generally assumed and the Carnian is correspondingly shorter. Based on correlation to the Newark-APTS 2010, it is concluded that the present record of dinosaurian diversification appears to be post-Carnian in age; that saurischian diversity and abundance was increasing slowly through the $\sim 26$ million year-long Norian plus Rhaetian interval; that the convincing record of ornithischian diversification is only post-Triassic in age; and that tetrapod diversity in all its meanings increased during the Triassic, with perhaps an abrupt though modest turnover associated with the Manicouagan impact (215.5 Ma, Ramezani et al, 2005), only to be cut back dramatically at the end-Triassic extinction event, itself closely correlated to the time of eruption of the CAMP. Only after the end-Triassic extinction event did dinosaurs become ecologically dominant globally.

\section{Acknowledgements}

Our thanks to Bruce Cornet who processed the new post-fern spike samples from Exeter and to Martijn Deenen, Philip Huber, Heinz Kozur, Randall Irmis, Jeff Martz, Sterling Nesbitt and William Parker for enlightening discussions. We acknowledge support from the US National Science Foundation (grants EAR 0753496 to PEO and DKV and EAR 0801138 to JHW). Comments from the editor, and from reviewers William Parker, Fernando Novas and Martín Ezcurra, were very helpful in improving the manuscript. We are also grateful to Max Langer, Randall Irmis and Richard Butler for inviting us to present at the 2009 Triassic Symposium at the Bristol, UK 2009 Meeting of the Society of Vertebrate Paleontology, an outcome of which is this paper. This is Lamont-Doherty Earth Observatory contribution 7465.

\section{References}

Arcucci, A. B., Marsicano, C. A., \& Caselli, A. T. 2004. Tetrapod association and palaeoenvironment of the Los Colorados Formation (Argentina): a significant sample from Western Gondwana at the end of the Triassic. Geobios 37, 557-68.

Artabe A. E., Morel E. M. \& Spalletti L. A. 2003. Caracterización de las provincias fitogeográficas triásicas de Gondwana extratropical. Ameghiniana 40, 387-405.

Ash, S. R. 1980. Upper Triassic floral zones of North America. In Dilcher, D. L. \& Taylor, T. N. (eds) Biostratigraphy of fossil plants, 153-70. Stroudsburg, Pennsylvania: Dowden, Hutchinson and Ross.

Ash, S. R. 1987. The Upper Triassic red bed flora of the Colorado Plateau, western United States. Journal of the Arizona-Nevada Academy of Science 22, 95-105.

Aubry, M.-P., Van Couvering, J. A., Christie-Blick, N. C., Landing, E., Pratt, B. R., Owen, D. E. \& Ferrusquía-Villafranca, I. 2009. Terminology of geological time: Establishment of a community standard. Stratigraphy 6, 100-05.

Baez, A. M. \& Marsicano, C. A. 2001. A heterodontosaur ornithischian dinosaur from the Upper Triassic of Patagonia. Ameghiniana 38, 271-79.

Beerling, D. J. \& Berner, R. A. 2002. Biogeochemical constraints on the Triassic-Jurassic boundary carbon cycle event. Global Biogeochemical Cycles 16 (3), 101-13.

Berg, H. C. 1973. Geology of Gravina Island, Alaska. United States Geological Survey Bulletin B1373, 1-41.

Berg, H. C. \& Cruze, L. 1982. Map and table describing fossil collections and related samples in the Ketchikan and Prince Rupert quadrangles, southeastern Alaska. United States Geological Survey, Open-File Report OF82-1088, 1-27.

Berger, A. 1977. Support for the astronomical theory of climate change. Nature 269, 44-45.

Berger, A. \& Loutre, M.-F. 1990. Origine de fréquences des éléments astronomiques intervenant dans le calcul de l'insolation. Bulletin 
de la Classe des Sciences, Académie Royale de Belgique 1-3, 45-106.

Blackburn, T., Bowring, S., Olsen, P., Kent, D., Rasbury, T. \& McHone, G. 2009. U-Pb zircon dating of Central Atlantic Magmatic Province: Implication for the Triassic-Jurassic extinction and the astrochronological timescale. Geological Society of America Abstracts with Programs 41 (7), 421.

Bonaparte, J. F. 1966. Chronological survey of the tetrapod-bearing Triassic of Argentina. Breviora 251, 1-13.

Bonaparte, J. F. 1982. Faunal replacement in the Triassic of South America. Journal of Vertebrate Paleontology 2, 362-71.

Brack, P., Mundil, R., Oberli, F., Meier, M. \& Rieber, H. 1997. Biostratigraphic and radiometric age data question the Milankovitch characteristics of the Latemar cycles (Southern Alps, Italy): reply. Geology 25, 471-72.

Brack, P., Rieber, H., Nicora, A. \& Mundil, R. 2005. The Global boundary Stratotype Section and Point (GSSP) of the Ladinian Stage (Middle Triassic) at Bagolino (Southern Alps, Northern Italy) and its implications for the Triassic time scale. Episodes $\mathbf{2 8}$ (4), $233-44$.

Brendonck, L., Rogers, D. C., Olesen, J., Weeks, S. \& Hoeh, W. R. 2008. Global diversity of large branchiopods (Crustacea: Branchiopoda) in freshwater. Hydrobiologia 595, 167-76.

Brusatte, S. L., Benton, M. J., Ruta, M. \& Lloyd, G. T. 2008. Superiority, competition, and opportunism in the evolutionary radiation of dinosaurs. Science 321, 1486-88.

Brusatte, S. L., Nesbitt, S. J., Irmis, R. B., Butler, R. J., Benton, M. J. \& Norell, M. A. 2010. The origin and early radiation of dinosaurs. Earth-Science Reviews 101, 68-100.

Buratti, N. \& Cirilli, S. 2007. Microfloristic provincialism in the Upper Triassic Circum-Mediterranean area and palaeogeographic implication. Geobios 40, 133-42.

Butler, R. J., Smith, R. M. H. \& Norman, D. B. 2007. A primitive ornithischian dinosaur from the Late Triassic of South Africa, and the early evolution and diversification of Ornithischia. Proceedings of the Royal Society B 274, 2041-46.

Butler, R. J., Upchurch, P. \& Norman, D. B. 2008. The phylogeny of the ornithischian dinosaurs. Journal of Systematic Palaeontology 6 (1), 1-40.

Chang, W., Chen, P. \& Shen Y. 1976. Fossil Conchostraca of China. Beijing: Science Press. 325 pp.

Channell, J. E. T., Kozur, H. W., Sievers, T., Mock, R., Aubrecht, R. \& Sykora, M. 2003. Carnian-Norian bio-magnetostratigraphy at Silicka Brezova (Slovakia): Correlation to other Tethyan sections and to the Newark Basin. Paleogeography, Palaeoclimatology, Palaeoecology 191, 65-109.

Cirilli, S., Marzoli, A., Tanner, L., Bertrand, H., Buratti, N., Jourdan, F., Bellieni, G., Kontak, D. \& Renne, P. R. 2009. Latest Triassic onset of the Central Atlantic Magmatic Province (CAMP) volcanism in the Fundy Basin (Nova Scotia): New stratigraphic constraints. Earth and Planetary Science Letters 286 (3-4), 514-25.

Cleveland, D. M., Atchley, S. C. \& Nordt, L. C. 2007. Continental sequence stratigraphy of the Upper Triassic (Norian-Rhaetian) Chinle strata, northern New Mexico, U.S.A.: allocyclic and autocyclic origins of paleosol-bearing alluvial successions. Journal of Sedimentary Research 77, 909-24.

Cleveland, D. M., Nordt, L. C., Sworkin, S. I. \& Atchley, S. C. 2008. Pedogenic carbonate isotopes as evidence for extreme climatic events preceding the Triassic-Jurassic boundary: implications for the biotic crisis? Geological Society of America Bulletin 120(11/12), 1408-15.

Cornet, B. 1977. The Palynostratigraphy and Age of the Newark Supergroup. PhD Thesis, The Pennsylvania State University, University Park. 527 pp.

Cornet, B. 1993. Applications and limitations of palynology in age, climatic, and paleoenvironmental analyses of Triassic sequences in North America. In Lucas, S. G. \& Morales, M. (eds) The non-marine Triassic. New Mexico Museum of Natural History and Science Bulletin 3, 75-93. Albuquerque: New Mexico Museum of Natural History and Science.

Cornet, B. \& Olsen, P. E. 1985. A summary of the biostratigraphy of the Newark Supergroup of eastern North America with comments on Early Mesozoic provinciality, In Weber R. (ed.) Symposio Sobre Flores del Triasico Tardio st Fitografia y Paleoecologia, Memoria. Proc. II Latin-American Congress on Paleontology (1984), 67-81. Mexico City: Instituto de Geologia Universidad Nacional Autonoma de Mexico.

Cornet, B. \& Traverse, A. 1973. Fossil spores, pollen and fishes from Connecticut indicate Early Jurassic age for part of the Newark Group. Science 182, 1243-47.
Courtillot, V., Jaeger, J. J., Yang, Z., Féraud, G. \& Hoffmann, C. 1996. The influence of continental flood basalts on mass extinctions: where do we stand? Geological Society of America Special Paper 307, 513-25. Boulder, Colorado and Lawrence, Kansas: Geological Society of America and University of Kansas Press.

Currie, B. S., Colombi, C. E., Tabor, N. J., Shipman, T. C. \& Montañez, I. P. 2009. Stratigraphy and architecture of the Upper Triassic Ischigualasto Formation, Ischigualasto Provincial Park San Juan, Argentina. Journal of South American Earth Sciences 27, 74-87.

Deenen, M. H. L., Ruhl, M., Bonis, N. R., Krijgsman, W. Kuerschner, W. M., Reitsma, M. \& Van Bergen, M. J. 2010. A new chronology for the end-Triassic mass extinction. Earth and Planetary Science Letters 291, 113-25.

Deenen, M. H. L., Krijgsman, W. \& Ruhl, M. 2011. The quest for chron E23r at Partridge Island, Bay of Fundy, Canada: CAMP emplacement post-dates the end-Triassic extinction event at the North American craton. Canadian Journal of Earth Sciences. In press.

Dickinson, W. R. \& Gehrels, G. E. 2009. Use of U-Pb ages of detrital zircons to infer maximum depositional ages of strata: A test against a Colorado Plateau Mesozoic database. Earth and Planetary Science Letters 288 (1-2), 115-25.

Dobruskina, I. 1993. Relationship in floral and faunal evolution during the transition from the Paleozoic to the Mesozoic. In Lucas, S. G. \& Morales, M. (eds) The non-marine Triassic. New Mexico Museum of Natural History and Science Bulletin 3,113-16. Albuqueque: New Mexico Museum of Natural History and Science.

Dolby, J. H. \& Balme, B. E. 1976. Triassic palynology of the Carnarvon Basin, Western Australia. Review of Palaeobotany and Palynology 22, 105-68.

Dunlavey, M. G., Whiteside, J. H. \& Irmis, R. B. 2009. Ecosystem instability during the rise of dinosaurs: evidence from the Late Triassic in New Mexico and Arizona. Geological Society of America Abstracts with Programs 41, 477.

Dunning, G. R. \& Hodych, J. P. 1990. U/Pb zircon and baddeleyite ages for the Palisades and Gettysburg sills of the northeastern United States: Implications for the age of the Triassic/Jurassic boundary. Geology 18, 795-98.

Dzik, J., Sulej, T. \& Niedzwiedzki, G. 2008a. A dicynodont-theropod association in the latest Triassic of Poland. Acta Palaeontologica Polonica 53 (4), 733-38.

Dzik, J., Niedzwiedzki, G. \& Sulej, T. 2008b. Zaskakujące uwieńczenie ery gadów Ssakokształtnych. Ewolucja 3, 2-42.

Erwin, D. H. 2007. Disparity: morphological pattern and developmental context. Palaeontology 50, 57-73.

Ezcurra, M. D. 2010. Biogeographic analysis of Triassic tetrapods: evidence for biotic provincialism and driven sympatric cladogenesis in the early evolution of modern tetrapod lineages. Proceedings of the Royal Society Series B 277, 2547-52.

Ezcurra, M. D. \& Cuny, G. 2007. The coelophysoid Lophostropheus airelensis nov. gen.: a review of the systematics of 'Liliensternus' airelensis from the Triassic-Jurassic outcrops of Normandy (France). Journal of Vertebrate Paleontology 27, 73-86.

Fedosh, M. S. \& Smoot, J. P. 1988. A cored stratigraphic section through the northern Newark basin, New Jersey. U.S. Geological Survey Circular 946, 19-24.

Fowell, S. J. 1994. Palynology of Triassic/Jurassic Boundary Sections from the Newark Supergroup of Eastern North America: Implications for Catastrophic Extinction Scenarios. PhD Thesis, Columbia University, New York, Department of Earth and Environmental Sciences. 154 pp.

Fowell, S. J., Cornet, B. \& Olsen, P. E. 1994. Geologically rapid Late Triassic extinctions: Palynological evidence from the Newark Supergroup. Geological Society of America, Special Paper 288, 197-206. Boulder, Colorado and Lawrence, Kansas: Geological Society of America and University of Kansas Press.

Fowell, S. J. \& Olsen, P. E. 1993. Time calibration of Triassic/Jurassic microfloral turnover, eastern North America. Tectonophysics 222, 361-69.

Fowell, S. J. \& Traverse, A. 1995. Palynology and age of the upper Blomidon Formation, Fundy basin, Nova Scotia. Review of Palaeobotany and Palynology 86, 211-33.

Friedman, R., Mundil, R. \& Pálfy, J. 2008. Revised zircon U-Pb ages for the Triassic-Jurassic boundary and the earliest Jurassic employing the chemical abrasion pretreatment (CA-TIMS) technique. Geochimica et Cosmochimica Acta 72 (12), A284.

Furin, S., Preto, N., Rigo, M., Roghi, G., Gianolla, P., Crowley, J. L. \& Bowring, S. A. 2006. High-precision U-Pb zircon age from the Triassic of Italy: Implications for the Triassic time scale and 
the Carnian origin of calcareous nannoplankton and dinosaurs. Geology 34 (12), 1009-12.

Furrer, H., Schaltegger, U., Ovtcharova, M. \& Meister, P. 2008. U-Pb zircon age of volcaniclastic layers in Middle Triassic platform carbonates of the Austroalpine Silvretta nappe (Switzerland). Swiss Journal of Geosciences 101, 595-603.

Gallet, Y., Besse, J., Krystyn, L., Marcoux, J. \& Theveniaut, H. 1992. Magnetostratigraphy of the late Triassic Boltucektasi Tepe section (southwestern Turkey): implications for changes in magnetic reversal frequency. Physics of the Earth and Planetary Interiors 73, 85-108.

Gallet, Y., Besse, J., Krystyn, L., Theveniaut, H. \& Marcoux, J. 1993. Magnetostratigraphy of the Kavur Tepe section (southwestern Turkey): A magnetic polarity time scale for the Norian. Earth and Planetary Science Letters 117 (3-4), 443-56.

Gallet, Y., Besse, J., Krystyn, L., Marcoux, J., Guex, J. \& Theveniaut, H. 2000. Magnetostratigraphy of the Kavaalani section (southwestern Turkey): Consequence for the origin of the Antalya Calcareous Nappes (Turkey) and for the Norian (Late Triassic) magnetic polarity timescale. Geophysical Research Letters 27, 2033-36.

Gallet, Y., Krystyn, L., Besse, J. \& Marcoux, J. 2003. Improving the Upper Triassic numerical time scale from cross-correlation between Tethyan marine sections and the continental Newark Basin sequence. Earth and Planetary Science Letters 212, 255-61.

Gallet, Y., Krystyn, L., Besse, J. \& Marcoux, J. 2007. New constraints on the End-Triassic (Upper Norian-Rhaetian) magnetostratigraphy. Earth and Planetary Science Letters 255, 458-70.

Gatesy, S. M., Middleton, K. M., Jenkins, F. A. J., Jr \& Shubin, N. H. 1999. Three-dimensional preservation of foot movements in Triassic theropod dinosaurs. Nature 399, 141-44.

Gehrels, G. E., Saleeby, J. B. \& Berg, H. C. 1987. Geology of Annette, Gravina, and Duke islands, southeastern Alaska. Canadian Journal of Earth Science 24, 866-81.

Gehrels, G. E. \& Dickinson, W. R. 1995. Detrital zircon provenance of Cambrian to Triassic miogeoclinal and eugeoclinal strata in Nevada. American Journal of Science 295, 18-48.

Gnaedinger, S. \& Herbst, R. 1998. La flora triásica del Grupo El Tranquilo, provincia de Santa Cruz (Patagonia). Parte IV. Pteridospermae. Ameghiniana 35, 33-52.

Gradstein, F. M., Agterberg, F. P., Ogg, J. G., Hardenbol, J., van Veen, P., Thierry, J. \& Huang, Z. 1994. A Mesozoic time scale. Journal of Geophysical Research 99, 24051-74.

Gradstein, F. M., Ogg, J. G. \& Smith, A. G. (eds) 2005. A Geologic Time Scale 2004. Cambridge, UK: Cambridge University Press.

Gradstein, F. M. \& Ogg, J. 1996. A Phanerozoic time scale. Episodes $19,3-5$.

Hallam, A. 2002. How catastrophic was the end-Triassic mass extinction? Lethaia 35, 147-57.

Harland, W. B., Armstrong, R. L., Cox, A. V., Craig, L. E., Smith, A. G. \& Smith, D. G. 1990. A Geologic Time Scale (1989 edn). Cambridge, UK: Cambridge University Press. 263 pp.

Heckert, A. B. \& Lucas, S. G. 2002a. South American occurrences of the Adamanian (Late Triassic: Latest Carnian) index taxon Stagonolepis (Archosauria:Aetosauria) and their biochronological significance. Journal of Paleontology 76, 852-63.

Heckert, A. B. \& Lucas, S. G. 2006. Micro- and small vertebrate biostratigraphy and biochronology of the Upper Triassic Chinle Group, southwestern USA. In Harris, J. D., Lucas, S. G., Spielmann, J. A., Lockley, M. G., Milner, Andrew, C. \& Kirkland, J. I. (eds) The Triassic-Jurassic Terrestrial Transition. New Mexico Museum of Natural History and Science Bulletin $\mathbf{3 7}$, 94-104.

Heckert, A. B., Lucas, S. G., Dickinson, W. R. \& Mortensen, J. K. 2009. New ID-TIMS U-Pb ages for Chinle Group strata (Upper Triassic) in New Mexico and correlation to the Newark Supergroup and implications for the 'long Norian'. Geological Society of America, Abstracts with Programs 41 (7), 123.

Hedberg, H. 1948. Time-stratigraphic classification of sedimentary rocks. Geological Society of America Bulletin 59 (5), 447-62.

Hesselbo, S. P., Robinson, S. A., Surlyk, F. \& Piasecki, S. 2002. Terrestrial and marine extinction at the Triassic-Jurassic boundary synchronized with major carbon-cycle perturbation: A link to initiation of massive volcanism? Geology 30 (3), 251-54.

Hillebrandt, A. V., Krystyn, L. \& Kuerchner, W. M. 2007. A candidate GSSP for the base of the Jurassic in the Northern Calcareous Alps (Kuhjoch section, Karwendel Mountains, Tyrol, Austria). International Subcommission on Jurassic Stratigraphy, Newsletter 34 (1), 2-20.

Hillebrandt, A. V. \& Krystyn, L. 2009. On the oldest Jurassic ammonites of Europe (Northern Calcareous Alps, Austria) and their global significance. Neues Jahrbuch für Geologie und Paläontologie, Abhandlungen 253, 163-95.

Hochuli, P. A., Colin, J. P. \& Vigran, J. O. 1989. Triassic biostratigraphy of the Barents Sea area. In Collinson, J. D. (ed.) Correlation in Hydrocarbon Exploration, 131-53. London: Norwegian Petroleum Society, Graham \& Trotman.

Hochuli, P. A. \& Vigran, J. O. 2010. Climate variations in the Boreal Triassic - Inferred from palynological records from the Barents Sea. Palaeogeography, Palaeoclimatology, Palaeoecology 290, $20-42$.

Holtz, T. R., Champan, R. E. \& Lamanna, M. C. 2004. Mesozoic biogeography of dinosaurs. In Weishampel, D., Dodson, P. \& Osmólska, H. (eds) The Dinosauria (2nd edn), 627-42. Berkeley: University of California Press.

Hounslow, M. W., Posen, P. E. \& Warrington, G. 2004. Magnetostratigraphy and biostratigraphy of the Upper Triassic and lowermost Jurassic succession, St. Audrie's Bay, UK. Palaeogeography, Palaeoclimatology, Palaeoecology 213 (3-4), 331-58.

Huber, P., Lucas, S. G. \& Hunt, A. P. 1993. Vertebrate biochronology of the Newark Supergroup Triassic, eastern North America. In Lucas, S. G. \& Morales, M. (eds) The non-marine Triassic. New Mexico Museum of Natural History and Science Bulletin 3, 179-86. Albuquerque: New Mexico Museum of Natural History and Science.

Hunt, A. P., Lucas, S. G. \& Heckert, A. B. 2005. Definition and correlation of the Lamyan: a new biochronological unit for the nonmarine late Carnian (Late Triassic). New Mexico Geological Society Guidebook 56, 357-66.

Hüsing, S. K., Deenen, M. H. L., Koopmans, J. \& Krijgsman, W. 2011. Magnetostratigraphic dating of the Rhaetian GSSP at Steinbergkogel (upper Triassic, Austria): implications for the Late Triassic Time Scale. Earth and Planetary Science Letters 302, 203-16.

Ilyina, N. V. \& Egorov, A. Y. 2008. The Upper Triassic of northern Middle Siberia : stratigraphy and palynology. Polar Research $\mathbf{2 7}$ (3), 372-92.

Irmis, R. B., Parker, W. G., Nesbitt, S. J. \& Liu, J. 2007a. Early ornithischian dinosaurs: the Triassic record. Historical Biology 19 (1), 3-22.

Irmis, R. B., Nesbitt, S. J., Padian, K., Smith, N. D., Turner, A. H., Woody, D. \& Downs, A. 2007b. A Late Triassic dinosauromorph assemblage from New Mexico and the rise of dinosaurs. Science 317, 358-61.

Irmis, R. B., Martz, J. W., Parker, W. G. \& Nesbitt, S. J. 2010. Re-evaluating the correlation between Late Triassic terrestrial vertebrate biostratigraphy and the GSSP-defined marine stages. Albertiana 38, 40-52.

Irmis, R. B. \& Mundil, R. 2008. New age constraints from the Chinle Formation revise global comparisons of Late Triassic vertebrate assemblages. Journal of Vertebrate Paleontology 28, 95A.

Irmis, R. B. \& Whiteside, J. H. 2010. Newly integrated approaches to studying Late Triassic Terrestrial Ecosystems. Palaios 25, 689-91.

Jalfin, G. A. \& Herbst, R. 1995. La flora triásica del grupo El Tranquilo, Provincia de Santa Cruz (Patagonia), estratigrafía. Ameghiniana 32, 211-29.

Jenkins, F. A., Jr, Shubin, N. H., Schaff, C. R., Amaral, W. W., Gatesy, S. M. \& Downs, W. R. 1993. A new record of Late Triassic mammals from the Fleming Fjord Formation, Jameson Land, East Greenland. In Lucas, S. G. \& Morales, M. (eds) The non-marine Triassic. New Mexico Museum of Natural History and Science Bulletin 3, 94. Albuquerque: New Mexico Museum of Natural History and Science.

Jenkins, F. A., Shubin, N. H., Amaral, W. W., Gatesy, S. M., Schaff, C. R., Clemrnensen, L. B., Downs, W. R., Davidson, A. R., Bonde, N. \& Osbaeck, F. 1994. Late Triassic continental vertebrates and depositional environments of the Fleming Fjord Formation, Jameson Land, East Greenland. Meddelelser om Gronland, Geo-science 32, 1-25.

Jenkins, F. A., Jr, Gatesy, S. M., Shubin, N. H. \& Amaral, W. M. 1997. Haramiyids and Triassic mammalian evolution. Nature 385, 715-18.

Jenkins, F. A., Jr, Shubin, N. H., Gatesy, S. M. \& Padian, K. 2001. A diminutive pterosaur (Pterosauria: Eudimorphodontidae) from the Greenlandic Triassic. Bulletin of the Museum of Comparative Zoology, Harvard 156 (1), 151-70.

Jenkins, F. A., Jr, Shubin, N. H., Gatesy, S. M. \& Warren, A. 2008. Gerrothorax pulcherrimus from the upper Triassic Fleming Fjord Formation of East Greenland and a reassessment of head lifting in temnospondyl feeding. Journal of Vertebrate Paleontology 28 (4), 935-50. 
Kent, D. V., Olsen, P. E. \& Witte, W. K. 1995. Late Triassic-Early Jurassic geomagnetic polarity and paleolatitudes from drill cores in the Newark rift basin (Eastern North America). Journal of Geophysical Research 100 (B8), 14,965-98.

Kent, D. V. \& Clemmensen, L. B. 1996. Paleomagnetism and cycle stratigraphy of the Triassic Fleming Fjord and Gipsdalen Formations of East Greenland. Bulletin of the Geological Society of Denmark 42, 121-36.

Kent, D. V. \& Olsen, P. E. 1999. Search for the Triassic/Jurassic long normal and the J1 cusp. Eos, Transactions, American Geophysical Union, Supplement 80 (46), F306.

Kent, D. V. \& Olsen, P. E. 2008. Early Jurassic magnetostratigraphy and paleolatitudes from the Hartford continental rift basin (eastern North America): Testing for polarity bias and abrupt polar wander in association with the central Atlantic magmatic province. Journal of Geophysical Research 113, B06105, doi:10.1029/ 2007JB005407.

Kent, D. V. \& Tauxe, L. 2005. Corrected Late Triassic latitudes for continents adjacent to the North Atlantic. Science 307, 240-44.

Kitching, J. W. \& Raath, M. A. 1984. Fossils from the Elliot and Clarens formations (Karoo Sequence) of the Northeastern Cape, Orange Free State and Lesotho, and a suggested biozonation based on tetrapods. Palaeontologica Africana 25, 111-25.

Knoll, F. 2004. Review of the tetrapod fauna of the 'Lower Stormberg Group' of the main Karoo Basin (southern Africa): implication for the age of the Lower Elliot Formation. Bulletin de la Société Géologique de France 175 (1), 73-83.

Kozur, H. W. \& Bachmann, G. H. 2008. Updated correlation of the Germanic Triassic with the Tethyan scale and assigned numeric ages. Berichte der Geologischen Bundesanstalt der ÖsterreichAbstracts 76, 53-56.

Kozur, H. W. \& Weems, R. E. 2005. Conchostracan evidence for a late Rhaetian to early Hettangian age for the CAMP volcanic event in the Newark Supergroup, and a Sevatian (late Norian) age for the immediately underlying beds. Hallesches Jahrbuch für Geowissenschaften B27, 21-51.

Kozur, H. W. \& Weems, R. E. 2007. Upper Triassic conchostracan biostratigraphy of the continental rift basins of eastern North America: its importance for correlating Newark Supergroup events with the Germanic Basin and the international geologic time scale. In Lucas, S. G. \& Spielmann, J. A. (eds) The Global Triassic. New Mexico Museum of Natural History and Science Bulletin 41, 137-88. Albuquerque: New Mexico Museum of Natural History and Science.

Kozur, H. W. \& Weems, R. E. 2008. Upper Triassic to lowermost Jurassic conchostracan zonation of the Newark Supergroup and its correlation with the marine scale: The CAMP volcanism straddles the Triassic-Jurassic boundary (TJB). Abstracts, 33rd IGC, Oslo. http://www.cprm.gov.br/33IGC/1321943.html.

Kozur, H. W. \& Weems, R. E. 2010. The biostratigraphic importance of conchostracans in the continental Triassic of the northern hemisphere. Geological Society, London, Special Publication 334, 315-417.

Krystyn, L., Bouquerel, H., Kürschner, W., Richoz, S. \& Gallet, Y. 2007a. Proposal for a candidate GSSP for the base of the Rhaetian Stage. In Lucas, S. G. \& Spielmann, J. A. (eds) The Global Triassic. New Mexico Museum of Natural History and Science Bulletin 41, 189-99. Albuquerque: New Mexico Museum of Natural History and Science.

Krystyn, L., Richoz, S., Gallet, Y., Bouquerel, H., Kürschner, W. M. \& Spötl, C. 2007b. Updated bio- and magnetostratigraphy from Steinbergkogel (Austria), candidate GSSP for the base of the Rhaetian stage. Albertiana 36, 164-73.

Kürschner, W. M., Bonis, N. R. \& Krystyn, L. 2007. Carbon-isotope stratigraphy and palynostratigraphy of the Triassic-Jurassic transition in the Tiefengraben section - Northern Calcareous Alps (Austria). Palaeogeography, Palaeoclimatology, Palaeoecology 244, 257-80.

Langer, M. C. 2005. Studies on continental Late Triassic tetrapod biochronology. II. The Ischigualastian and a Carnian global correlation. Journal of South American Earth Sciences 19, 219-39.

Langer, M. C., Ezcurra, M. D., Bittencourt, J. S. \& Novas, F. E. 2009. The origin and early evolution of dinosaurs. Biological Reviews 84, $1-56$.

Laskar, J. 1990. The chaotic motion of the solar system: a numerical estimate of the size of the chaotic zones. Icarus 88, 266-91.

Laskar, J., Robutel, P., Joutel, F., Gastineau, M., Correia, A. C. M. \& Levrard, B. 2004. A long-term numerical solution for the insolation quantities of the Earth. Astronomy and Astrophysics 428, $261-85$.
LeTourneau, P. M. 2003. Stratigraphic architecture and paleomagnetic reversal stratigraphy of the Late Triassic Taylorsville Basin, Virginia and Maryland. In LeTourneau, P. M. \& Olsen, P. E. (eds) The Great Rift Valleys of Pangea in Eastern North America, Volume 2, Sedimentology, Stratigraphy, and Paleontology, 12-18. New York: Columbia University Press.

Litwin, R. J, Traverse, A. \& Ash, S. R. 1991. Preliminary palynological zonation of the Chinle Formation, southwestern U.S.A., and its correlation to the Newark Supergroup (eastern USA). Review of Palaeobotany and Palynology 68, 269-87.

Litwin, R. J. \& Skog, J. E. 1991. Morphology and Palynostratigraphy of the Genus Camerosporites Leschik, 1956. Palynology 15, 5-28.

Lucas, S. G. 1990. Toward a vertebrate biochronology of the Triassic. Albertiana 8, 36-41.

Lucas, S. G. 1991. Sequence stratigraphic correlation of nonmarine and marine Late Triassic biochronologies, western United States. Albertiana 9, 11-18.

Lucas, S. G. 1993. The Chinle Group: Revised Stratigraphy and Biochronology of Upper Triassic Nonmarine Strata in the Western United States. In Morales, M (ed.) Aspects of Mesozoic Geology and Paleontology of the Colorado Plateau. Museum of Northern Arizona Bulletin 59, 27-50. Flagstaff: Museum of Northern Arizona Press.

Lucas, S. G. 1998. Global Triassic tetrapod biostratigraphy and biochronology. Palaeogeography, Palaeoclimatology, Palaeoecology $143,347-84$

Lucas, S. G. 2010. The Triassic timescale based on nonmarine tetrapod biostratigraphy and biochronology. Geological Society, London, Special Publication 334, 447-500.

Lucas, S. G., Heckert, A. B. \& Huber, P. 1998. Aetosaurus (Archosauromorpha) from the Upper Triassic of the Newark Supergroup, eastern United States, and its biochronological significance. Palaeontology 41, 1215-30.

Lucas, S. G., Hunt, A. P., Heckert, A. B. \& Spielmann, J. A. 2007. Global Triassic tetrapod biostratigraphy and biochronology: 2007 status. In Lucas, S. G. \& Spielmann, J. A. (eds) The Global Triassic. New Mexico Museum of Natural History and Science Bulletin 41, 229-40. Albuquerque: New Mexico Museum of Natural History and Science.

Lucas, S. G., Tanner, L. H., Donohoo-Hurley, L. L., Geissman, J. W., Kozur, H. W., Heckert, A. B. \& Weems, R. E. 2011. Position of the Triassic-Jurassic boundary and timing of the end-Triassic extinctions on land: Data from the Moenave Formation on the southern Colorado Plateau, USA. Palaeogeography, Palaeoclimatology, Palaeoecology 302, 194-205.

Lucas, S. G. \& Huber, P. 1993. Revised internal correlation of the Newark Supergroup Triassic, eastern States and Canada. In Lucas, S. G. \& Morales, M. (eds) The non-marine Triassic. New Mexico Museum of Natural History and Science Bulletin 3, 311-19. Albuquerque: New Mexico Museum of Natural History and Science.

Lucas, S. G. \& Huber, P. 1994. Sequence stratigraphic correlation of Upper Triassic marine nonmarine strata, western United States and Europe. Canadian Association of Petroleum Geologists Memoir 17, 241-54. Calgary, Alberta: Canadian Association of Petroleum Geologists.

Lucas, S. G. \& Huber, P. 2003. Vertebrate biostratigraphy and biochronology of the nonmarine Late Triassic. In LeTourneau, P. M. \& Olsen, P. E. (eds) The Great Rift Valleys of Pangea in Eastern North America, Volume 2: Sedimentology, Stratigraphy, and Paleontology, 143-91. New York: Columbia University Press.

Lucas, S. G. \& Hunt, A. P. 1993. Tetrapod biochronology of the Chinle Group (Upper Triassic), western United States. In Lucas, S. G. \& Morales, M. (eds) The non-marine Triassic. New Mexico Museum of Natural History and Science Bulletin 3, 327-29. Albuquerque: New Mexico Museum of Natural History and Science.

Lucas, S. G. \& Tanner, L. H. 2007. The nonmarine Triassic-Jurassic boundary in the Newark Supergroup of eastern North America. Earth-Science Reviews 84, 1-20.

Mander, L., Twitchett, R. J. \& Benton, M. J. 2008. Palaeoecology of the Late Triassic extinction event in the SW UK. Journal of the Geological Society, London 165, 319-32.

Martinez, R. N., Sereno, P. C., Alcober, O. A., Colombi, C. E., Renne, P. R., Montañez, I. P. \& Currie, B. S. 2011. A basal dinosaur from the dawn of the dinosaur era in southwestern Pangaea. Science 331, 206-10.

Martz, J. W. 2008. Lithostratigraphy, chemostratigraphy, and vertebrate biostratigraphy of the Dockum Group (Upper Triassic), of southern Garza County, West Texas. Unpublished PhD Dissertation. Texas Tech University, Lubbock. 504 pp. 
Martz, J. W. \& Parker, W. G. 2010. Revised lithostratigraphy of the Sonsela Member (Chinle Formation, Upper Triassic) in the southern part of Petrified Forest National Park, Arizona. PLoS ONE 5 (2): e9329. doi:10.1371/journal.pone.0009329.

Marzolf, J. E. 1993. Sequence-stratigraphic relationships across the palinspastically reconstructed Cordilleran Triassic cratonal margin. In Lucas, S. G. \& Morales, M. (eds) The nonmarine Triassic. New Mexico Museum of Natural History Bulletin 3, 331-43. Albuquerque: New Mexico Museum of Natural History and Science.

Marzoli, A., Renne, P. R., Piccirillo, E. M., Ernesto, M., Bellieni, G. \& De Min, A. 1999. Extensive 200-million-year-old continental flood basalts of the Central Atlantic magmatic province. Science 284, 616-18.

Marzoli, A., Bertrand, H., Knight, K. B., Cirilli, S., Buratti, N., Vérati, C., Nomade, S., Renne, P. R., Youbi, N., Martini, R., Allenbach, K., Neuwerth, R., Rapaille, C., Zaninetti, L. \& Bellieni, G. 2004. Synchrony of the Central Atlantic magmatic province and the Triassic-Jurassic boundary climatic and biotic crisis. Geology 32, 973-76.

Mayall, M. J. 1983. An earthquake origin for synsedimentary deformation in a late Triassic (Rhaetian) lagoonal sequence, southwest Britain. Geological Magazine 120, 613-22.

McCune, A. R. 1990. Evolutionary novelty and atavism in the Semionotus complex: relaxed selection during colonization of an expanding lake. Evolution 44 (1), 71-85.

McElwain, J. C., Beerling, D. J. \& Woodward, F. I. 1999. Fossil plants and global warming at the Triassic-Jurassic boundary. Science 285, 1386-90.

McElwain, J. C., Popa, M. E., Hesselbo, S. P., Haworth, M. \& Surlyk, F. 2007. Macroecological responses of terrestrial vegetation to climatic and atmospheric change across the Triassic/Jurassic boundary in East Greenland. Paleobiology 33 (4), 547-73.

Metcalfe, I. \& Isozaki, Y. 2009. Current perspectives on the PermianTriassic boundary and end-Permian mass extinction: Preface. Journal of Asian Earth Sciences 36 (6), 407-12.

Min, K., Mundil, R., Renne, P. R. \& Ludwig, K. R. 2000. A test for systematic errors in ${ }^{40} \mathrm{Ar} /{ }^{39} \mathrm{Ar}$ geochronology through comparison with $\mathrm{U} / \mathrm{Pb}$ analysis of a $1 \cdot 1-\mathrm{Ga}$ rhyolite. Geochimica et Cosmochimica Acta 64 (1), 73-98.

Mørk, A., Vigran, J. O., Korchinskaya, M. V., Pchelina, T. M., Fefilova, L. A., Vavilov, M. N. \& Weitschat, W. 1992. Triassic rocks in Svalbard, the Arctic Soviet islands and the Barents Shelf: Bearing on their correlations. In Vorren, T. O., Bergsager, E., Dahl-Stamnes, O. A., Holter, B., Johansen, B., Lie, E. \& Lund, T. B. (eds) Arctic geology and petroleum potential. Norwegian Petroleum Society, Special Publication 2, 457-79. Dordrecht, The Netherlands: Elsevier.

Morton, N. 2008a. Selection and voting procedures for the base Hettangian. International Subcommission on Jurassic Stratigraphy, Newsletter 35 (1), 67.

Morton, N. 2008b. Details of voting on proposed GSSP and ASSP for the base of the Hettangian Stage and Jurassic System. International Subcommission on Jurassic Stratigraphy, Newsletter 35 (1), 74.

Morton, N., Warrington, G. \& Bloos, G. 2008. Foreword. International Subcommission on Jurassic Stratigraphy, Newsletter 35 (1), 68-73.

Mojsisovics, E. v. 1869. Über die Gliederung der oberen Triasbildungen der östlichen Alpen. Geologische Reichsanstalt Jahrbuch 24, 91-150.

Mojsisovics, E. v. 1893. Das Gebirge um Halstatt II: Abhandlungen der Geologische Reichanstalt, Wien 6/II. $835 \mathrm{pp}$.

Mundil, R., Brack, P., Meier, M., Rieber, H. \& Oberli, F. 1996. High-resolution $\mathrm{U} / \mathrm{Pb}$ dating of Middle Triassic volcanoclastics: Time scale calibration and verification of tuning parameters for carbonate sedimentation. Earth and Planetary Science Letters 141, $137-51$.

Mundil, R. \& Irmis, R. 2008. New U-Pb age constraints for terrestrial sediments in the Late Triassic: Implications for faunal evolution and correlations with marine environments. 33rd IGC Meeting, Oslo, Abstract HPF-16.

Mundil, R., Renne, P. R., Min, K. K. \& Ludwig, K. R. 2006. Resolvable miscalibration of the ${ }^{40} \mathrm{Ar} /{ }^{39} \mathrm{Ar}$ geochronometer, Eos Transactions $A G U$, Fall Meeting Supplement V21A-0543.

Muttoni, G., Kent, D. V., Olsen, P. E., Di Stefano, P., Lowrie, W., Bernasconi, S. M. \& Hernandez, F. M. 2004. Tethyan magnetostratigraphy from Pizzo Mondello (Sicily) and correlation to the Late Triassic Newark astrochronological polarity time scale. Geological Society of America Bulletin 116 (9-10), 1043-58.
Muttoni, G., Kent, D. V., Jadoul, F., Olsen, P. E., Rigo, M., Galli, M. T. \& Nicora, A. 2010. Rhaetian magneto-biostratigraphy from the southern Alps (Italy): constraints on Triassic chronology. Palaeogeography, Palaeoclimatology, Palaeoecology 285 (1-2), $1-16$.

Naganawa, H. \& Zagas, B. 2002. General aspects of the large branchiopod crustacean fauna of Mongolia. Limnology 3, 181-88.

Nesbitt, S. 2007. The anatomy of Effigia okeeffeae (Archosauria, Suchia), theropod-like convergance, and the distribution of related taxa. Bulletin of the American Museum of Natural History 302. New York: American Museum of Natural History. 84 pp.

Nesbitt, S., Stocker, M. R., Small, B. J. \& Downs, A. 2009a. The osteology and relationships of Vancleavea campi (Reptilia: Archosauriformes). Zoological Journal of the Linnean Society 157 (4), 814-64.

Nesbitt, S. J., Smith, N. D., Irmis, R. B., Turner, A. H., Downs, A. \& Norell, M. A. 2009b. A complete skeleton of a Late Triassic saurischian and the early evolution of dinosaurs. Science 326, 1530-33.

Olsen, P. E. 1986. A 40-million-year lake record of early Mesozoic orbital climatic forcing. Science 234, 842-48.

Olsen, P. E. 1997. Stratigraphic record of the early Mesozoic breakup of Pangea in the Laurasia-Gondwana rift system. Annual Reviews of Earth and Planetary Science 25, 337-401.

Olsen, P. E. 2010. Fossil great lakes of the Newark Supergroup30 years later. In Benimoff, A. I. (ed.) Field Trip Guidebook, New York State Geological Association, 83rd Annual Meeting, 101-62. College of Staten Island: New York State Geological Association.

Olsen, P. E., Shubin, N. H. \& Anders, P. E. 1987. New Early Jurassic tetrapod assemblages constrain Triassic-Jurassic tetrapod extinction event. Science 237, 1025-29.

Olsen, P. E., Kent, D. V., Cornet, B., Witte, W. K. \& Schlische, R. W. 1996a. High-resolution stratigraphy of the Newark rift basin (Early Mesozoic, Eastern North America). Geological Society of America Bulletin 108 (1), 40-77.

Olsen P. E., Schlische R. W. \& Fedosh, M. S. 1996b. 580 kyr duration of the Early Jurassic flood basalt event in eastern North America estimated using Milankovitch cyclostratigraphy. In Morales, M. (ed.) The Continental Jurassic. Museum of Northern Arizona Bulletin 60, 11-22. Flagstaff: Museum of Northern Arizona Press.

Olsen, P. E., Kent, D. V., Fowell, S. J., Schlische, R. W., Withjack, M. O. \& LeTourneau, P. M. 2000. Implications of a comparison of the stratigraphy and depositional environments of the Argana (Morocco) and Fundy (Nova Scotia, Canada) Permian-Jurassic basins. In Oujidi, M. \& Et-Touhami, M. (eds) Le Permien et le Trias du Maroc: Actes de la Premiere Réunion du Groupe Marocain du Permien et du Trias, 165-83. Oujda, Morocco: Hilal Impression.

Olsen, P. E., Kent, D. V., Sues, H.-D., Koeberl, C., Huber, H., Montanari, A., Rainforth, E. C., Fowell, S. J., Szajna, M. J. \& Hartline, B. W. 2002a. Ascent of dinosaurs linked to an iridium anomaly at the Triassic-Jurassic boundary. Science 296, 1305-07.

Olsen, P. E., Kent, D. V. \& LeTourneau, P. M. 2002b. Stratigraphy and age of the Early Jurassic Portland Formation of Connecticut and Massachusetts: a contribution to the time scale of the Early Jurassic. Geological Society of America, Abstracts with Programs 34 (2), A-61.

Olsen, P. E., Koeberl, C., Huber, H., Montanari, A., Fowell, S. J., Et-Touhami, M. \& Kent, D. V. 2002c. The continental TriassicJurassic boundary in central Pangea: recent progress and discussion of an Ir anomaly, In Koerberl, C. \& MacLeod, K. G. (eds) Catastrophic Events and Mass Extinctions: Impacts and Beyond. Geological Society of America, Special Paper 356, 505-22. Boulder, Colorado \& Lawrence, Kansas: Geological Society of America \& University of Kansas Press.

Olsen, P. E., Kent, D. V., Et-Touhami, M. \& Puffer, J. H. 2003. Cyclo-, magneto-, and bio-stratigraphic constraints on the duration of the CAMP event and its relationship to the TriassicJurassic boundary. In Hames, W. E., McHone, J. G., Renne, P. R. \& Ruppel, C. (eds) The Central Atlantic Magmatic Province: Insights From Fragments of Pangea. Geophysical Monograph Series 136, 7-32. Washington, DC: American Geophysical Union.

Olsen, P. E. \& Flynn, J. 1989. Field guide to the vertebrate paleontology of Late Triassic rocks in the southwestern Newark Basin (Newark Supergroup, New Jersey and Pennsylvania). The Mosasaur 4, 1-35.

Olsen, P. E. \& Galton, P. M. 1977. Triassic-Jurassic tetrapod extinctions: are they real? Science 197, 983-86.

Olsen, P. E. \& Galton, P. M. 1984. A review of the reptile and amphibian assemblages from the Stormberg of southern Africa, 
with special emphasis on the footprints and the age of the Stormberg. Palaeontologia Africana 25, 92-110.

Olsen, P. E. \& Kent, D. V. 1996. Milankovitch climate forcing in the tropics of Pangea during the Late Triassic. Palaeogeography, Palaeoclimatology, Palaeoecology 122, 1-26.

Olsen, P. E. \& Kent, D. V. 1999. Long-period Milankovitch cycles from the Late Triassic and Early Jurassic of eastern North America and their implications for the calibration of the early Mesozoic time scale and the long-term behavior of the planets. Philosophical Transactions of the Royal Society A 357, 1761-87.

Olsen, P. E. \& Rainforth, E. C. 2003. The Early Jurassic ornithischian dinosaurian ichnogenus Anomoepus. In LeTourneau, P. M. \& Olsen, P. E. (eds) The Great Rift Valleys of Pangea in Eastern North America, Volume 2: Sedimentology, Stratigraphy, and Paleontology, 314-67. New York: Columbia University Press.

Olsen, P. E. \& Sues, H.-D. 1986. Correlation of the continental Late Triassic and Early Jurassic sediments, and patterns of the Triassic-Jurassic tetrapod transition. In Padian, K. (ed.) The Beginning of the Age of Dinosaurs, Faunal Change Across the Triassic-Jurassic Boundary, 321-51, New York: Cambridge University Press.

Olsen, P. E. \& Whiteside, J. H. 2008. Pre-Quaternary Milankovitch cycles and climate variability. In Gornitz, V. (ed.) Encyclopedia of Paleoclimatology and Ancient Environments. Earth Science Series, 826-35. Dordrecht, the Netherlands: Kluwer Academic Publishers.

Pálfy, J., Mortensen, J. K., Carter, E. S., Smith, P. L., Friedman, R. M. \& Tipper, H. W. 2000. Timing the end-Triassic mass extinction: First on land, then in the sea? Geology 28 (1), 39-42.

Pálfy, J., Parrish, R. R. \& Vörös, A. 2003. Mid-Triassic integrated $\mathrm{U}-\mathrm{Pb}$ geochronology and ammonoid biochronology from the Balaton Highland (Hungary). Journal of the Geological Society, London 160, 271-84.

Pálfy, J. \& Mundil, R. 2006. The age of the Triassic/Jurassic boundary: new data and their implications for the extinction and recovery. Volumina Jurassica 1, 294.

Pálfy, J. \& Smith, P. 2000. Synchrony between Early Jurassic extinction, oceanic anoxic event, and the Karoo-Ferrar flood basalt volcanism. Geology 28 (8) 747-50.

Pankhurst, R. J., Rapela, C. W. \& Marquez, M. J. 1993, Geochronologia y petrogenesis de los granitoides Jurassicos del noreste del Macizo del deseado. XII Congreso Geológico Argentino y II Congreso de Exploración de Hidrocarburos, Mendoza, Actas IV, 134-41. Buenos Aires: Asociación Geológica Argentina.

Parker, W. G. \& Martz, J. W. 2011. The Late Triassic (Norian) Adamanian-Revueltian tetrapod faunal transition in the Chinle Formation of Petrified Forest National Park, Arizona. Earth and Environmental Science Transactions of the Royal Society of Edinburgh 101 (for 2010), 231-60.

Pol, D. 2005. Phylogenetic Relationships of Basal Sauropodomorpha. PhD Thesis, Columbia University, New York. 705 pp.

Pol, D. \& Powell, J. E. 2007. Skull anatomy of Mussaurus patagonicus (Dinosauria: Sauropodomorpha) from the Late Triassic of Patagonia. Historical Biology 19, 125-44.

Puffer, J. H., Block, K. A. \& Steiner, J. C. 2009. Transmission of flood basalts through a shallow crustal sill and the correlation of sill layers with extrusive flows: The Palisades intrusive system and the basalts of the Newark Basin, New Jersey, USA. The Journal of Geology 117, 139-55.

Ramezani, J., Bowring, S. A., Pringle, M. S., Winslow, F. D., III \& Rasbury, E. T. 2005. The Manicouagan impact melt rock: A proposed standard for the intercalibration of U-Pb and ${ }^{40} \mathrm{Ar} /{ }^{39} \mathrm{Ar}$ isotopic systems. Geochimica et Cosmochimica Acta Supplement 69 (10), A321.

Ramezani, J., Bowring, S. A., Fastovsky, D. E. \& Hoke, G. D. 2009. $\mathrm{U}-\mathrm{Pb}$ ID-TIMS geochronology of the Late Triassic Chinle Formation, Petrified Forest National Park, Arizona. Geological Society of America Abstracts with Programs 41 (7), 421.

Ramezani, J., Fastovsky, D. E., Bowring, S. A. \& Hoke, G. D. 2010. Depositional history of the Late Triassic Chinle fluvial system at the Petrified Forest National Park: U-Pb geochronology, regional correlation and insights into early dinosaur evolution. American Geophysical Union, Fall Meeting 2010, Abstract \# V31A-2313.

Rampino, M. R. \& Stothers, R. B. 1988. Flood basalt volcanism during the past 250 million years. Science 241, 663-68

Rasbury, E. T., DeWet, C. B. \& Nienstedt, J. 2003. U-Pb age of stromatolite cacite from the Triassic Passaic Formation of the Newark Basin. Geological Society of America, Abstracts with Programs 37 (7), 508.

Ratcliffe, N. M. 1988. Reinterpretation of the relationships of the western extension of the Palisades sill to the lava flows at
Ladentown, New York, based on new core data. US Geological Survey Bulletin 1776, 113-35.

Rayfield, E. J., Barrett, P. M., McDonnell, R. A. \& Willis, K. J. 2005. A Geographical Information System (GIS) study of Triassic vertebrate biochronology. Geological Magazine 142 (4), 327-54.

Rayfield, E. J., Barrett, P. M. \& Milner, A. R. 2009. Utility and Validity of Middle and Late Triassic 'Land Vertebrate Faunachrons'. Journal of Vertebrate Paleontology 29 (1), 80-87.

Riggs, N. R., Lehman, T. M., Gehrels, G. E. \& Dickinson, W. R. 1996. Detrital zircon link between headwaters and terminus of the Upper Triassic Chinle-Dockum paleoriver system. Science 273, $97-100$.

Riley, T. R., Millar, I. L., Watkeys, M. K., Curtis, M. L., Leat, P. T., Klausen, M. B. \& Fanning, C. M. 2004. U-Pb zircon (SHRIMP) ages for the Lebombo rhyolites, South Africa: refining the duration of Karoo volcanism. Journal of the Geological Society, London 161 (4), 547-50.

Rogers, R. R., Swisher III, C. C., Sereno, P. C., Monetta, A. M., Forster, C. A. \& Martínez, R. N. 1993. The Ischigualasto tetrapod assemblage, late Triassic, Argentina, and ${ }^{40} \mathrm{Ar} /{ }^{39} \mathrm{Ar}$ dating of dinosaur origins. Science 260, 794-97.

Roland, D. L. \& Bottjer, D. J. 2001. Biotic Recovery from the End-Permian Mass Extinction: Behavior of the inarticulate brachiopod Lingula as a disaster taxon. Palaios 16, 95-101.

Ruhl, M., Kürschner, W. M. \& Krystyn, L. 2009. Triassic-Jurassic organic carbon isotope stratigraphy of key sections in the western Tethys realm (Austria). Earth and Planetary Science Letters 281, $169-87$.

Ruhl, M., Deenen, M. H. L., Abels, H. A., Bonis, N. R., Krijgsman, W. \& Kürschner, W. M. 2010. Astronomical constraints on the duration of the early Jurassic Hettangian stage and recovery rates following the end-Triassic mass extinction (St. Audrie's Bay/East Quantoxhead, UK). Earth and Planetary Science Letters 295, $262-76$.

Savage, N. M. \& Gehrels, G. E. 1987. Early Devonian and Late Triassic conodonts from Annette and Hotspur islands, southeastern Alaska. Geological Society of America, Abstracts with Programs 19 (6), 446.

Schaltegger, U., Guex, J., Bartolini, A., Schoene, B. \& Ovtcharova, M. 2008. Precise U-Pb age constraints for end-Triassic mass extinction, its correlation to volcanism and Hettangian postextinction recovery. Earth and Planetary Science Letters 267, 266-75.

Schlische, R. W. 2003. Progress in understanding the structural geology, basin evolution, and tectonic history of the eastern North American rift system. In LeTourneau, P. M. \& Olsen, P. E. (eds) The Great Rift Valleys of Pangea in Eastern North America, Volume 1: Tectonics, Structure and Volcanism, 21-64. New York: Columbia University Press.

Schoene, B., Guex, J., Bartolini, A., Schaltegger, U. \& Blackburn, T. J. 2010. A correlation between the Triassic-Jurassic boundary mass extinction and flood basalt eruption at the $100 \mathrm{ka}-$ level using ID-TIMS U/Pb zircon geochronology. Geology 38, 387-90.

Schultz, C. L. 2005. Biostratigraphy of the non-marine Triassic: is a global correlation based on tetrapod faunas possible? In Koutsoukos, E. A. M. (ed.) Applied Stratigraphy, 123-45. Dordrecht, The Netherlands: Springer.

Shipman, T. C. 2004. Links between sediment accumulation rates and the development of alluvial architecture: Triassic Ischigualasto Formation, Northwestern Argentina. Unpublished PhD Thesis, University of Arizona, Tucson. $184 \mathrm{pp}$.

Simms, M. J. 2007. Uniquely extensive soft-sediment deformation in the Rhaetian of the UK: Evidence for earthquake or impact? Palaeogeography, Palaeoclimatology, Palaeoecology 244, 407-23.

Smith, R. \& Kitching, J. 1997. Sedimentology and vertebrate taphonomy of the Tritylodon Acme Zone: a reworked palaeosol in the Lower Jurassic Elliot Formation, Karoo Supergroup, South Africa. Palaeogeography, Palaeoclimatology, Palaeoecology 131, 29-50

Smith, R. C., Berkheiser, S. W., Barnes, J. H. \& Hoff, D. T. 1988. Strange clay baffles geologists. Pennsylvania Geology 19, 8-13.

Steiner, M. B. \& Lucas, S. G. 2000. Paleomagnetism of the Late Triassic Petrified Forest Formation, Chinle Group, western United States: Further evidence of 'large' rotation of the Colorado Plateau. Journal of Geophysical Research 105 (B11), $25,791-808$

Sutter, J. F. 1988. Innovative approaches to the dating of igneous events in the early Mesozoic basins of the eastern United States. US Geological Survey Bulletin 1776, 194-200.

Tabor, N. J., Montanez, I. P., Kelso, K. A., Currie, B., Shipman, T. C. \& Colombi, C. 2006. A Late Triassic soil catena; landscape and climate controls on paleosol morphology and chemistry across 
the Carnian-age Ischigualasto-Villa Union Basin, northwestern Argentina. Geological Society of America Special Paper 416, $17-41$.

Tackett, L. S., Bottjer, David J., Sheehan, P. M. \& Fastovsky, D. 2009. Comparative effects of two large bolide impact events: Chicxulub and Manicouagan. Geological Society of America Abstracts with Programs 41 (7), 240.

Tanner, L. H., Lucas, S. G. \& Chapman, M. G. 2004. Assessing the record and causes of Late Triassic extinctions. Earth-Science Reviews 65, 103-39.

Tims, B. V. 2009. A revision of the Australian endemic clam shrimp genus Limnadopsis Spencer \& Hall (Crustacea: Branchiopoda: Spinicaudata: Limnadiidae). Records of the Australian Museum 61, 49-72.

Tozer, E. T. 1979. Latest Triassic ammonoid faunas and biochronology, western Canada. Geological Survey of Canada, Paper 79-1B, $127-35$.

Traverse, A. 2007. Paleopalynology. Topics in Geobiology 28 Dordrecht, The Netherlands: Springer. $813 \mathrm{pp}$.

Upchurch, P., Barrett, P. M. \& Galton, P. M. 2007. A phylogenetic analysis of basal sauropodomorph relationships: implications for the origin of sauropod dinosaurs. In Barrett, P. M. \& Batten, D. J. (eds) Evolution and Palaeobiology of early sauropodomorph dinosaurs. Special Papers in Palaeontology 77, 57-90. London: The Palaeontological Association.

van Houten, F. B. 1962. Cyclic sedimentation and the origin of analcime-rich upper Triassic Lockatong Formation, west-central New Jersey and adjacent Pennsylvania. American Journal of Science 260, 561-76.

van Soest, M. C., Wartho, J.-A., Monteleone, B. D., Hodges, K. V., Koeberl, C., Schmieder, M., Buchner, E. J., Spray, G., Bezys, R. K. \& Reimold, W. U. 2009. (U-Th)/He dating of single zircon and apatite crystals - a new tool for dating terrestrial impact structures. 40th Lunar and Planetary Science Conference (2009), Abstract 2041

van Veen, P. M. 1995. Time calibration of Triassic/Jurassic microfloral turnover, eastern North America-Comment. Tectonophysics 245, 93-95.

Varela, R., Pezzuchi, H., Genini, A. \& Zubia, M. 1991. Dataciones de rocas magmaticas en el Jurasico Inferior del nordeste del Macizo del Deseado, Santa Cruz. Revista de la Asociacion Geologica Argentina 46, 257-62.

Visscher, H. 1992. The new STS Triassic stage nomenclature. Albertiana 10, 1-2.
Walkden, G. \& Parker, J. 2008. The biotic effects of large bolide impacts: size versus time and place. International Journal of Astrobiology 7, 209-15.

Walker, J. \& Geissman, J. 2009. GSA Geologic Time Scale 2009. GSA Today 19 (4). doi: 10.1130/1052-5173-19.4-5.60.

Wang, Z. S., Rasbury, E. T., Hanson, G. N. \& Meyers, W. J. 1998. Using the U-Pb system of calcretes to date the time of sedimentation of clastic sedimentary rocks. Geochimica et Cosmochimica Acta 62, 2823-35.

Whiteside, J. H., Olsen, P. E., Kent, D. V., Fowell, S. J. \& Et-Touhami, M. 2007. Synchrony between the CAMP and the Triassic-Jurassic mass-extinction event? Palaeogeography, Palaeoclimatology, Palaeoecology 244, 345-67.

Whiteside, J. H., Olsen, P. E., Eglinton, T., Montluçon, D., Brookfield, M. E. \& Sambrotto, R. N. 2010. Compound-specific carbon isotopes from Earth's largest flood basalt province directly link eruptions to the end-Triassic mass extinction. Proceedings of the National Academy of Sciences USA 107, 6721-25.

Witzmann, F. \& Gassner, T. 2008. Metoposaurid and mastodonsaurid stereospondyls from the Triassic-Jurassic boundary of Portugal. Alcheringa 32 (1), 37-51.

Woody, D. T. 2006. Revised stratigraphy of the lower Chinle Formation (Upper Triassic) of Petrified Forest National Park, Arizona. In Parker, W. G., Ash, S. R. \& Irmis, R. B. (eds) A century of research at Petrified Forest National Park 1906-2006: geology and paleontology. Museum of Northern Arizona Bulletin 62, 17-45. Flagstaff: Museum of Northern Arizona Press.

Yang, Z., Moreau, M.-G., Bucher, H., Dommergues, J.-L. \& Trouiller, A. 1996. Hettangian and Sinemurian magnetostratigraphy from the Paris Basin. Journal of Geophysical Research 101, $8025-42$.

Yates, A. M. 2005. The skull of the Triassic sauropodomorph, Melanorosaurus readi, from South Africa and the definition of Sauropoda. Journal of Vertebrate Paleontology 25 (supplement 3), 132A.

Yates, A. M. 2007. The first complete skull of the Triassic dinosaur Melanorosaurus Haughton (Sauropodomorpha: Anchisauria). In Barrett, P. M. \& Batten, D. J. (eds) Evolution and palaeobiology of early sauropodomorph dinosaurs. Special Papers in Palaeontology 77, 9-55. London: The Palaeontological Association.

Yates, A. M., Bonnan, M. F., Noveling, J., Chinsamy, A. \& Blackbeard, M. G. 2009. A new transitional sauropodomorph dinosaur from the Early Jurassic of South Africa and the evolution of sauropod feeding and quadrupedalism. Proceedings of the Royal Society B 277, 787-94. 